Andrews University

Digital Commons @ Andrews University

Professional Dissertations DMin

Graduate Research

2000

\title{
A Church Growth Study of Three Churches in Kottayam
}

Robinson Stephenson

Andrews University

Follow this and additional works at: https://digitalcommons.andrews.edu/dmin

Part of the Practical Theology Commons

\section{Recommended Citation}

Stephenson, Robinson, "A Church Growth Study of Three Churches in Kottayam" (2000). Professional Dissertations DMin. 668.

https:dx.doi.org/10.32597/dmin/668

https://digitalcommons.andrews.edu/dmin/668

This Project Report is brought to you for free and open access by the Graduate Research at Digital Commons @ Andrews University. It has been accepted for inclusion in Professional Dissertations DMin by an authorized administrator of Digital Commons @ Andrews University. For more information, please contact repository@andrews.edu. 


\section{ABSTRACT}

\section{A CHURCH GROWTH STUDY OF THREE CHURCHES}

IN KOTTAYAM

by

Robinson Stephenson

Adviser: Gordon Christo 


\title{
ABSTRACT OF GRADUATE STUDENT RESEARCH
}

Dissertation

\author{
Andrews University
}

Seventh-day Adventist Theological Seminary

\section{Title: A CHURCH GROWTH STUDY OF THREE CHURCHES IN KOTTAYAM}

Name of researcher: R. Stephenson

Name and degree of faculty adviser: Dr. Gordon Christo, Ph.D.

Date completed: August 2000

\section{Problem}

Many of the churches in the North Kerala Section have been stagnant for years. In some churches over 50 percent of the members are inactive. This study analyzes the hindrances to the growth of three churches in the Kottayam District and suggests a strategy for church growth.

\section{Method}

The theological, historical, missiological, and practical dimensions of church growth were examined. A church growth approach was used which included an analysis of the factors involved in the growth and decline of three SDA churches in the Kottayam district. The growth patterns of three churches over the past ten years were analyzed. Appropriate growth strategies were then designed. 


\section{Results}

The growth analysis found that one church grew because of its inspiring worship services and an active healing ministry. For ten years the pastor has not been transferred. Each member contributes to the unity of the church. The youth and the lay members take active part in witnessing.

In the other two churches lay members were not interested in outreach programs due to lack of vision and insufficient training. Moreover, there was a lack of visitation, as well as of love and fellowship in the church. The worship services were monotonous and there was lack of spirituality in the church. The members felt that the programs of the church did not meet their needs.

\section{Conclusion}

It was concluded that a ten-day lay training program would help to train the laity to do the church activities as well as outreach activities more effectively. The introduction of a new worship format appropriate to the local situation will meet the needs of the worshippers. Prayer ministry and cell groups will make the church a praying church. Church growth seminars will help in vision building, ministry skill enhancement, and developing strategic thinking. Health seminars will help to find receptive people and to present the gospel without prejudice in new areas. 
Andrews University

Seventh-day Adventist Theological Seminary

\title{
A CHURCH GROWTH STUDY OF THREE CHURCHES
}

IN KOTTAYAM

\author{
A Dissertation \\ Presented in Partial Fulfilment \\ of the Requirements for the Degree \\ Doctor of Ministry
}

by

Robinson Stephenson

September 2000 


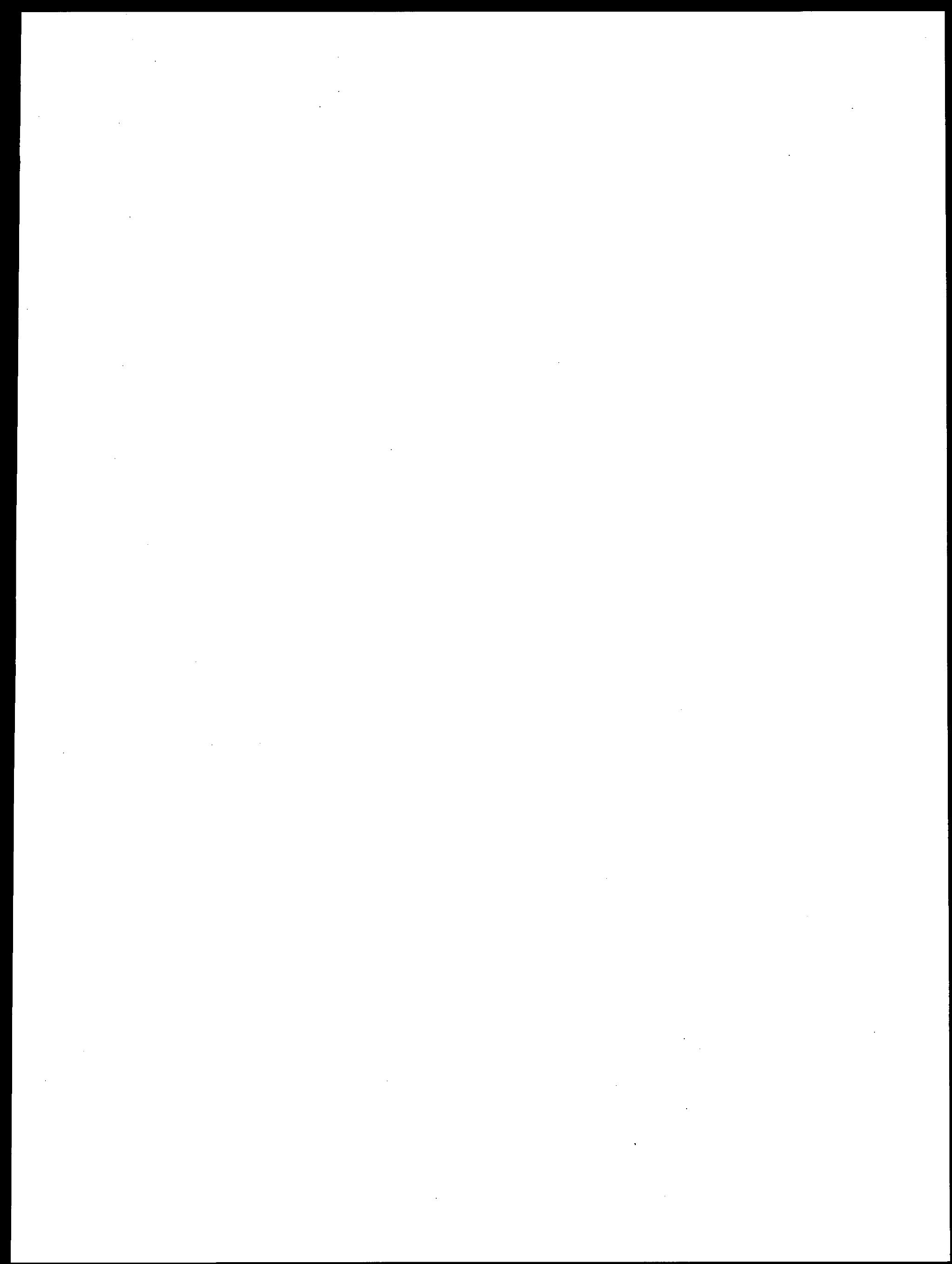




\section{A CHURCH GROWTH STUDY OF THREE CHURCHES}

IN KOTTAYAM

A dissertation

presented in partial fulfillment of the requirements for the degree

Doctor of Ministry

by

Robinson Stephenson

APPRONAL BY THE COMMTTTEE:

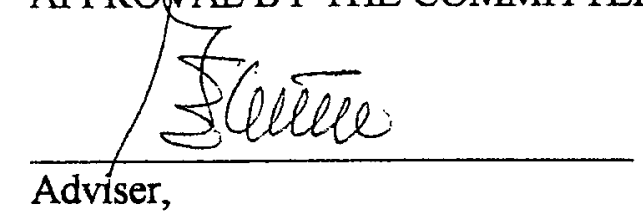

Gordon Christo

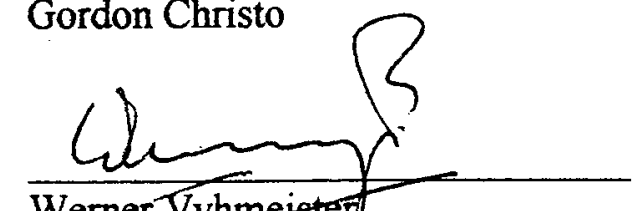

Werner Vyhmeister

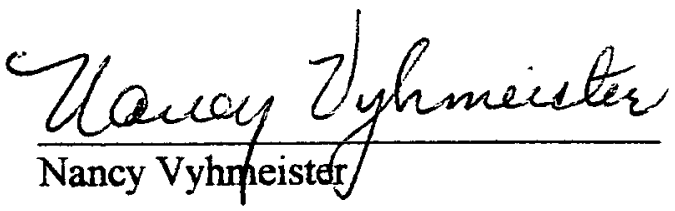

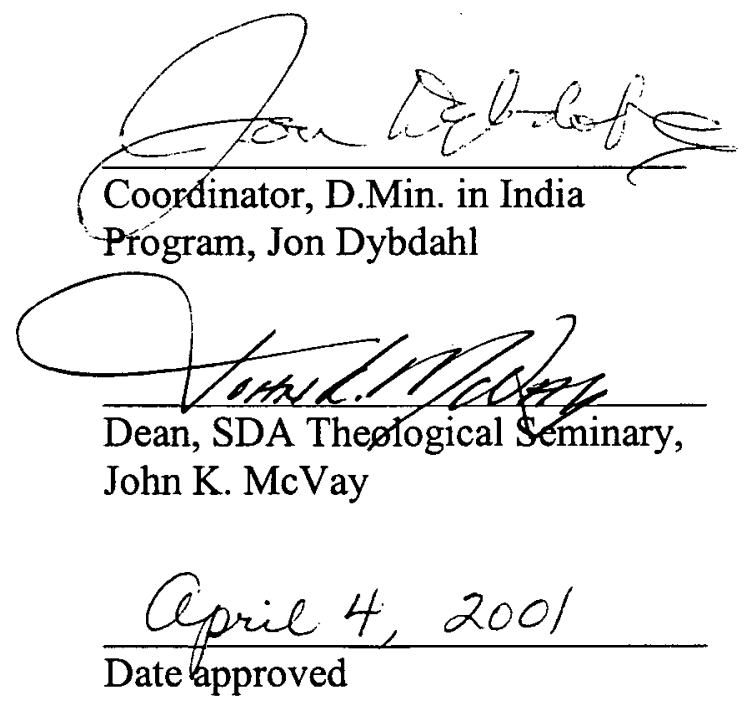




\section{TABLE OF CONTENTS}

LIST OF TABLES $\ldots \ldots \ldots \ldots \ldots \ldots \ldots \ldots \ldots \ldots \ldots \ldots \ldots \ldots$ vii

LIST OF FIGURES $\ldots \ldots \ldots \ldots \ldots \ldots \ldots \ldots \ldots \ldots \ldots \ldots$ vii

ACKNOWLEDGMENTS $\ldots \ldots \ldots \ldots \ldots \ldots \ldots \ldots \ldots \ldots \ldots \ldots$ viii

Chapter

I. INTRODUCTION $\ldots \ldots \ldots \ldots \ldots \ldots \ldots \ldots \ldots \ldots \ldots \ldots \ldots \ldots$

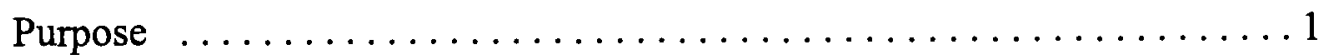

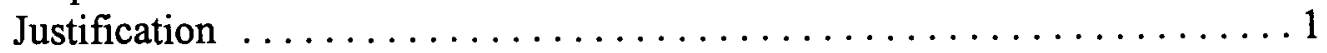

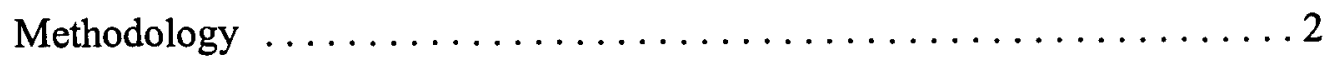

II. CHURCH GROWTH IN THE BIBLE AND

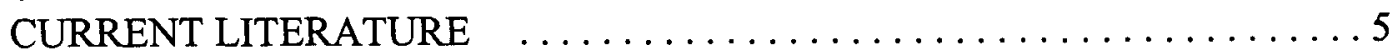

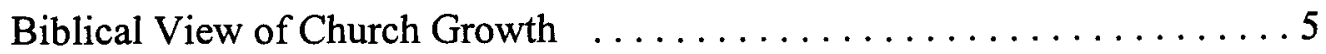

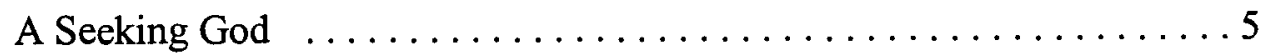

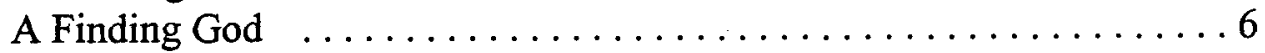

God's Passion to Find $\ldots \ldots \ldots \ldots \ldots \ldots \ldots \ldots \ldots \ldots$

The Gospel Commission . . . . . . . . . . . . . . . . 9

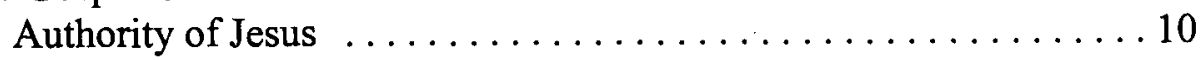

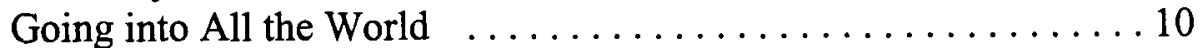

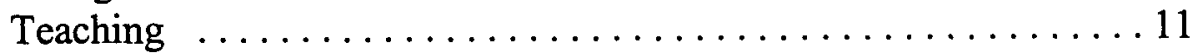

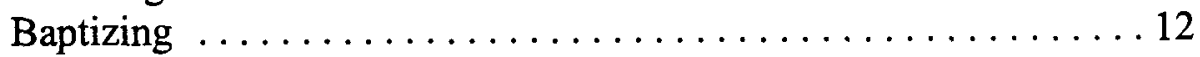

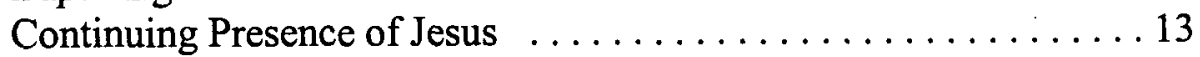

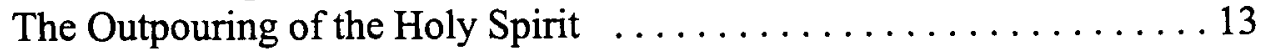

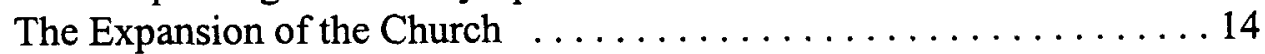

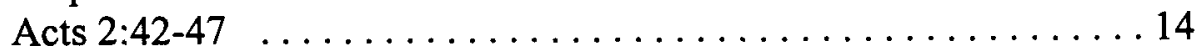

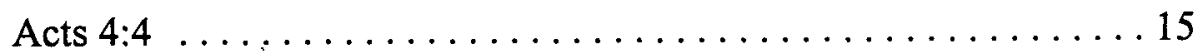

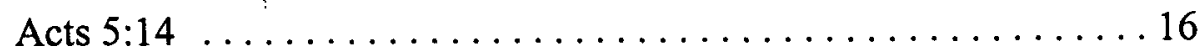

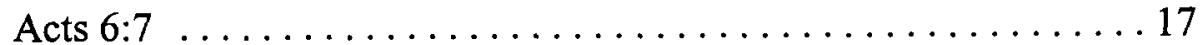

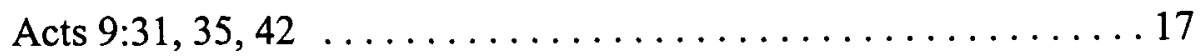

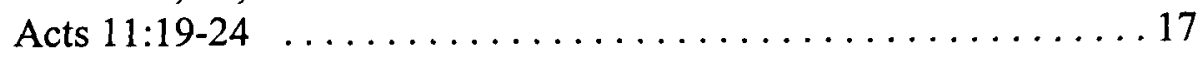

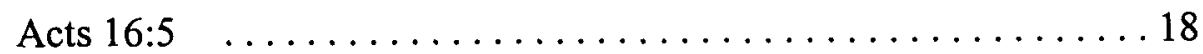

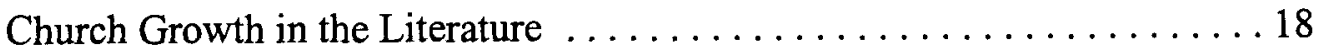


General Principles

Schwarz's Eight Essential Qualities of Healthy

Churches

Zachariah's Seven Growth Principles $\ldots \ldots \ldots \ldots \ldots \ldots \ldots$

Specific Principles for Kottayam $\ldots \ldots \ldots \ldots \ldots \ldots \ldots \ldots \ldots \ldots \ldots \ldots$

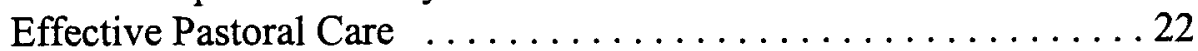

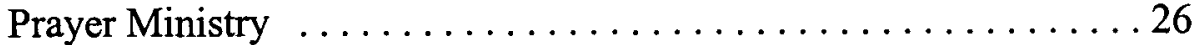

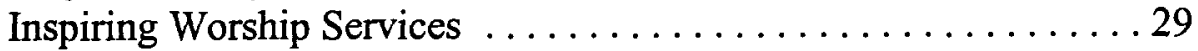

People Group Approach $\ldots \ldots \ldots \ldots \ldots \ldots \ldots \ldots \ldots \ldots \ldots \ldots$

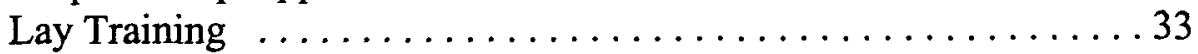

Small Group Ministry $\ldots \ldots \ldots \ldots \ldots \ldots \ldots \ldots \ldots \ldots \ldots . \ldots \ldots$

Revival ............................. 45

III. DESCRIPTION OF KOTTAYAM $\ldots \ldots \ldots \ldots \ldots \ldots \ldots \ldots \ldots \ldots \ldots$

History ..................................... 49

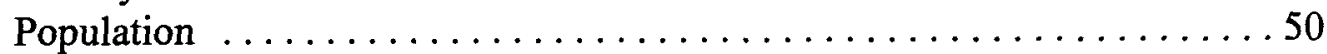

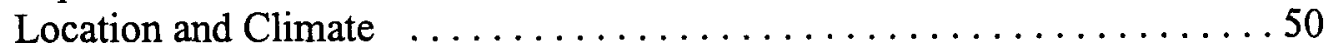

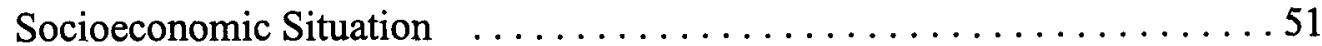

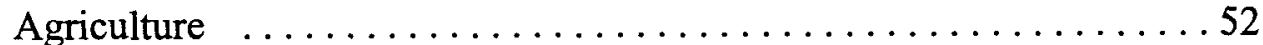

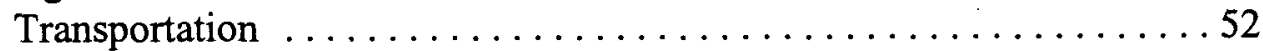

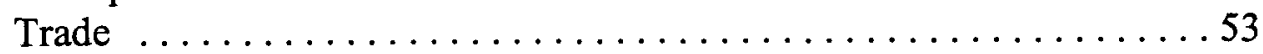

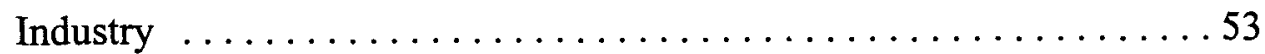

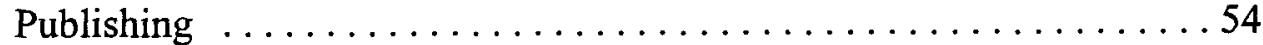

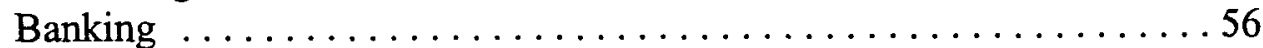

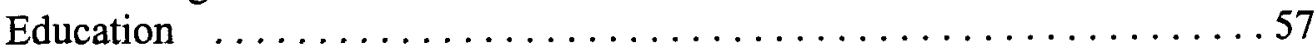

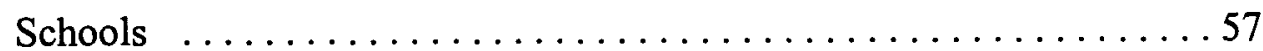

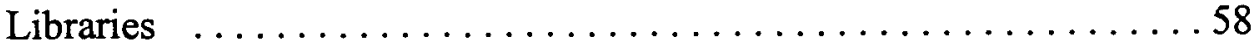

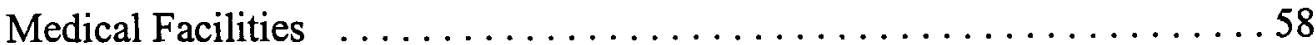

Culture ...................................... 58

Tourism ..................................... 59

Marriage Customs and Rituals $\ldots \ldots \ldots \ldots \ldots \ldots \ldots \ldots \ldots . \ldots . \ldots . \ldots 59$

Dance ....................................60

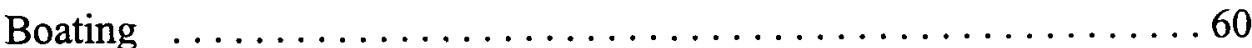

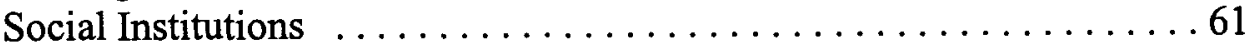

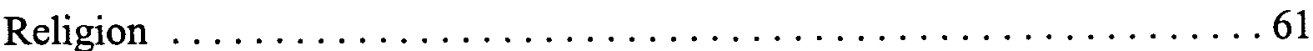

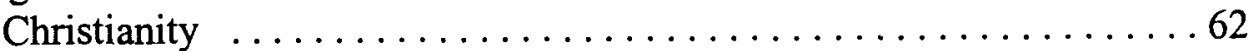

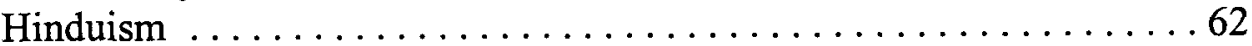

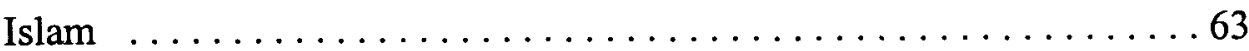

IV. DESCRIPTION OF THREE SDA CHURCHES OF

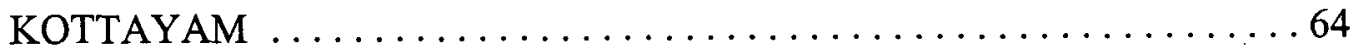

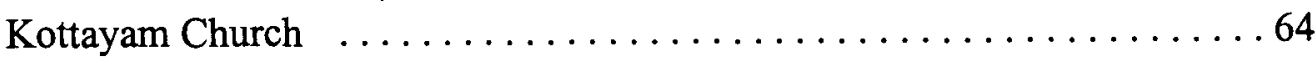

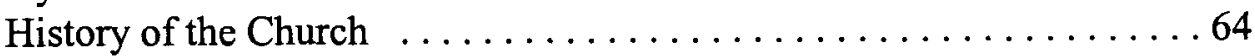




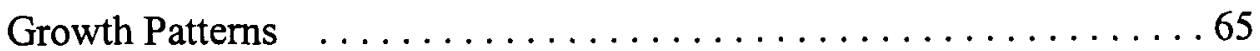

Factors Contributing to the Growth $\ldots \ldots \ldots \ldots \ldots \ldots \ldots \ldots \ldots \ldots$

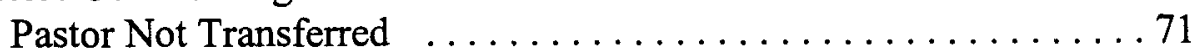

Inspiring Worship Services $\ldots \ldots \ldots \ldots \ldots \ldots \ldots \ldots \ldots \ldots$

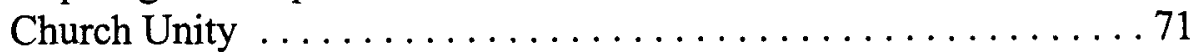

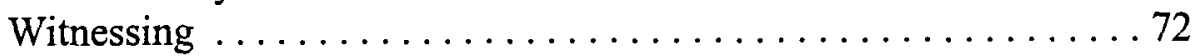

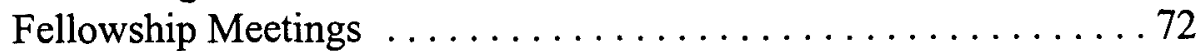

Vacation Bible School ....................... 72

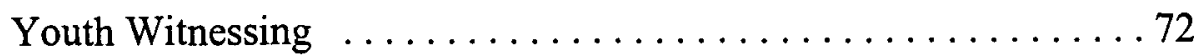

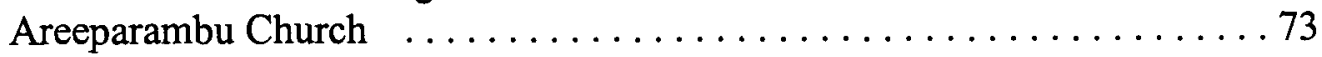

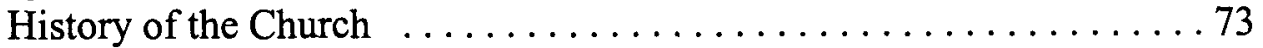

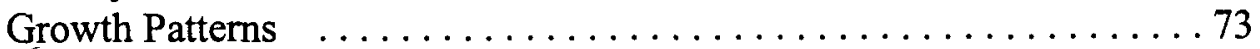

Proposed Growth Strategies $\ldots \ldots \ldots \ldots \ldots \ldots \ldots \ldots \ldots \ldots$

Motivation of the Members $\ldots \ldots \ldots \ldots \ldots \ldots \ldots \ldots$

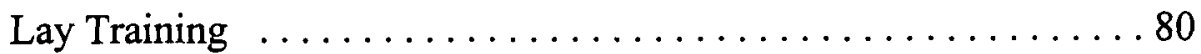

Visiting Inactive Members $\ldots \ldots \ldots \ldots \ldots \ldots \ldots \ldots$

Revival Meetings $\ldots \ldots \ldots \ldots \ldots \ldots \ldots \ldots \ldots \ldots \ldots$

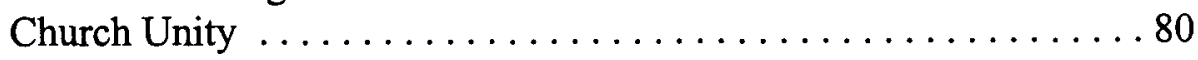

Kurichy Church $\ldots \ldots \ldots \ldots \ldots \ldots \ldots \ldots \ldots \ldots \ldots \ldots \ldots \ldots \ldots \ldots \ldots \ldots \ldots$

History of the Church $\ldots \ldots \ldots \ldots \ldots \ldots \ldots \ldots \ldots \ldots \ldots \ldots . \ldots \ldots 1$

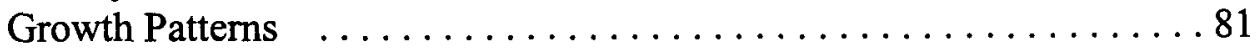

Strategies for Growth $\ldots \ldots \ldots \ldots \ldots \ldots \ldots \ldots \ldots \ldots \ldots \ldots . \ldots \ldots 78$

Inspiring Worship Services $\ldots \ldots \ldots \ldots \ldots \ldots \ldots \ldots$. . . . 87

Revival Meetings $\ldots \ldots \ldots \ldots \ldots \ldots \ldots \ldots \ldots \ldots \ldots$

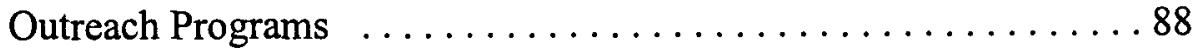

Small-Group Prayer Ministry $\ldots \ldots \ldots \ldots \ldots \ldots \ldots . \ldots 88$

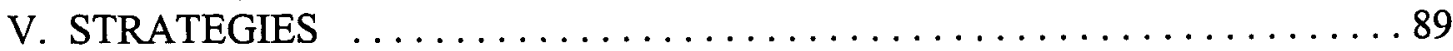

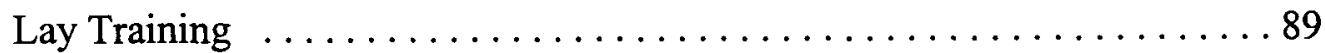

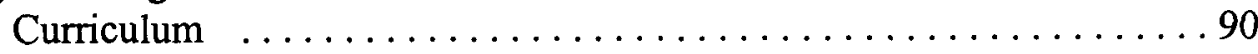

General Program $\ldots \ldots \ldots \ldots \ldots \ldots \ldots \ldots \ldots \ldots \ldots \ldots \ldots \ldots$

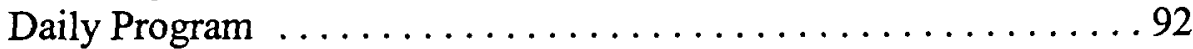

Selection of Trainees $\ldots \ldots \ldots \ldots \ldots \ldots \ldots \ldots \ldots \ldots \ldots, \ldots 2$

Resources .................................994

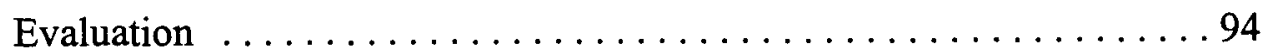

Worship Renewal .............................. 95

New Worship Format $\ldots \ldots \ldots \ldots \ldots \ldots \ldots \ldots \ldots \ldots . \ldots . \ldots . \ldots . \ldots 95$

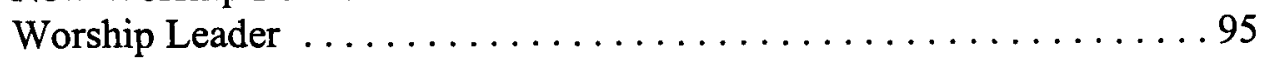

Music ....................................96

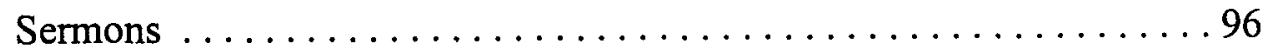

Announcements ...............................97

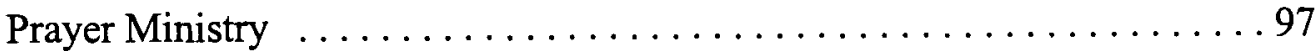

Cell Groups $\ldots \ldots \ldots \ldots \ldots \ldots \ldots \ldots \ldots \ldots \ldots \ldots \ldots \ldots \ldots . \ldots \ldots$

How to Start Cell Groups $\ldots \ldots \ldots \ldots \ldots \ldots \ldots \ldots \ldots$ 
How to Continue Cell Groups . . . . . . . . . . . . . . 101

Health Seminars . . . . . . . . . . . . . . . . . . . . . . . 102

Church Growth Seminars $\ldots . \ldots \ldots \ldots \ldots \ldots \ldots$. . . . . . . . . . 104

Focus ................................... 104

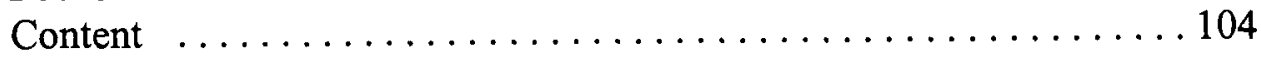

VI. SUMMARY, CONCLUSION, AND RECOMMENDATIONS $\ldots \ldots \ldots \ldots$

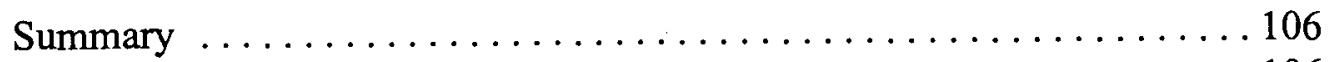

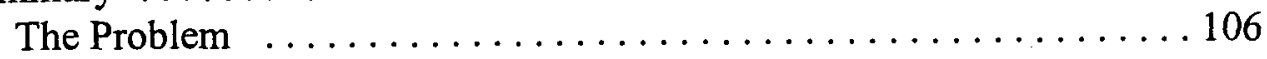

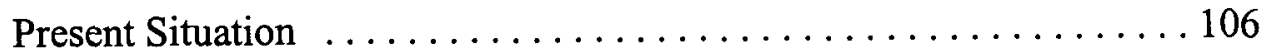

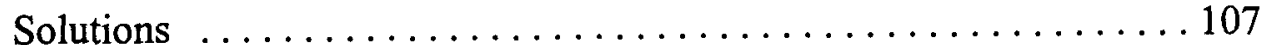

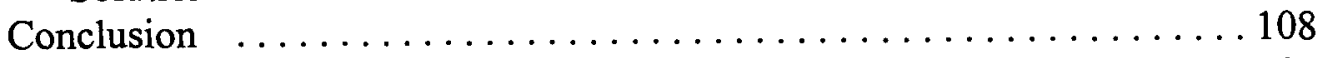

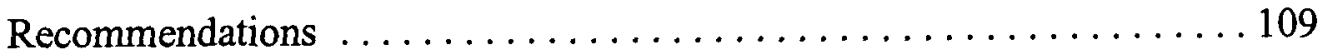

To the North Kerala Section $\ldots \ldots \ldots \ldots \ldots \ldots . \ldots \ldots$

To the Local Churches . . . . . . . . . . . . . . . . . . . . . . . . . . 109

To the Southern Asia Division . . . . . . . . . . . . . . 110

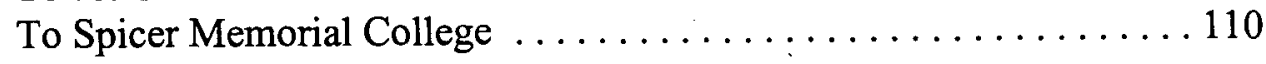

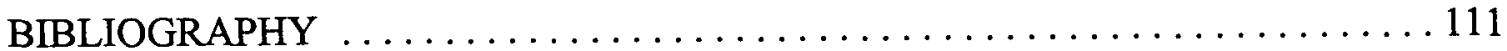

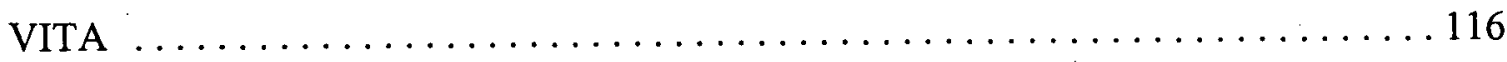




\section{LIST OF TABLES}

1. Malayala Manorama Publications $\ldots \ldots \ldots \ldots \ldots \ldots \ldots \ldots \ldots \ldots \ldots$

2. Christian Churches in the Kottayam District $\ldots \ldots \ldots \ldots \ldots \ldots \ldots \ldots \ldots$

3. Membership Statistics, 1987-1997, Kottayam Church .............66

4. Membership Statistics, 1987-1997, Areeparambu Church . . . . . . . . . . 74

5. Membership Statistics, $1987-1997$, Kurichy Church $\ldots \ldots \ldots \ldots \ldots \ldots$

6. A Proposed Program Schedule $\ldots \ldots \ldots \ldots \ldots \ldots \ldots \ldots \ldots \ldots \ldots$

\section{LIST OF FIGURES}

1. Composite Membership, 1987-1997, SDA Church, Kottayam . . . . . . . . 67

2. Decadal Growth Rate, SDA Church, Kottayam $\ldots \ldots \ldots \ldots \ldots \ldots$

3. Annual Growth Rate, SDA Church, Kottayam . . . . . . . . . . . . . . 69

4. Faith Projection, SDA Church, Kottayam $\ldots \ldots \ldots \ldots \ldots \ldots \ldots$

5. Composite Membership Growth, Areeparambu Church $\ldots \ldots \ldots \ldots \ldots \ldots 75$

6. Decadal Growth Rate, SDA Church, Areeparambu $\ldots \ldots \ldots \ldots \ldots \ldots$

7. Annual Growth Rate, SDA Church, Areeparambu $\ldots \ldots \ldots \ldots \ldots \ldots \ldots$

8. Faith Projection, SDA Church, Areeparambu $\ldots \ldots \ldots \ldots \ldots \ldots \ldots$

9. Membership Growth Rate of the Kurichy Church $\ldots \ldots \ldots \ldots \ldots \ldots$

10. Decadal Growth Rate at Kurichy Church, $1987-1997$. . . . . . . . . . . 84

11. Annual Growth Rate of the Kurichy Church, $1987-1997 \quad \ldots \ldots \ldots \ldots \ldots \ldots$

12. Faith Projection, Kurichy Church $\ldots \ldots \ldots \ldots \ldots \ldots \ldots \ldots \ldots \ldots \ldots \ldots \ldots \ldots \ldots \ldots \ldots$ 


\section{ACKNOWLEDGMENTS}

As the process of writing this dissertation comes to a close, it becomes clear that I am indebted to more people than I could possibly mention. I am extremely thankful to my God for His marvelous guidance and protection and all His bountiful blessings bestowed upon me in spite of all problems, difficulties, and disturbances, helping me to complete this dissertation.

It is indeed my pleasure to acknowledge my indebtedness to my dissertation committee chairman, Dr. Gordon Christo, for his sustained interest and guidance in this dissertation work.

I would like to thank Dr. Prema Gaikwad for her suggestions and encouragement. I would like to thank Dr. Bruce Bauer and Mrs. Linda Bauer for their help and suggestions in correcting the format of this dissertation.

I am also indebted to Dr. John Dybdahl for his valuable suggestions and help in the correction work of this dissertation; Dr. Nancy Vyhmeister for her guidance in the dissertation work to make it highly standardized and for her motherly concern. I also thank Dr. Werner Vyhmeister for his help in reading and correcting this paper.

I would also like to thank the librarians and other library staff of United Biblical Seminary in Pune, Church Growth Research Centre in Madras, Ishwani Kendra in Pune, and Spicer Memorial College in Pune.

I am also thankful to Ms. Maureen Dkhar for typing this manuscript, for the accurate and neat work done to complete this dissertation. 
My deepest indebtedness is to the Southern Asia Division for the financial support during the last four years of my study program, without which this dissertation would not have been possible. 


\section{CHAPTER I}

\section{INTRODUCTION}

\section{Purpose}

The purpose of this study is to analyze the growth patterns of three churches in Kottayam in the North Kerala Section of the Seventh-day Adventist Church and to develop strategies for their growth.

\section{$\underline{\text { Justification }}$}

While some churches grow, others decline; some churches are healthy and others are sick. Can a pastor influence the growth of the church? Why is there no revival in the church? How can revival be encouraged in the church? Why do some people not attend worship services? While the Pentecostal churches are growing in this area, why do Adventist churches not grow? What are the causes of stagnation and decline? These questions have troubled me as I have looked at the churches in the North Kerala Section. Many of the churches in the North Kerala Section have not grown for many years. In some churches about 50 percent of the members are inactive. For the last twenty-five years in this Section, very little has been done to encourage the growth of the church due to ignorance and many other factors. Quite often non-growth is a curable disease. This study will help to discover the various factors which have caused inactivity and decline. 
The field leadership needs an understanding of the actual situation of the church in order to set goals and to develop new strategies for church growth. The strategy proposed in this study and the recommendations will help to enhance church growth in the Section.

Many of the pastors and the laity-do not have a clear understanding of the principles of church growth, and have not designed appropriate strategies to enhance church growth. Many pastors and laity have lost their vision in this respect. I hope this study will give an insight concerning church growth principles that will suggest possibilities for outreach programs.

The laity should be trained properly for outreach programs. In many churches the pastors do all the work of the church since the laity are not involved. Pastors must learn to delegate responsibilities to the members. The apostolic church grew because of lay participation. It is my burden to conduct training for the laity and hold church growth seminars and workshops in order to enhance church growth.

I chose this topic because of my personal interest in the growth of the church. As a pastor of the North Kerala Section, I am interested in the growth and development of the churches in this part of India. This strategy will be implemented in a few churches and, if successful, can be adopted by other churches.

\section{Methodology}

The theological, historical, missiological, and practical dimensions of church growth were examined. Growth patterns for a ten-year period in three churches in Kottayam were analyzed. Strategies for the three churches were proposed with an 
emphasis on lay training, worship, and prayer.

Chapter 1 introduces this study. Chapter 2 presents church growth principles found in the Bible and in current literature. The Bible presents a seeking and finding God. God is not concerned merely with searching. He is interested in finding lost sheep. Each Christian has a part in fulfilling the gospel commission. The outpouring of the Holy Spirit on the Day of Pentecost helped the Apostolic church grow. The book of Acts provides a detailed account of the growth of the church in the first century.

The last half of chapter 2 deals with general principles recommended by some church growth authors. Schwarz's eight essential qualities of healthy churches and Zachariah's seven growth principles are surveyed. Effective pastoral care, prayer ministry, inspired worship services, a people group approach, lay training, lay participation in outreach, small-group ministries, and revival meetings are discussed as growth principles that could be used in India.

Chapter 3 provides a socioeconomic and cultural description of Kottayam. The three major religions found in Kottayam are discussed, as well as other factors that might affect church growth.

Chapter 4 provides a detailed description of three churches: Kottayam, Areeparambu, and Kurichy; the history, membership growth rates, and faith projections are considered. The chapter also points out factors that have contributed to the growth and decline of the churches.

Chapter 5 suggests a possible strategy for the growth of the churches in the Kottayam District. Suggested programs include ten-day lay training seminars, culturally relevant worship services, and the introduction of prayer seminars to help the churches 
become praying churches. Cell-group ministries, church growth, and health seminars are also discussed in the chapter.

Chapter 6 presents a summary of this study. It also provides the conclusions and recommendations drawn from this research. 


\section{CHAPTER II}

\section{CHURCH GROWTH IN THE BIBLE}

AND CURRENT LITERATURE

Studies have been done by various scholars, theologians, and missiologists regarding church growth. This review of literature seeks to discover what has been found in the writings of general church growth writers, Indian writers, and Adventist writers in the church growth area. However, this study begins with a biblical view of church growth.

\section{Biblical View of Church Growth}

\section{A Seeking God}

The book of Genesis reveals a seeking God who is interested in the benefit of His creation. When Adam and Eve sinned, God came to the garden of Eden seeking the lost couple, taking the initiative in bringing salvation to them (Gen 3:9). God had a concern for the human race. ${ }^{1}$ He called Abraham to be a true representative of humanity and He promised him, "I will make of thee a great nation, and I will bless thee, and make thy name great, and thou shalt be a blessing, and in thee shall all families of the earth be

\footnotetext{
'Roger Hedlund, "Biblical Basis for Church Growth," India Church Growth 1 (1984): 18.
} 
blessed" (Gen 12:2,3). ${ }^{1}$ God wanted to save the entire human race though Abraham.

God wanted the children of Israel to be a missionary people. He wanted to reveal His plan of salvation through them. ${ }^{2}$ He said, "Ye shall be a peculiar treasure unto me above all people, for all the earth is mine. And ye shall be unto me a kingdom of priests, and a holy nation" (Exod 19:5, 6). "For what nation is there so great who hath God so nigh unto them, as the Lord our God is in all things that we call upon him for? And what nation is so great that hath statues and judgments so righteous as all this law, which I set before you this day?" (Deut 4:7, 8). God's mighty acts, the miracles, and the plagues were a witness to the surrounding nations. When they heard about the mighty works of God, they all trembled (Exod 15:13). ${ }^{3}$ He wanted men and women to see the blessing of the people and recognize the living God through them. ${ }^{4}$

\section{A Finding God}

The New Testament presents God, not only as a searching God, but also as a finding God: "For the Son of man is come to seek and save that which was lost" (Luke 19:10). The God of heaven sent Jesus Christ to this world as the greatest missionary. The parables of Luke 15 show God's concern for the lost and His pleasure in finding

${ }^{1}$ Unless otherwise specified all Bible verses are taken from the King James Version.

${ }^{2}$ Hedlund, "Biblical Basis," 18.

${ }^{3} \mathrm{Ibid}$.

4"The Role of Israel in the Old Testament Prophecy," Seventh-day Adventist Bible Commentary (SDABC), ed. Francis D. Nichol, rev. ed. (Washington, D.C.: Review and Herald, 1980), 4:27-28. 
them. ${ }^{1}$ McGavran states, "It is not enough to search for the lost sheep. The master Shepherd is not pleased with a token search, He wants His sheep found. The purpose is not to search, but to find."2

When a sheep is lost, the whole village is on the watch; when they see the lost sheep on the shoulders of the shepherd, there is a shout of joy and of thanksgiving from the whole community. ${ }^{3}$ Jesus draws a picture of God through this parable. "God is as glad when a lost sinner is found, as a shepherd is when a strayed sheep is brought home." Jesus taught the people that God loves all. He loves even the tax collectors and the sinners. As Barclay observes, "Men may give up hope of a sinner, not so God. God loves the folk who never stray away, but in His heart there is the joy of joys when a lost one is found and comes home."

The three parables of Luke 15 emphasized the actual finding of what was lost. The woman did not merely search, but searched until she found the lost coin (Luke 15:8, 9). The shepherd left the ninety-nine to search for the lost sheep and was glad when he found it (Luke 15:6). The waiting father welcomed his lost son and was very happy with

${ }^{1}$ Hedlund, "Biblical Basis," 18.

${ }^{2}$ Donald McGavran, Understanding Church Growth (Madras: Evangelical Literature Service, 1970), 15.

${ }^{3}$ William Barclay, "Luke," The Daily Study Bible (Bangalore: Theological Publications in India, 1987), 4:201.

${ }^{4}$ Ibid.

${ }^{5}$ Ibid. 
his son's return. ${ }^{1}$ Jesus said, "There is joy in the presence of the angels of God over one sinner that repenteth" (Luke 15:10).

God is not concerned for mere searching, He wants His lost sheep to be found. In Matt 9:37 Jesus asked His disciples to pray that God would send laborers into the harvest field. He recognized the need for reapers, thus showing that mere proclamation is not enough. He wanted the grains to be collected and carried into His barns. ${ }^{2}$

Jesus emphasized the response to the gospel: "And whosoever shall not receive you, nor hear your words, when ye depart out of that house or city, shake off the dust of your feet" (Matt 10:14). He instructed the disciples not to waste time with those who rejected the gospel, but to hurry to those who would welcome it. Saul and Barnabas followed this instruction (Acts 13:51). Jesus was not interested in mere preaching but $\mathrm{He}$ was serious about a response. ${ }^{3}$

\section{God's Passion to Find}

God's passion for the lost is demonstrated in the parable of the great banquet in Luke 14:16-23. When the servants brought the news that the invited guests could not come, the master was not happy. He did not say, "Continue inviting those indifferent persons until they accept." "Instead he said, "Go quickly into the streets and lanes of the city and bring in hither the poor and the maimed and the halt and the blind" (Luke 14:21).

\footnotetext{
'Hedlund, "Biblical Basis," 18.

${ }^{2}$ McGavran, 40.

${ }^{3}$ Ibid.

${ }^{4}$ Ibid., 41 .
} 
When there was still room, he said to them again, "Go out into the highways and hedges, and compel them to come in, that my house may be filled" (vs. 23). As McGavran states, "Issuing the invitation was not the end; partaking of God's feast was. If one group would not accept the summons, the servant was to find other men who would."1

\section{The Gospel Commission}

Jesus, the founder of the church, chose the disciples and trained them by His exemplary life, by His teachings, and by His intimate association with them. His teaching by parables impressed their minds. He performed great miracles in the power of the Holy Spirit: He healed the sick (Matt 11:5), raised the dead (John 11:43), cast out demons (Matt 8:28-34), and stilled the storm (Luke 8:24). He manifested the character of God to others by His loving kindness and concern for others. He had twelve disciples in the beginning (Matt 10:1), and then the seventy (Luke 10:1), and gradually thousands followed Him. Jesus was crucified, but on the third day He rose. He appeared to the eleven disciples in Galilee (Matt 28:16, 17), then to a company of 500 believers (1 Cor 15:6). Before His ascension, He gave the gospel commission.

The very existence of the church is for evangelism, for the proclamation of the Word of God. It is the responsibility of each Christian to share the good news of salvation wherever he or she goes. As ambassadors of Christ, Christians should spread the message of Christ's death on the cross, His resurrection, and His promise to return. The gospel commission is recorded five times in Scriptures, once in each of the Gospels

${ }^{1}$ Ibid., 41-42. 
and once in the book of Acts (Matt 28:18-20; Mark 16:15; Luke 24:47-49; John 20:21; and Acts 1:8). Matthew's version reads:

And Jesus came and spake unto them, saying, all power is given unto me in heaven and in earth. Go ye therefore, and teach all nations, baptizing them in the name of the Father, and of the Son, and of the Holy Ghost; Teaching them to observe all things whatsoever I have commanded you; and, lo, I am with you always, even unto the end of the world. Amen.

Five principal elements appear in the gospel commission.

\section{Authority of Jesus}

Jesus has all authority on heaven and on earth. With the sovereign authority of God, He sends His disciples on a mission to evangelize the world. ${ }^{1}$ Hagner points out: "The universal authority of Jesus is the basis of the universal mission of the church." Already Jesus had given His disciples "power and authority over all devils, and to cure diseases" (Luke 9:1). Mark's mention of the gospel commission promises power over demons and sickness, as well as miracles and signs (Mark 16:17-18).

\section{Going into All the World}

The gospel commission is not restricted by national boundaries. This commission is often referred to as the "charter of foreign missions." Pagan religions were primarily national in character and did not always set out to make converts of other national groups. But Christianity is of an international character and believes in one great 1995), 886.

${ }^{1}$ Donald A. Hagner, Matthew, Word Biblical Commentary, vol. 33A (Dallas: Word,

${ }^{2}$ Ibid., 687.

${ }^{3}$ SDABC, $5: 557$. 
brotherhood ${ }^{1}$ in which "there is neither Jew nor Greek, there is neither bond nor free, there is neither male nor female; for ye are all one in Christ Jesus" (Gal 3:28). Going into all the world eliminates "all barriers of race, nationality, society, economics, and social custom.,"2

The gospel must be preached in all countries and cities. E. G. White wrote, "From town to town, city to city, from country to country, the warning message is to be proclaimed." ${ }^{3}$ Every church should have plans for its members to do this work. The gospel should be preached to all. When we go with this message, we will be endowed with divine energy. ${ }^{4}$ Countries once closed to the gospel are opening doors. God wants everyone to hear the last call for the marriage supper of the lamb. ${ }^{5}$

\section{Teaching}

It is just "as important to teach men to observe the things Christ has commanded as it is to baptize. In fact, faith in Christ calls for constant growth in the 'knowledge of our Lord and Saviour Jesus Christ' (2 Pet 3:18)." Instruction before and after baptism is of vital importance. The church is assigned to teach what Jesus has commanded to teach, because "any teaching that is without the authority of Christ has no place in the Christian

${ }^{1}$ Tbid.

${ }^{2}$ Ibid.

${ }^{3}$ E. G. White, Evangelism (Washington, D.C.: Review and Herald, 1946), 19.

${ }^{4}$ Ibid.

${ }^{5}$ Ibid., 22.

${ }^{6} \mathrm{SDABC}, 5: 557$. 
church."1

The church should edify or educate its people. According to Warren, "As the church, we are called not only to reach people, but also to teach them." ${ }^{2}$ Through teaching, spiritual maturity is developed in the church. The church exists "to edify, encourage, exalt, equip, and evangelize." Jesus asked the disciples to teach the people what He had taught them. We are not to teach tradition, human theory, or conclusions. We are to present the Word of God to the world. ${ }^{4}$

\section{Baptizing}

Jesus asked the disciples to baptize those who accepted His teachings (Mark $16: 15,16)$. The church must implement this commission because baptism is the result of the gospel commission. ${ }^{5}$ Baptism, as the "initiatory rite for converts, was to illustrate and make functional the motives Jesus had in being Himself baptized, and by immersion, to express the meaning of death to the old life and resurrection into the new life."

The church is commissioned to go, baptize, and teach because these are three essential elements in the disciple-making process. Baptism symbolizes fellowship and

'Ibid.

${ }^{2}$ Rick Warren, The Purpose Driven Church (Grand Rapids: Zondervan, 1995), 106.

${ }^{3}$ Ibid.

${ }^{4}$ Tbid.

${ }^{5} \underline{\mathrm{SDABC}}, 6: 21$.

${ }^{6}$ Tbid. 
identification with the body of Christ. ${ }^{1}$ By baptism we join God's family and become members of the body of Christ which is the church. Baptism "not only symbolizes our new life in Christ, it visualizes a person's incorporation into the body of Christ."2

\section{Continuing Presence of Jesus}

Jesus also promised His continuing fellowship to the disciples. He assured them that He would be with them always from that moment until the end of the world. The gospel commission is given to all Christians. They are to go forth as Christ's messengers to teach, instruct, and persuade men and women by the word of God. The presence of Christ will be with them (Matt 28:18-20).

\section{The Outpouring of the Holy Spirit}

Jesus asked His disciples to tarry in Jerusalem for the outpouring of the Holy Spirit (Luke 24:49; Acts 1:8). Without the Holy Spirit, they could not have done the great things performed on their missionary tours. The disciples gathered in the upper room as Jesus had commanded and prepared themselves to receive the Holy Spirit (Acts 2:1-4). On the day of Pentecost, "the Spirit of God was poured out and the church was inaugurated." Thus the church was "empowered to do for Christ what had never before been attempted, the preaching of the good news of salvation to all nations."4

\footnotetext{
${ }^{1}$ Warren, 105.

${ }^{2} \mathrm{Ibid}$.

${ }^{3} \mathrm{SDABC}, 6: 22$.

${ }^{4}$ Tbid., 137.
} 
A great demonstration of the power of the Holy Spirit was given. By the outpouring of the Holy Spirit, the "disciples were drawn together in a corporate selfconsciousness they had not before felt."' Three thousand people accepted Peter's invitation (Acts 2:41). "Many of those men had probably heard Jesus speak, some may have been healed by Him, others watched Him die." 2 This reveals that the seeds were sown earlier and resulted in the great harvest on the day of Pentecost. On that day many became followers of Jesus by the rite of baptism and joined the church. ${ }^{3}$

The Expansion of the Church

The book of Acts records in detail the expansion of the church. In this section a few passages on church growth found in the book of Acts are discussed.

\section{Acts 2:42-47}

And they continued steadfastly in the apostle's doctrine and fellowship, and in breaking of bread, and in prayers. And fear came upon every soul; and many wonders and signs were done by the apostles. And all that believed were together, and had all things common; and sold their possessions and goods, and parted them to all men, as every man had need. And they, continuing daily with one accord in the temple, and breaking bread from house to house, did eat their meat with gladness and singleness of heart, praising God, and having favor with all the people. And the Lord added to the church daily such as should be saved.

The new converts took part in four activities: (1) they listened to the teachings of the apostles, who were qualified to teach because of their special training and

${ }^{1}$ Ibid., 23.

${ }^{2}$ Balmer H. Kelly, ed., The Book of Acts, Layman's Bible Commentary (Richmond, Virginia: John Knox, 1960), 39.

${ }^{3}$ Ibid. 
companionship with Jesus; (2) there was fellowship and sharing of goods; (3) there were fellowship meals; and (4) they prayed. These were four essential elements in the religious practices of the early church. ${ }^{1}$

The wonders and signs which demonstrated the mighty power of Jesus were wrought by the apostles; these caused a sense of fear on the part of the people. The believers lived together and practiced a kind of social ownership of their possessions. Some people sold their possessions so that the proceeds might be used to help the needy. This was a society in which the members lived together and had everything in common. Each member of the church held his or her goods at the disposal of the others whenever the need arose. ${ }^{2}$

The early Christians were known for their religious devotion. "They met together in a spirit of unanimity in the temple" (Acts 2:46). They all took part in the daily worship in the temple. They met "in one another's houses and broke bread together in a spirit of intense and sincere joy" (Acts 2:46), meaning that they held communal meals. They were all inspired by those gatherings. They were thankful to God and praised Him. In fact, the church had continual evangelistic activity. ${ }^{3}$

\section{Acts $4: 4$}

Howbeit many of them which heard the word believed; and the number of the men was about five thousand.

'Ibid.

${ }^{2}$ Ibid., 84.

${ }^{3}$ Ibid., 86. 
The healing of the lame man (Acts 3:1-10) and Peter's sermon (Acts 2:14-40) made a great impression on the people, but these incidents also aroused the opposition of the Jewish leaders; Peter and John were arrested. They were given a warning by the authorities, but they could not stop preaching (Acts 4:18) because "the church cannot obey orders to give up its most characteristic activity, witness to the risen Lord, although it must be prepared to pay the price of its refusal to keep quiet."

The Jewish authorities arrived to arrest the apostles and the preaching came to an end. Though they were put in the prison (Acts 5:18-32), they could not stop the mighty work of the Holy Spirit in the hearts of the hearers. Many who heard the message of Peter responded, and 5,000 were added to the church.

\section{Acts 5:14}

And believers were the more added to the Lord, multitudes both of men and women.

The arrest of the apostles did not stop the growth of the church. "The preachers were persecuted, the word prevailed, for sometimes the church's suffering days have been her growing days, the days of her infancy were so."2 The mighty works of God demonstrated by the powerful healing ministry made a deep impression far and wide, even outside of Jerusalem. The number of converts increased day by day. ${ }^{3}$

\section{${ }^{1}$ Ibid., 97.}

${ }^{2}$ Matthew Henry, Matthew Henry's Commentary (Edinburgh: Marshall Morgan and Scott, 1960), 2:446.

${ }^{3}$ Howard Marshall, The Book of Acts, The Tyndale New Testament Commentaries, vol. 5 (Grand Rapids: Eerdmans, 1987), 144. 


\section{Acts 6:7}

And the word of God increased; and the number of the disciples multiplied in Jerusalem greatly, and a great company of the priests were obedient to the faith.

The Greek-speaking Christians criticized the arrangements for the care of the poor in the church. The apostles realized that their work load was too great. Seven men were appointed to take charge of the work, and hands were laid on them for this special task (Acts 6:3-6). This helped the church to grow because the gospel proclamation increased and was effective in winning converts. As a result the number of disciples continued to grow, and in particular there were converts among the priests (Acts 6:7).

\section{Acts $9: 31,35,42$}

Then had the churches rest throughout all Judea and Galilee and Samaria, and were edified; and walking in the fear of the Lord, and in the comfort of the Holy Ghost, were multiplied. ... And all that dwelt at Lydda and Sharon saw him, and turned to the Lord. ... And it was known throughout all Joppa, and many believed in the Lord.

By this time there were churches in Judea, Galilee, and Samaria (Acts 9:31). The number of converts multiplied by the ministry of the Holy Spirit. There was a conversion of a large group in Lydda and Sharon (vs. 35) as a result of the healing of Aeneas by Peter (vss. 33, 34). Peter raised Dorcas (vss. 36-41) by his prayer. This miracle was known throughout Joppa and many believed on the Lord (vs. 42).

\section{Acts 11:19-24}

Now they which were scattered abroad upon the persecution that arose about

${ }^{1}$ Ibid. 
Stephen travelled as far as Phenice, and Cyprus, and Antioch, preaching the word to none but unto the Jews only. And some of them were men of Cyprus and Cyrene, which, when they were come to Antioch, spake unto the Grecians, preaching the Lord Jesus. And the hand of the Lord was with them; and a great number believed, and turned unto the Lord. Then tidings of these things came unto the ears of the church which was in Jerusalem; and they sent forth Barnabas, that he should go as far as Antioch. Who, when he came, and has seen the grace of God, was glad, and exhorted them all, that with purpose of heart they would cleave unto the Lord. For he was a good man, and full of the Holy Ghost and of faith; and much people was added unto the Lord.

The persecution that arose over Stephen resulted in Philip's evangelistic labor,

Saul's conversion, Peter's missionary work, and the foundation of the church at Antioch. The refugees from Jerusalem came to Antioch and preached Jesus to the Jews who lived there. Some of the refugees even preached to the Gentiles, and they accepted the gospel in great numbers. The Jerusalem church sent Barnabas, a good man, full of the Holy Spirit and full of faith, to Antioch. The church grew under the ministry of Barnabas.

\section{Acts 16:5}

And so were the churches established in the faith, and increased in numbers daily.

Paul returned to Derbe and Lystra to visit the churches. The purpose of the missionary's visit was to establish the churches by strengthening its members. This was Paul's strategy. As a result of the Gentile conversion, the number of Christians multiplied daily. There was an increase in the number of congregations also.

\section{Church Growth in the Literature}

\section{General Principles}

This section deals with Schwarz's eight essential qualities of healthy churches and Zachariah's seven growth principles for India. 


\section{Schwarz's Eight Essential Qualities of}

\section{Healthy Churches}

Schwarz presents the practical conclusions drawn from the most comprehensive study ever conducted on the causes of church growth in more than 1,000 churches in thirty-two countries. He notes eight essential qualities of healthy churches that lead to growth:

1. Empowering leadership. The Christian leader should find out the potential of the members of his church, and should equip, motivate, and empower its members. ${ }^{2}$

2. Gift-oriented ministry. For a successful ministry the church leadership should help the laity to identify their spiritual gifts and integrate them into appropriate ministry. ${ }^{3}$

3. Passionate spirituality. There should be prayer and commitment of the Christians and the whole congregation should be on fire. ${ }^{4}$

4. Functional structures. There must be development and continuous evaluation of church structures which promote an ongoing multiplication of the ministry. ${ }^{5}$

5. Inspiring worship service. Growing churches have worship services that inspire people. Evaluate the worship services regularly. ${ }^{6}$

${ }^{1}$ Christian A. Schwarz, Natural Church Development (Carol Stream, Illinois: Church Smart Resources, 1996), 3.

${ }^{2}$ Ibid., 22, 23.

${ }^{3}$ Ibid., 24.

${ }^{4}$ Ibid., 26.

${ }^{5}$ Ibid., 28.

${ }^{6}$ Ibid., 30. 
6. Holistic small groups. Growing churches have continuous multiplication of small groups through cell division. ${ }^{1}$

7. Need-oriented evangelism. Every congregation should "focus its evangelistic efforts on the questions and needs of non-Christians."

8. Loving relationships. The members of the church do not want to hear about love, but they want to experience it. Love and hospitality should be practiced by all Christians. $^{3}$

These factors must be present to release the growth potential within the church

\section{Zachariah's Seven Growth Principles}

Zachariah presents seven growth principles for India. He says that for a church to grow, its leaders must:

1. Preach, persuade, and plant. The church has to fulfill the gospel commission by preaching, persuading, and planting new churches. ${ }^{4}$

2. Concentrate on the responsive people. The gospel must be preached to all, but the common people are the most receptive. It should be preached both in cities and villages and among all the castes of India. ${ }^{5}$

3. Be ready for a power encounter. When Jesus was on this earth, by seeing His

${ }^{1}$ Ibid., 32-33.

${ }^{2}$ Tbid., 34-35.

${ }^{3}$ Ibid., 36.

${ }^{4}$ C. Zachariah, "Seven Growth Principles for India," India Church Growth 1 (1984): 98.

${ }^{5}$ Tbid. 
miracles and healing, multitudes came to Him. Jesus has given the same authority to all Christians, and in a country like India, the power encounter is very effective. ${ }^{1}$

4. Mobilize the laity. The lay members want to do the work of the Lord, but quite often they are not mobilized properly. It is high time to recognize the talents and spiritual gifts of the laity and encourage them for the ministry. ${ }^{2}$

5. Multiply house churches. In New Testament times, the house churches played an effective role in church growth. People hesitate to come to large churches, but they are comfortable in house churches. ${ }^{3}$

6. Plant people churches. There are many people groups in the society. When a particular group joins the church, their social structure should be allowed to continue. Establishing churches without disturbing the social continuity is possible. ${ }^{4}$

7. Encourage people movements. The New Testament church grew by people movements. In Samaria, multitudes believed in Jesus (John 4:41). As people consciousness is strong in India, people movement is the best means for evangelism. ${ }^{5}$

\section{Specific Principles for Kottayam}

This section emphasizes church growth principles that the researcher considers most significant and appropriate for the Indian setting, especially for Kottayam. These

${ }^{1}$ Ibid.

${ }^{2} \mathrm{Ibid}$.

${ }^{3}$ Ibid.

${ }^{4}$ Ibid.

${ }^{5}$ Ibid. 
are: effective pastoral care, prayer ministry, inspiring worship services, small-group ministry, revival meetings, and lay training.

\section{Effective Pastoral Care}

Pastoral care is defined as "helping acts done by representative Christians directed towards the healing, sustaining, guiding, and reconciling of troubled people."1 As a shepherd, the pastor knows the names of the sheep and knows their needs and should protect them. He must feel their needs and share in their fortunes for good and ill. ${ }^{2}$ For effective pastoral care, the pattern of Jesus should be followed. Taylor observes the following points about His ministry: (1) Jesus had a deep conviction that people should live the best and fullest sort of life; (2) Jesus felt a deep compassion for all people, especially those who were "harassed and helpless" (Matt 9:35, 36); (3) Jesus' compassion was blended with authority; (4) Jesus accepted people as they were; (5) Jesus was impartial, he did not favor any particular person or group; (6) Jesus made Himself available to people in need; (7) Jesus gave great importance to helping and counseling individuals; (8) Jesus used different methods in helping different sorts of people; (9) Jesus was quick to offer encouragement and praise; and (10) Jesus saw a very close connection between the healing of the body and the healing of the soul. ${ }^{3}$

Specific elements in the pastoral care are counseling, visitation, and nurturing.

${ }^{1}$ Harold Taylor, Tend My Sheep (Southampton: SPCK, 1983), 30.

${ }^{2}$ William K. Anderson, The Minister and Human Relations (Nashville: General Conference Commission of the Methodist Church, 1943), 42.

${ }^{3}$ Taylor, 13-16. 
Counseling

The pastor should be a good counselor. Great care should be exercised in counseling, practicing the qualities of godliness, patience, and sensitivity. The pastor must avoid being shocked by frank disclosures. In sexual, family, or marriage problems, personal judgments should not be voiced before the complete picture of the problem is understood. The person must be pointed to Christ, who can help with all problems. Then the person can be sent away with prayer. ${ }^{1}$

Visitation

Home visitation is the basis of pastoral care. The purpose of visiting is to get to know the people and to have fellowship with them. The pastor should conclude the visit with prayer and a word of encouragement. An expression of sympathetic understanding will uplift the laity. ${ }^{2}$

As doctors, lawyers, and other professionals keep careful records, the pastor should keep records of visitation. Emphasis should be placed on visiting inactive members. Larom advises: "Visit the sheep, but don't neglect the goats." should organize visiting teams to assist in visitation.

Visiting on special occasions. When the pastor is invited for a baptism, an anniversary, a birthday, or any special occasion, it is imperative to keep the appointment.

'Peter Larom, Pastor: A Practical Guide for Church Leaders (Achimota, Ghana: West Africa Christian Press, 1989), 98-99.

${ }^{2}$ Ibid., 92.

${ }^{3}$ Ibid., 93. 
This provides a good opportunity to meet members and friends of the family who may not be church members. On these occasions, the pastor should offer an appropriate prayer. ${ }^{1}$

Visiting the sick. The sick should be visited immediately. The pastor should comfort them, encourage them, and pray for healing. Sometimes the pastor will be asked to anoint the sick person with oil. The church elders can be invited to this service. The sick should be encouraged to look to Jesus, not the oil. When prayer is offered for the sick, the pastor should touch them, because "the laying of hands for healing is meant to physically and spiritually nurture the sick, and the firm hand of the pastor will give great comfort to the weak."

Visiting the dying. Ministry to the dying is important. Dying persons may wish to unburden their sins or some anguish which they cannot tell to anyone else. Sometimes they may have some last wishes which they want to impart to a trustworthy person. So a pastor must not avoid visiting a dying person. Sometimes, when it is impossible to say anything to the dying person, the presence of the pastor at the bedside will comfort the family. ${ }^{3}$

\footnotetext{
${ }^{1}$ Ibid., 93.

${ }^{2}$ Ibid., 94.

${ }^{3}$ Ibid., 94-95.
} 
Nurturing

Nurturing is an on-going process. All the programs of the church should be for the nurturing of its members. There should be a nurturing of the spiritual life with the Word of God, because it gives hope and comfort to the believers, and it strengthens them in times of trials. When there is negligence in nurture, the people become nominal. ${ }^{1}$

Nurturing members to maturity and productivity requires "time, consistency, fellowship with God through regular Bible study and prayer, worship, and fellowship."2 There should be a personal touch and intimacy as the new members walk together with God. New members need to understand that the study of the Word of God is necessary for spiritual growth. ${ }^{3}$

There should be a parental attitude in the nurturing process. The personal touch is significant. Paul wrote, "But we were gentle among you, even as a nurse cherisheth her children" (1 Thess 2:7), and "we were willing to have imparted unto you, not the gospel of God only, but also our own souls, because ye were dear unto us" (vs. 8). He further wrote: "We exhorted and comforted and charged everyone of you, as a father doth his children" (vs. 11). There should be the nursing and cherishing of the mother and the sharing, encouragement, and exhortation of the father. ${ }^{4}$

${ }^{1}$ Roger E. Hedlund, God and the Nations: Biblical Theology of Mission in the Asian Context (Delhi: Indian Society for Promoting Christian Knowledge, 1997), 94.

${ }^{2}$ Billy Graham Evangelistic Association, "Discipleship and Follow-up," India Church Growth 2 (1989): 7, 8.

${ }^{3}$ Ibid., 8.

${ }^{4} \mathrm{Ibid}$. 


\section{Prayer Ministry}

Jesus is the model for all Christians, because He has set an example for us to follow in His footsteps (1 Pet 2:21). His life was a life of prayer, "and in the morning rising up a great while before day, He went out and departed into a solitary place, and there prayed" (Mark 1:35). This passage shows that it was the custom of Jesus to pray in the early morning every day. Not only in the mornings, but also in the evenings $\mathrm{He}$ prayed: "And when He had sent them away, he departed into a mountain to pray" (Mark 6:46). Moreover, He commanded His followers to pray always (Luke 18:1), because God hears the prayers of His children (Ps 65:2).

Through prayer a loving contact with God is maintained. Prayer gives strength to cope with the trials and tribulations of life. We get forgiveness through prayer. Through prayer "we turn sorrow into joy and defeat into victory. Through prayer we lay hold of a power greater than our own; a power equal to every need." Zachariah observes:

"Christ's earthly life and His teachings place a very great emphasis on prayer. The early church was born in the atmosphere of prayer. She received her vitality through prayer."2

\section{Importance of prayer}

According to Robb there are nine compelling reasons to pray. ${ }^{3}$ They are:

1. God desires and requires intercessory prayer for the accomplishing of His

${ }^{1}$ Wilber La Roe, The Church We Love (New York: Abingdon, 1958), 57.

${ }^{2} \mathrm{C}$. Zachariah, "The Present Growth of the Assemblies of God Congregations in Tamil Nadu," India Church Growth 1 (1984): 279.

${ }^{3}$ John D. Robb, Focus! The Power of People Group Thinking (Madhupur: Mission Educational Books, 1994), 103. 
saving purpose for the peoples of the earth. ${ }^{1}$

2. Victory in the spiritual realm is primary, and it is won by prayer. ${ }^{2}$

3. Prayer has always undergirded and extended the missionary outreach of the church. ${ }^{3}$

4. Spiritual survival wrought by prayer has a major impact on frontier missions. ${ }^{4}$

5. Intercessory prayer enables God's children to possess their inheritance, the peoples of the earth. ${ }^{5}$

6. Effective mission strategies come from research permeated with prayer. ${ }^{6}$

7. Prayer is the supernatural way of multiplying and sending out Christian workers into frontier missions. ${ }^{7}$

8. Prayer opens closed doors for the entry of the Christian message. ${ }^{8}$

9. Aggressive praying or spiritual-warfare praying breaks the control of the powers of darkness over people groups, cities, and nations. ${ }^{9}$

${ }^{1} \mathrm{Ibid}$.

${ }^{2}$ Ibid., 106.

${ }^{3}$ Ibid., 107.

${ }^{4}$ Robb, 111 .

${ }^{5}$ Ibid., 114.

${ }^{6}$ Ibid., 116.

'Tbid., 117.

${ }^{8}$ Ibid., 118.

${ }^{9}$ Ibid., 120. 
Prayer and church growth

The secret behind the growth of the church in Seoul, Korea, was fervent prayer. When Paul Yonggi Cho started his career as a pastor, his congregation consisted of only five people. Every night he prayed until the early hours of the morning for the congregation to increase. As a result of his prayer, signs and wonders took place, many broken hearts were healed, and people felt the moving of the Holy Spirit in their lives. Prayer helped them to have a close walk with God. God wants to have a loving communion with His people through prayer. ${ }^{1}$

A revival in South Korea started when 400 pastors gathered in 1958 to pray for a week. The secret of Korean church growth is "early morning prayer, weekly all-night prayer, continuous prayer in the 'prayer mountains,' 'praying spirit-filled pastors', and involvement of the youth and the women in prayer."2

The distinctive mark of the Chilung Church of the Taiwanese-speaking people of Taiwan was the deep and persistent emphasis on prayer. On holidays about forty believers gathered from six to nine in the morning in small groups for prayer from 1954 through 1969. On Wednesday evenings they spent forty-five minutes on their knees. This was the secret behind the growth of this church. ${ }^{3}$

The church of South India (CSI) Redeemer's Church at Madras grew from 1979

'Paul Yonggi Cho, "The Secret Behind the World's Biggest Church," India Church Growth 2 (1989): 130.

2“Korea: The First International Prayer Assembly," India Church Growth 2 (1989): 57.

${ }^{3}$ Allen J. Swanson, ed., I Will Build My Church: Ten Case Studies of Church Growth in Taiwan (Taichung: Taiwan Church Growth Society, 1977), 81. 
because a prayer box was kept outside the church so that the passersby could drop their prayer requests in it. Every Friday the prayer group of the church emptied the box and prayed for their requests. When the prayers were answered, many people, including Hindus, gave thank offerings to the church. ${ }^{1}$

Logan provides the following action steps for prayer. Choose an appropriate place to concentrate attention upon God. Have a prayer list and a journal to record impressions. Having a prayer partner multiplies exponentially the power of prayer. Reserve a specific time for prayer and make it the most productive of the day. In addition, recruit an intercessory team for prayer. $^{2}$

\section{Inspiring Worship Services}

God is the Creator, Redeemer, and Sustainer of all human beings. He is the ultimate authority, and all human beings should worship Him. The Bible says whom to worship, how to worship, when, and why to worship. The fourth commandment says whom to worship and when to worship (Exod 20:8-11). John clearly admonishes to worship the creator God: "Worship Him that made heaven and earth and the sea and the fountains of waters" (Rev 14:7). The psalmist says how to worship Him: "O worship the Lord in the beauty of holiness; fear before him, all the earth" (Ps 96:9). Again he urges people to worship God for all His benefits or blessings (Ps 103:2), for His goodness and (1984): 204.

'M. D. Selvaraj, “A C.S.I. Church in Madras Is Growing,” India Church Growth 1 36.

${ }^{2}$ Robert Logan, Beyond Church Growth (Grand Rapids: Fleming H. Revell, 1989), 35, 
wonderful works (Ps 107:21), and for all His mighty acts (Ps 150:2).

Worship has been defined as "an active response to the person and work of God." Its goal is "to inspire unchurched people in a way that they would feel that they have met with God." In the conversation with the Samaritan woman Jesus said, "God is a spirit; and they that worship Him must worship in spirit and in truth" (John 4:24). In vital worship, communication "between God and believers, between believers and their fellow believers, between believers and the unchurched"2 is indispensable.

Worship is a celebration of the holiness of God. When the believers come together for worship in a separate place, at an appointed time, they acclaim God's holiness. ${ }^{3}$ Worship is the human response to the living God; and it is "acknowledging the worth-ship of God." Through the worship service "God continues His redemptive activity whereby the believers are nourished and inspired." Worship services should be God centered; the thought and intense desire of the worshipper should be fixed on God. The worship services should exalt God. Effective worship will transform the worshipers. ${ }^{6}$

Logan enumerates the benefits of effective worship: It is meaningful to regular

${ }^{1}$ Ibid., 76.

${ }^{2}$ Tbid., 83 .

${ }^{3}$ Larom, 71 .

${ }^{4}$ James D. Robertson, Minister's Worship Handbook (Grand Rapids: Baker, 1974), 13.

${ }^{5}$ Ibid., 18.

${ }^{6}$ Thomas Bruce McDormand, The Art of Building Worship Services (Nashville: Broadman, 1958), 3-4. 
attenders; it is comprehensible to newcomers; it is alive to the presence of God; and it is response oriented. ${ }^{1} \mathrm{He}$ further points out that worship services should be progressive, God oriented, purposeful, and enthusiastic. They should encourage participation, be relational, and smooth flowing. Good worship is celebrative yet reflective, easy to listen to, and comfortable. In addition it is Bible based, and encourages closeness to God. ${ }^{2}$

\section{People Group Approach}

Robb defines a people group as follows:

A significantly large grouping of individuals, who perceive themselves to have a common affinity for one another, because of their shared language, religion, ethnicity, residence, occupation, class or caste, situation, or combination of these. It is the largest group within which the gospel can flow along natural lines without encountering barriers of understanding or acceptance due to culture, language, geography, etc. ${ }^{3}$

McGavran provides the classical definition of a people movement as follows:

A people movement results from the joint decision of a number of individuals-whether five or five hundred--all from the same people, which enables them to become Christians without social dislocation, while remaining in full contact with their non-Christian relatives, thus enabling other groups of that people, across the years, after suitable instruction, to come to similar decisions and form Christian churches made up exclusively of members of that people. ${ }^{4}$

When the members of a certain social group move into the Christian faith, a people movement to Christ occurs. The people movement approach to evangelism is biblical. The story of the children of Israel in the Old Testament is the story of a people

\footnotetext{
${ }^{1} \operatorname{Logan}, 90$.

${ }^{2}$ Tbid., 93.

${ }^{3}$ Robb, 8.

${ }^{4}$ McGavran, 297-298.
} 
movement. The conversions of Cornelius's household (Acts 10:47, 48), Lydia and her household (Acts 16:15), and the Philippian jailor's household (Acts 16:33) are a few of the examples of people movements in the New Testament.

Hedlund mentions the two major patterns of conversion: one-by-one conversion pattern, and multi-individual (group) conversion or people movements. In India, where the caste system prevails, people movements have taken place in several areas. ${ }^{1}$

It is estimated that 80 percent of the Christian community in India is the result of people movement conversion. People movements from caste and people movements from tribes have been the two major types of people movements in India. The fisher castes of South India, the Nadars of Tirunalvelly and Kanyakumari, the Vellalas of Tamil Nadu, the Malas and Madigas of Andhra Pradesh, and the Wamshudras of Bangladesh are a few examples of people movements in Southern Asia. ${ }^{2}$

The term "people" means "the members of a particular social group such as a tribe, caste, class, clan, or lineage."3 People movements do not result in nominal Christianity if there is real care, feeding, and proper nurturing. Conversion is only a beginning, but after-care makes the difference. ${ }^{4}$ Special care is needed for the newly converted people groups. As McGavran states, “A well-shepherded people movement 64.

${ }^{1}$ Roger E. Hedlund, Building the Church (Madras: Evangelical Literature Service, 1982),

${ }^{2}$ Roger E. Hedlund, "People Movements," India Church Growth 1 (1984): 66.

${ }^{3}$ Ibid., 65.

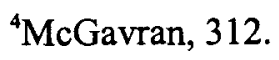


has a soundly Christian character." The people are highly teachable during the first few months after conversion because during this time they eagerly learn the Christian way. They must be taught the habits of attending, learning, worshiping, and giving in this period. ${ }^{2}$

There are some advantages to the people group approach: (1) It ensures that ministry to a particular target group will be holistic; (2) it breaks down the world into manageable segments; (3) it makes the ministry of the church measurable; (4) it is the strategic way; it helps to minister in-depth to a target group and focus the attention of the church on its unfinished task; and (5) it encourages people movements to Christ. ${ }^{3}$

People movements from tribes have taken place in Northeast India where people consciousness is high. The people have converted from animism; but the people movements have helped to preserve tribal unity and identity. Many groups have come to Christ tribe-by-tribe, family-by-family, sub-group by sub-group. ${ }^{4}$

\section{Lay Training}

Training is a vital part of the experience of all workers for God. Jesus spent three and a half years with His disciples training them. Timothy was trained by Paul (Acts $16: 1-4 ; 1$ Thess $3: 1,2$ ). The primary emphasis in training is to develop Christian character in the trainees, such as integrity, faithfulness, stewardship, prayer, humility, and

'Ibid., 313.

${ }^{2}$ Ibid., 314 .

${ }^{3}$ Robb, 24-26.

${ }^{4}$ Ibid., 66-67. 
love.

If a church is to grow, it must equip its members for evangelism, to lead others to Christ. If regular training is provided, the lay members will be able to develop their spiritual gifts. The training should enhance the vision and mission of the church. Training can be a vehicle to create bridges to the community. ${ }^{1}$

Ron Jenson and Jim Stevens define training as follows:

Training is an activity which by its nature involves repetition. In I Timothy 4:7 (NASB), Paul tells Timothy, "Discipline yourself for the purpose of godliness." The word discipline is used of an athlete practicing gymnastic exercises. Training involves practice. Practice involves repeating an exercise or technique until the skills developed become second nature and a way of life. ${ }^{2}$

The primary task of the pastor is to train or equip the laity for ministry. The pastor should spend time in helping the laity to discuss their spiritual gifts and put them in ministry. Training is an absolutely vital component for effective ministry. In reality, the local church is a mini-seminary and the pastor, the dean. The principal responsibility of the church is to be a training center for Christian workers. ${ }^{3}$

Wagner defines an equipper as the leader who "actively sets goals for a congregation according to the will of God, obtains goal ownership from the people, and sees that each member is properly motivated and equipped to do his or her part in accomplishing the goals." The pastor who spends most of the time training and

${ }^{1}$ Russell Burrill, Revolution in the Church (Fallbrook: Hart Research Center, 1993), 109.

${ }^{2}$ Ron Jenson and Jim Stevens, Dynamics of Church Growth (Grand Rapids: Baker, 1981), 167.

${ }^{3}$ Burrill, 50, 52.

${ }^{4} \mathrm{C}$. Peter Wagner, Leading Your Church to Growth (Ventura: Regal, 1984), 79. 
equipping the laity will have a spiritually strong church. Training is the best nurture which can be given to the church. ${ }^{1}$

According to Neill's observation, "A church cannot become genuinely independent unless it has local leaders capable of replacing the missionary in every level of thought and activity."2 Abbiss states, "The training program should meet the needs of the church. Men and women should be trained to develop the local church, personal witnessing, cottage meetings and open-air meetings." ${ }^{, 3}$ Russell Burrill emphasizes that the church should discover the spiritual gifts of the laity, and set up an on-going training program for various church ministries. ${ }^{4}$

One of the important principles of church growth is training lay members. Lay members should do evangelism, because they are the most strategic people. ${ }^{5}$ The apostle Paul trained lay people for preaching the gospel. According to E. G. White, "the apostle made it a part of his work to educate young men for the office of the ministry. He took them with him on his missionary tours and thus they gained an experience that later enabled them to fill positions of responsibility."

As soon as a congregation decides to start a local lay ministry training center, it should make a curriculum. The courses should include diverse matters such as ushering,

${ }^{1}$ Burrill, 107, 108.

${ }^{2}$ Stephen Neill, A History of Christian Missions (New York: Penguin, 1979), 517.

${ }^{3}$ G. G. Abbiss, "Training at Hebron," India Church Growth 2 (1989): 11.

${ }^{4}$ Burrill, 34.

${ }^{5}$ Marlin L. Nelson, Principles of Church Growth (Bangalore: Acts Trust, 1995), 78.

${ }^{6}$ E. G. White, The Acts of the Apostles (Mountain View: Pacific Press, 1911), 368. 
teaching a Sabbath School class, and carrying out the duties of elders and other church leaders. Classes in biblical studies will enhance the Bible knowledge of the members. Specific courses on witnessing and evangelism should also be taught. ${ }^{1}$

When a conference-wide training program is arranged, only a few members from local churches attend. If there is a training program in the local church, every member will be able to attend. Every Seventh-day Adventist local church should be a training center. Small churches can combine and have a district-wide training program. Through lay ministry training centers, the laity can be effectively trained. ${ }^{2}$

A missionary society named the Association of Baptists for World Evangelism, with headquarters in Philippines, started work in the Philippines in 1927, and by 1962 they had raised 215 churches with 12,000 members. This was done by theology students. Students were assigned to a town to begin a Sunday school. They then conducted six to twelve weeks of intensive evangelistic campaign. ${ }^{3}$

Lay training programs

The Mar Thoma Church has founded a lay institute at Tiruvalla. It gives shortterm training of about three months. Some of the trained men have become evangelists and some have enlisted for further seminary training. It is managed by the Voluntary Evangelists Association. ${ }^{4}$

${ }^{1}$ Burrill, 111-112.

${ }^{2}$ Ibid., 107.

${ }^{3}$ McGavran, 364-365.

${ }^{4}$ Roger E. Hedlund, "Contextualized Protestant Missionary Training," India Church Growth 1 (1984): 165, 166. 
S. D. Ponraj's grassroots Church Planters Training Program helps to train thousands of grassroots evangelists and church planters to reach the unreached people groups of North India. It is an attempt to identify and train at least 50,000 local church planters who will be able to work among the 250,000 villages of North India. The training lasts three to six months. ${ }^{1}$

In Latin America, extension education for church multiplication was successful at the Honduras Bible Training Institute. The program was called "obedience-oriented pastoral course." There was multiplication of churches through the extension chains. This strategy can be adapted to the Indian situation.

Stephen Chen, who directs Theological Education by Extension at China Evangelical Seminary in Taipei, said: "The church in Taiwan will grow 50 percent during the next 10 years if they train the needed leaders. Taiwan now has 2,000 Protestant churches."3 Regarding the great need of the church he observes that "each church needs at least 10 trained lay leaders; it means 30,000 trained laymen are needed for 3,000 churches. The Theological Education by Extension program offers training on discipleship and theological education for lay leaders."

'S. D. Ponraj, The Grass Root Church Planter's Training Handbook (Madhupur: Mission Educational Books, 1996), 7, 16.

${ }^{2}$ Kumar Dass, "Extension Education for Church Multiplication," India Church Growth 1 (1984): 176.

3"News From Abroad," India Church Growth 1 (1984): 237.

${ }^{4}$ Ibid. 
Lay participation in outreach

The church is the people of God, called by Jesus Christ, and nourished by the Word of God to be a bridge between God and the world. The church is the messenger of God proclaiming the good news of God's wonderful deeds. ${ }^{1}$ The entire laity is to be mobilized to disciple the nation through active evangelism and church planting ministries. Lay members can witness for Christ "in their places of work, in hospitals, colleges, offices, villages, schools, and factories. Lay people's time, energy, and money should be channeled to evangelize non-Christians."2

According to George Peters, "Mobilization is an effort to mobilize every Christian believer--man, woman, child, illiterate, intellectual, new Christian, and mature disciple in an all-out witness to Jesus Christ." ${ }^{33}$ Gerber notes, "Churches are people. Responsible, reproducing churches are communities of people who are committed to Christ and to His command to establish other communities of Christian people."^4

In the postapostolic age, the lay people participated wholeheartedly in outreach activities. The traders, the soldiers, the slaves, and all Christians shared the Christian

'Sunand Sumitra and F. Hrang Hkuma, eds., Doing Mission in Context (Bangalore: Theological Book Trust, 1995), 33-34. Nadu," 279.

${ }^{2}$ Zachariah, "The Present Growth of the Assemblies of God Congregations in Tamil 218.

${ }^{3}$ George W. Peters, A Theology of Church Growth (Grand Rapids: Zondervan, 1982),

${ }^{4}$ Vergil Gerber, God's Way to Keep a Church Going and Growing (South Pasadena: William Carey, 1973), 18. 
faith with others. ${ }^{1}$ Harnack states, "We cannot hesitate to believe that the great mission of Christianity was in reality accomplished by means of informal missionaries."2

Every member of the church is a missionary. The task of the church is to persuade men and women to become Christians in order that they might make other Christians. All Christians are witnesses to their faith and that faith should accompany them wherever they go. ${ }^{3}$

The Bible pattern

The most vital and fruitful periods of the Christian church were when lay people most earnestly propagated the good news of Jesus Christ. Every member of the early church spread the Christian religion more than any of their successors did. ${ }^{4}$ When there was a persecution in the early church, the Christians were scattered and they "went everywhere preaching the word" (Acts 8:1,4). Every Christian was a witness of the gospel.

The ultimate evangelistic goal of the New Testament church was to make responsible, reproducing Christians and to make responsible, reproducing congregations. ${ }^{5}$ The number one priority of the early church was evangelism. In the early church, every 2.

${ }^{1}$ John R. Mott, Liberating the Lay Forces of Christianity (New York: Macmillan, 1932),

${ }^{2}$ Adolf Harnack, The Expansion of Christianity in the First Three Centuries (New York: Putnam's Sons, 1904), 1:460.

${ }^{3}$ A. R. Tippett, ed., God, Man and Church Growth (Grand Rapids: Eerdmans, 1973), 59.

${ }^{4}$ Mott, 1.

${ }^{5}$ Gerber, 18. 
member was a witness of Christ. Christianity spread rapidly in the first three centuries because every member was mobilized and actively involved in witnessing work.'

Results of lay participation

The Redeemer's Church at Madras (CSI) was born through a house church and grew because of the enthusiastic involvement of the lay members. In 1958 a stewardship conference for lay members was conducted and they were mobilized to plant new house churches. From the beginning this church was edified by the unceasing labor of lay members. ${ }^{2}$

A survey has been made among fifty-eight congregations of the Assemblies of God in Tamil Nadu. It was found that the congregation in which more lay members were involved in the ministry won more converts than the other churches where the pastor alone ministered. ${ }^{3}$

The secret of the growth of the largest Protestant church in the world at Seoul, South Korea, is evangelism. The believers are zealous in telling others about Jesus and bringing others to church. Even the women take part in active evangelism. The lay members do much witnessing and invite friends and relatives to attend church with them. They conduct street meetings where a group of Christians gather to sing, pray, preach,

${ }^{1}$ Michael Green, Evangelism Through the Local Church (London: Hodder and Stoughton, 1991), 410.

${ }^{2}$ Selvaraj, 204.

${ }^{3}$ Zachariah, "The Present Growth of the Assemblies of God Congregations in Tamil Nadu," 278. 
and to distribute tracts. ${ }^{1}$

\section{$\underline{\text { Small-Group Ministry }}$}

Within a church, a small group is "an intentional gathering of three to twelve people who commit themselves to work together to become better disciples of Jesus Christ." 2 These groups can function as prayer circles, Bible study groups, fellowships, sharing and caring groups, evangelistic teams, house churches, and covenant groups. The purpose of small groups is to equip effective leaders who can make disciples through the groups. The small-group ministry helps to discover the spiritual gifts of the members and equip them to use their gifts. It also helps to have effective congregational care by planning outreaches, visiting the sick, comforting the bereaved, and ushering services. ${ }^{3}$

The sign of a growing church is the cell group. A few members of a congregation meet together in a home to study the Bible, to share their Christian experience, and pray for one another. They are motivated to use their spiritual gifts for God's service. ${ }^{4}$ E. G. White said, "If there is a large number in the church, let the members be formed into small companies, to work not only for the church members but for unbelievers also." Bahadur says: "Every Christian is an evangelist, every Christian home a house-church,

'Nelson, 12-15.

${ }^{2}$ Jeffrey Arnold, The Big Book on Small Groups (Downers Grove: InterVarsity, 1992), 9.

${ }^{3}$ Ibid.

${ }^{4}$ Roger L. Dudley and Des Cummings, Jr., Adventures in Church Growth (Hagerstown: Review and Herald, 1983), 34.

${ }^{5}$ White, Evangelism, 115. 
every local church a training ground and every pastor a trainer."1

According to Reid, small groups are used for educational purposes, to organize into mission groups, for therapeutic purposes, to focus on personal growth, to improve communication, to enrich seasonal worship programs, and for Bible study and prayer. ${ }^{2}$ Jesus spent three years in a small group of twelve men. Chaney and Lewis note: "Just as an extension cord can become a conductor of electrical power as the electrical current flows through its various wires, small groups become conductors of life power as the lifecurrent of Jesus Christ flows through its various members."3 Small-group dynamics can be utilized for church growth. In all groups, communication on many levels is possible, spiritual growth is achieved, behavior changes, and leadership is formed. ${ }^{4}$ Philip states: "Through small groups/house churches the local church should build its own mission and evangelistic base."5

How cell groups function

Cell groups go through four stages: (1) the get-acquainted stage; (2) the conflict stage; (3) the community stage; and (4) the ministering-to-others stage. ${ }^{6}$ Cell groups

'Raja Bahadur, "Prayer Evangelism,” India Church Growth 2 (1989): 9.

${ }^{2}$ Clyde Reid, Groups Alive--Church Alive: The Effective Use of Small Groups in the Local Church (New York: Harper and Row, 1969), 17-27. 1977), 177.

${ }^{3}$ Charles Chaney and Ron Lewis, Design for Church Growth (Nashville: Broadman,

${ }^{4}$ Ibid., 152.

5Abraham Philip, “House Churches," India Church Growth 1 (1984): 194-195.

${ }^{6}$ Ralph W. Neighbour, Jr., The Shepherd's Guidebook (Houston: Touch, 1996), 148-149. 
usually have a six-month life, after which they are expected to multiply and start daughter cell groups. By this time cell group leaders will be trained.

There are "House churches, cells, Discipleship groups, Growth groups, Neighborhood Bible studies, Shepherd groups, Prayer cells, Lay evangelistic group studies, Home Bible studies, Men's fellowships, Women's fellowships, and so on." These small groups are formed for a variety of purposes such as, "nurture, outreach, church planting, event follow-up prayer, growth, accountability, praise and worship, fellowship, etc."2

The functions of the small groups are to "comfort one another and to edify one another" (1 Thess. 5:11). They also help to consider one another and to exhort one another (Heb. 10:24-25), to confess faults to one another and to pray one for another (Jas 5:16). Moreover, the small groups provide opportunity to care one for another (1 Cor $12: 25)$, and to serve one another (Gal 5:13).

In the beginning the members of the small group may not be able to pray well, but they can talk to God and thank God for answered prayers; they can pray for the needs of the week. Everything a small group does together helps prepare its members for service and involve its members in service. ${ }^{3}$ A small groups provide an intimate atmosphere in which one can flourish in interpersonal relationships. It shares the burdens of other members. It is a place where laughter and tears may be shared. ${ }^{4}$

Arn said, "Small groups are the purifying element of the church. They are the (1996): 6 .

'Bob Waymire, "Small Group Studies and Church Planting," India Church Growth 3

${ }^{2}$ Ibid.

${ }^{3}$ Bob Couchman and Win Couchman, Small Groups: Timber to Build up God's House (Wheaton, Illinois: Harold Shaw, 1992), 59.

${ }^{4}$ Lyman Coleman, Small Group Training Manual (Littleton: Serendipity, 1991), 17-18. 
praising element of the church. They are dynamic. The church needs small groups as the loaf needs yeast." Regarding the New Testament church, McGavran remarked, "The church was not of 5000 or 2000 members. They assembled in houses, 15-30 people. Everybody knew everybody else. They cared for each other."2

In China and the former Soviet Union, thousands became Christians through the ministry of the small groups. In the Philippines in the 1970s and 1980s small-group Bible studies met and thousands of new churches were established. ${ }^{3}$ According to Hrang Hkuma, "The most effective and most sustaining means, however, may be organizing small groups or house churches as is effectively done by many churches in Seoul, Korea. This is biblical and down-to-earth practical."4

The New Hope Community Church in Portland, Oregon, has the most effective cell ministry in America. This church has 485 cells with 4,800 persons in cell meetings. They .are called Tender Loving Care (TLC) cells. They do discipling, evangelism, and shepherding. They assemble to pray together, to study the Bible and apply it to their lives, and to share with one another. ${ }^{5}$

${ }^{1}$ Win Arn and Donald McGavran, How to Grow a Church (Glendale: Regal, 1973), 103.

${ }^{2}$ Ibid., 35 .

${ }^{3}$ Sumitara and Hkuma, 44.

${ }^{4}$ Ibid.

${ }^{5}$ Elmer L. Towns, An Inside Look at Ten of Today's Most Innovative Churches (Ventura: Regal, 1973), 78. 


\section{$\underline{\text { Revival }}$}

The psalmist asked God, "Wilt Thou not revive us again that Thy people may rejoice in thee?” (Ps 85:6). Patterson observed, “The Holy Spirit multiplies churches in movements called 'renewal,' 'revival,' 'restoration,' or 'outpouring of the Holy Spirit'-if we let Him continually renew us day by day." Zachariah observed, "Revival sanctifies and revitalizes the church. It thrusts the Church into action. Revival protects the Church against nominalism and lapsing into sin or paganism." Considering the important role revival plays in church growth, McGavran said, "Revival is like a head of steam in a railway engine. Without it the engine remains motionless. With it, plus rails, pistons, water, oil, timetables, engineer, and other elements, the engine travels widely and fast."

The importance of revival

Revival gives tremendous power to do the will of God. The Spirit of the Lord accomplishes the impossible in the lives of ordinary church members. When revival comes, sins are openly confessed and renounced. The Holy Spirit, through genuine revival, puts away evil habits such as covetousness, hatred, lust, and idolatry. New standards of justice and mercy are revived. ${ }^{4}$ As a gift of God, revival leads to confession

${ }^{1}$ George Patterson and Richard Scoggins, Church Multiplication Guide (Pasadena: William Carey, 1993), 7.

${ }^{2}$ Zachariah, "The Present Growth of the Assemblies of God," 279.

${ }^{3}$ McGavran, 180.

${ }^{4}$ Ibid. 
of sin and submission to God and ultimately leads to holy living. ${ }^{1}$

How revivals happen

James I. Packer provides the following elements of revival: “God comes close.”" The Holy God who cannot tolerate sin comes close in holiness. "Sin is seen." As a sharp and two-edged sword, the word of God pierces the heart of the people. When believers are revived, they love Jesus as never before. The Holy Spirit will effect a deep repentance and Christ will be the center of their lives. "The church becomes the people of the Presence,"य among whom the power of God is sensed. "The saints grow strong," love God, and become models in their faith. At the same time the devil will threaten, disrupt the church, and cause division. "Sinners are saved"6 by the power of God; evangelistic efforts are fruitful.

\section{Examples of revival}

A great revival movement came to many churches of Nagaland in 1976 . As a result, there was a growth in church membership, a desire to study the Word of God, doubling of the giving pattern, and awareness of the need to do cross-cultural mission.

${ }^{1}$ Tbid., 166-167.

2“'Jottings from J. I. Packer's Sermon on Revival," India Church Growth 2 (1989): 218.

${ }^{3}$ Ibid.

${ }^{4}$ Ibid.

${ }^{5}$ Ibid.

${ }^{6} \mathrm{Ibid}$. 
This revival emphasized spiritual gifts. One of the main emphases during this revival movement was the baptism of the Holy Spirit. ${ }^{1}$ As a result of the revival in Nagaland, there was an increase of offerings. Local evangelism and pastoral ministry were strengthened. Missionary interest was enhanced, and, finally, there was an improvement in theological studies. ${ }^{2}$

In 1892 there was a revival of Anglicanism at Kampala (Uganda, Africa). As a result, "the number of those taught in Anglican Catechism classes rose from 170 to 1600."3 There was another revival in 1906 at Buganda. Then in 1929, a great revival began in Rwanda that spread in the Anglican churches throughout all Uganda and from Uganda to other Protestant churches in Kenya, Tanzania, and Burundi. ${ }^{4}$

Regarding the revival in Burundi, Hohensee states, "The churches in Burundi demonstrated good growth when revival came because the people shared their faith in Christ with unsaved loved ones and neighbors." This revival gave them zeal to reach others for Christ. Because of the lay ministry, large numbers came to Christ.

In 1947, there was a great revival in Ao Baptist Churches, when Dr. and Mrs. Hunter came as missionaries to conduct revival meetings. Every night people prayed for

'A. O. Takatemjen, "Revival and the Nagaland Missionary Movement," India Church Growth 2 (1989): 217.

${ }^{2}$ Ibid.

${ }^{3}$ Gailyn Van Rheenen, Church Planting in Uganda: A Comparative Study (Pasadena: William Carey, 1976), 64.

${ }^{4}$ Ibid., 65.

${ }^{5}$ Donald Hohensee, Church Growth in Burundi (Pasadena: William Carey, 1939), 116. 
the presence of the Holy Spirit. Many lay members dedicated their lives to full-time evangelism. The local churches received a concern for perishing souls. The Bible was translated into the local language. Continuous prayer cells started. The church took an interest in the missionary enterprise, and the church membership increased considerably. ${ }^{1}$

It is said that "all the mighty spiritual revivals which constitute the mountain peaks of missionary annals had their roots in prayer." Powerful revivals and awakenings took place in China and Korea when small bands of believers prayed together regularly for the outpouring of the Holy Spirit. In Hawaii, due to the great awakening, in one day 1,700 were baptized and in six years 27,000 were added to the church. ${ }^{3}$

This chapter dealt with the biblical view of church growth in detail. A special emphasis was given to the expansion of the church as recorded in the book of Acts. The importance of the gospel commission is emphasized because it is the responsibility of each Christian to share the good news of salvation wherever he or she goes. Effective pastoral care, prayer ministry, inspiring worship services, small-group ministry, revival meetings, and lay training are the specific principles needed for Kottayam. The application of what has been learned thus far will begin with the following chapter.

'Nuklu Longkumer, The Growth of Baptist Churches among the Aos of Nagaland (Changtongya: Changtongya Baptists Church, 1998), 55-57.

${ }^{2}$ Robb, 111.

${ }^{3}$ Ibid., 111-112. 


\section{CHAPTER III}

\section{DESCRIPTION OF KOTTAYAM}

Kottayam is one of the fourteen districts of Kerala, a small state in the southwest corner of India. Kerala is the most literate, prosperous, and densely populated state of India. Kottayam is known as the land of latex and letters. According to the census of 1991, Kottayam stands in the tenth place in area and population in Kerala.' This chapter briefly narrates the history of Kottayam and describes the district, especially in terms of economy, education, medicine, culture, and religion.

\section{$\underline{\text { History }}$}

Phoenicians, Chinese, Romans, and Greeks had trade contacts with Kottayam even before the advent of Jesus Christ. Pliny, Ptolemy, and the author of Periplus referred in their writings to some landmarks in this area. In the first century A.D., Thomas, the apostle, is said to have established seven churches in Kerala, of which three were near Kottayam. ${ }^{2}$

From A.D. 800 to 1102 this area was under the kingship of the Kulashekara 629.

${ }^{1}$ K. M. Mathew, ed., Manorama Yearbook 1994 (Kottayam: Malayala Manorama, 1994),

${ }^{2}$ G. Krishnan, ed., A Peep into the History of Kottayam (Kottayam: Rohini Communications, 1997), 23. 
dynasty. In the eleventh century, with the decline of the Chera Kingdom, Kottayam was divided into two: Thekkumkoor and Vakdakkumkoor. The capital of Thekkumkoor was Vannimala and that of Vadakkumkoor was Kaduthuruthy. In the fourteenth century the capital of Thekkumkoor was transferred to the city of Kottayam. ${ }^{1}$

In the eighteenth century, Marthadavarma, the warrior prince, invaded this area and added it to his domains to establish the kingdom of Travancore. Until 1947, when India became independent, this area was under the rule of the Tranvancore kings. The Kottayam district derives its name from its main city. This name is a corruption of the Malayalam word Kottayakam, which means the interior of a fort. ${ }^{2}$

\section{$\underline{\text { Population }}$}

According to the 1991 census the total population of Kottayam was 1,828,271. The male population was 912,860 and the female was 915,411 . The density of population is 830 per square kilometer. ${ }^{3}$ The estimated population in 1998 was $2,008,000$ and in the year 2000 it was $2,062,000 .^{4}$

\section{$\underline{\text { Location and Climate }}$}

The boundaries of the Kottayam district are the Ernakulam and Idukki districts on

'Tbid.

${ }^{2}$ A. Sreedhara Menon, Kerala Districts Gazettes: Kottayam (Trivandrum: Kerala Gazetters, 1975), 1.

${ }^{3}$ V. B. Pyarelal, District Handbooks of Kerala: Kottayam (Trivandrum: Department of Public Relations, 1995), 4.

${ }^{4}$ Ibid., 33. 
the north, the Idukki district on the east, the Pathanamthitta district on the south, and the Allepy district and Lake Vembanad on the west. The area is 2,203 square kilometers. There are ninety-five villages and four municipalities in this district. The city of Kottayam is surrounded by rivers. ${ }^{1}$

The Periyar, the Moovattupuzha, the Manimala, and the Meenachil rivers flow through the Kottayam district. The first three are inter-district rivers, but the Meenachil flows entirely through the Kottayam district. ${ }^{2}$ Vembanad Lake forms the western boundary of this district. It is the largest lake in the state and its maximum length is 84 kilometers, with a maximum width of 14 kilometers. This lake is used for fishing, inland navigation, and collection of lime shell. ${ }^{3}$

Kottayam has a tropical humid climate with a hot season in the plains and sufficient rainfall throughout. The hot season is from March to May. From June to September the region gets the southwest monsoon. The post-monsoon or retreating season is in October and November. The rain ceases early in January. ${ }^{4}$

\section{$\underline{\text { Socioeconomic Situation }}$}

The socioeconomic situation of Kottayam is very significant.

${ }^{1}$ K. Baburaj, Kottayam Jilla Directory (Malayalam) (Kottayam: Jijo, 1997), 18.

${ }^{2}$ Menon, 7.

${ }^{3}$ Ibid., 10.

${ }^{4}$ Pyarelal, 3. 


\section{Agriculture}

Kottayam has good climate and fertile soil. The main cultivations include rubber, coconut, rice, pepper, banana, and ginger. According to the Plantation Labor Act, there are 4,614.71 hectares of rubber estates in this district. Kottayam is known as the land of "latex" because of its rubber production. The pepper produced at Pala attracts world markets. In addition coffee, cocoa, vegetables, and fruits such as mangoes, jackfruit, and pineapples are produced. ${ }^{1}$

Farming is the livelihood of the majority of the people. Moreover, it is a major factor that influences the economy of this district. Food crops, as well as cash crops, are cultivated. Rice and tapioca are the main food crops cultivated. Vegetables and pineapple are also cultivated. Rubber, coconut, and pepper are the main cash crops. Each year 105,198 metric tons of rubber are produced. ${ }^{2}$

\section{Transportation}

Kottayam has three main transportation systems: road, boat, and railway. Roads were first built for the travel of the army. In 1877-1878 the main central road was built by Sir C. P. Ramaswami Iyer; it covers 243 kilometers from Trivandrum to Angamaly and passes through Kottayam. In 1885 the Kottayam Kumily road, from Kottayam to the hill station of Kumily $(110 \mathrm{kms})$, was completed. Today there are roads to all other districts and to Madurai, Bangalore, and Mumbai from Kottayam. In 1856 the railway

\footnotetext{
${ }^{1}$ Baburaj, 39.

${ }^{2}$ Pyarelal, 5.
} 
started at Kottayam; today, there are trains to all the major cities of India from this place. ${ }^{1}$

Trade

The spices of Kerala have always attracted the attention of foreign nations. The desire to enrich themselves by the trade in these articles brought the Europeans to Kerala. Kottayam is close to Cochin Harbour and Alleppy Port. The exporting of rubber, tea, pepper, ginger, and cardamom has given Kottayam its commercial importance.

Through five-year plans trade in Kottayam has progressed. Travancore Cement at Nattakam is a leading trade unit. Travancore Electro Chemicals at Chigavanam, Hindustan Paper at Velloor, Madras Rubber at Vadavathoor, and the Kottayam Textiles at Vedagiri are prominent trade units of this district. There are a number of leading rubber companies such as Paragon, Eva, Hawaii, Kingswear, and Prima. In 1994-95 there were 1,154 factories and 13,146 mini-industrial units in the Kottayam District. ${ }^{2}$

The milk pasteurization center at Vadavathoor, the K. S. Cattle Feed Manufacturing Company at Vedagiri, and the Planta Meal Manure Manufacturing Centre are other leading trade units of this district. The Rubber Board and Oil Palm in India have their all-India headquarters at Kottayam. ${ }^{3}$

\section{Industry}

Kottayam has a significant industrial sector. There are 11 large-scale industries,

${ }^{1}$ Baburaj, 60.

${ }^{2}$ Ibid., 37.

${ }^{3}$ Ibid., 38. 
12 mini-industries, and 1,200 small-scale industrial units. The rubber-based industrial units that manufacture latex, crepe rubber, and footwear are remarkable. The availability of soft wood and other timbers in the forest helps many industries such as plywood, packing cases, splints and veneers, and furniture. ${ }^{1}$

The coir industry, which processes the fiber of the coconut husk, provides work to the largest section of the working class in the Kottayam District; it plays a significant role in the economy of the district. It is estimated that over 30,000 people are engaged in the coir industry. Vaickom is the main center of this industry, for "there are sufficient saline water sources to soak the green coconut husks in all seasons." All along the banks of the Vambanad lake, women and children beat rotten husks to get the golden fibers. This fiber is spun into yarn, and known as the "Vaickom yarn," much in demand in the coir market throughout the world. ${ }^{2}$

\section{Publishing}

Kottayam is known as the land of letters. It produces the greatest number of papers and books in the state. The first printing press in Malayalam was the Christian Missionary Society Press started in 1821 at Kottayam. The first Malayalam newspaper, Jnana Nikshepam, was started in 1848 . The first women's magazine, Vanithamithram, by P. C. Korath, was from Kottayam. D. C. Books and Sahitya Pravarthaka Sahakarana Sangam are the two largest publishers of books in Malayam. The first computer science

\footnotetext{
'Pyarelal, 8.

${ }^{2}$ Menon, 193.
} 
magazine in Malayalam, Mayuram, is also from Kottayam. ${ }^{1}$

On July 20, 1996, the Indian Express published the article "Kottayam Thriving as Publishing Capital of Kerala," by O. J. George. It affirmed that this small town was the publishing capital of Kerala. "Apart from the dailies being published from Kottayam, this town is also the nerve center of book publishing industry. . . . All the dailies also publish weeklies for the ordinary people. Some stress on sports, agriculture, films, cartoons, etc."2 Eighty percent of the publications of Kerala come from Kottayam.

The five leading newspapers in Malayalam-the Malayala Manorama, Deepika, Mangalam. Mathrubhumi, and Deshabhimani-are published in Kottayam. ${ }^{3}$ Table 1 shows some of the Malayala Manorama publications.

Deepika and Magalam also publish similar magazines and weeklies for women and children. Besides these, there are papers of different religious groups. Kandathil Varghese Mappila, K. C. Mannen Mappila, K. M. Cherian, and K. M. Mathew are leading journalists of Kottayam. ${ }^{4}$

In 1821 Benjamin Bailey started the first Malayalam printing press of Kerala at Kottayam. The first Malayalam-English dictionary was published in Kottayam in 1846. The first Malayalam Bible was published in this place. The first encyclopedia in Malayalam was published in Kottayam. Vaettom Mani's Puranic Encyclopedia was

${ }^{1}$ Baburaj, 21.

${ }^{2} \mathrm{O}$. J. George, "Kottayam Thriving as Publishing Capital of Kerala," The Indian Express, July $20,1996,7$.

${ }^{3}$ Baburaj, 53.

${ }^{4}$ Ibid., 21. 
published there. $^{1}$

\section{TABLE I}

MALAYALA MANORAMA PUBLICATIONS

Title

Description

1. Malayala Manorama

Daily

2. Manorama

Weekly (general)

3. Vanitha

Bimonthly for women

4. Bala Rema

5. Balarema Amarchitra Katha

For children

6. Bhashaposhini

Pictorial stories for children

7. Kalikudukka

Educational magazine

8. Manorama Year Book

Cartoons for children

9. Karshakasree

10. Vijaya Veedhi

11. The Week

Both Malayalam and English

Farmers' magazine

Exam preparation for $10^{\text {th }}$ standard students

English magazine

12. Thozhil Veedhi

Professional magazine

Source: Kottayam Baburaj, ed., Kottayam Jilla Directory (Malayalam) (Kottayam: Jijo, 1997), 53.

\section{Banking}

In the district there are twenty-four scheduled banks with 260 branches and extension counters. Besides these, there are many cooperative banks: Kottayam District Cooperative Bank has forty-three branches.

${ }^{1}$ Ibid., 21. 


\section{Education}

According to 1991 Kameshumari Statistics, the literacy rate in India is $\mathbf{5 2 . 2 1}$ percent; that in Kerala is 89.81 percent, while Kottayam boasts 95.72 percent. $^{1}$

\section{Schools}

In the field of education for women, the contribution of missionaries was remarkable. Christian missionaries commenced female education in this district. The pioneer in this field was Mrs. Bailey; in 1816 she gave instruction to a few girls in her own house, providing free boarding and lodging. In 1827 Mrs. Fenn and Mrs. Baker opened a girls' school at Kottayam. Mrs. Baker's school today is a memorial to the early pioneers in the field of female education in this district. ${ }^{2}$ The Christian Missionary Society (CMS) missionaries started education which enrolled all castes. All sat together in the school and this opened a new era in the history of Kottayam.

In 1821 CMS missionaries started a grammar school at Kottayam. This became the CMS College, today the oldest college in Kerala. There are 920 schools, five Bachelor of Education colleges, thirty-six other colleges, two schools of medicine, two schools of technology and applied sciences, a school of communication and information science, a school of applied mathematics, a school of environmental science, a college of law, a school of sports and physical education, two government polytechnics, twenty-

'Pyarelal, 9.

${ }^{2}$ Menon, 428. 
seven industrial training institutes, and ten teacher training institutes. ${ }^{1}$

\section{Libraries}

The missionaries and the CMS educated the town people with the help of Dhivan Rama Rao, who started the Kottayam Public Library in 1882. It has a collection of 125,000 books. In 1972 , a children's library was attached to it with 14,000 books for children. There are 382 libraries in this district. ${ }^{2}$

\section{Medical Facilities}

There are 69 government hospitals, 47 Ayurvedic hospitals, 37 homeopathic hospitals, 60 naturopathy centers, and 131 mercy homes in this district. Kerala's third medical college was established at Kottayam in 1962, and the hospital in $1970 .^{3}$ This medical college hospital has 1,101 beds with seventeen major and four minor operation theaters and a modern blood bank facility. All modern treatment facilities are available here, including the ultra modern whole body scanning system, open-heart surgery, and cancer care center. ${ }^{4}$

\section{$\underline{\text { Culture }}$}

Kottayam is rich in its traditional values for its contribution in art and architecture. The first lady doctor of Kerala, Mary Punnan Lukose, and the first lady

${ }^{1}$ Baburaj, 375-378.

${ }^{2}$ Pyarelal, 15.

${ }^{3}$ Baburaj, 37.

${ }^{4}$ Pyarelal, 11. 
advocate and judge, Anna Chandy, were from Kottayam.

\section{Tourism}

As Pyarelal observes, "Kottayam with its landscape, rivers, lakes, bird sanctuaries, temples, churches, mosques, and historic remnants attract tourists."1 Kumarakam is a small village west of Kottayam town known as "Wonderland" lying below sea level. The bird sanctuary of Kumarakam has birds such as egrets, darters, herons, teal, waterfowl, cuckoo, and wild ducks in abundance. Moreover, Siberian storks and other migrating birds are seen in every season. ${ }^{2}$

The following features add prominence to Kottayam. The Indian President K. R. Narayan hails from this district. India's famous Hindu pilgrim center of Sabari Mala is near Kottayam. Dakashina Mookambika, the famous Saraswathi Temple of South India, is in Kottayam. South India's Adityapuram Sun Temple is in this district. The political party Kerala Congress originated from Kottayam. The Head Office of Mahatma Gandhi University is in Kottayam. A few churches attract pilgrims: Manarkad, Puthappaly, and Aruvithura.

\section{Marriage Customs and Rituals}

Marriage customs and rituals vary among the different religious communities. The giving of cloth by the groom to the bride is essential to the marriage of Hindu people

'Tbid., 25.

${ }^{2}$ Ibid. 
and this ceremony is called Pudava Koda. ${ }^{1}$ This custom is practiced even among the Christians. Tying the tali is common among the Hindus and Christians as a wedding sign. The dowry system is still prevalent: "The dowry system has been prevalent among all communities and castes in this district-Hindus, Christians, and Muslims. It is paid by the parents of the bride either in cash or in the form of gold or jewelry or vessels or property."2

\section{Dance}

Kathakali, a native dance of Kerala, is frequently performed in and around Kottayam. The dancers interpret Puranic stories through mime and gesture. The revival of traditional arts in India has now raised Kathakali to high national and international esteem. Thullal is another dance form in which the dancer sings to the accompaniment of a simple form of dance. " "Chakiar koothu is an entirely different art where Puranic stories are interpreted by an actor very proficient in Sanskrit and dramatic gestures. ${ }^{\circ}$

\section{Boating}

Boat races are common to Kottayam during the festival seasons, especially during Onam, which is the harvest festival that falls in August or September. In the Kumarakom

'Menon, 81.

${ }^{2}$ Ibid., 83.

${ }^{3}$ Ibid.

${ }^{4}$ Ibid. 
boat race, about 50 types of boats participate. Besides this, "traditional cargo boats called Kettuvallams are modified into cruise boats and house boats, with all basic facilities like kitchen, toilet, bathrooms, sit outs etc.," they move around the back waters of Vembanad lake. ${ }^{1}$

\section{Social Institutions}

The YMCA was established at Kottayam in 1870 by a missionary named J. Thompson. The YWCA was established in 1933 and Mrs. C. K. Jacob was its first president. The Red Cross Society started to function in 1950. It takes care of relief work, provides financial help for poor patients, with the motto of "maximum service." The Rotary Club was organized in 1951; it has provided houses for many poor people. In 1961 the Lions' Club was established with a slogan, "We serve." It has provided many houses for the poor and the casualty building of the district hospital. ${ }^{2}$

\section{$\underline{\text { Religion }}$}

Kottayam is a Christian-dominated area. The world headquarters of the Malankara Orthodox Syrian Church and its Catholicate office are in Kottayam. The Knanaya Church also has its headquarters in this place. ${ }^{3}$

Missionaries arrived in the nineteenth century. "Rev. Benjamin Bailey who arrived in 1817 was the first missionary who settled down in Kottayam. Soon Rev.

'Pyarelal, 26.

${ }^{2}$ Krishnan, 61.

${ }^{3}$ Ibid., 19. 
Joseph Fenn and Rev. Henry Baker followed him. These three English men identified themselves so much with Kottayam and they were known as 'The Kottayam Trio.'

\section{Christianity}

The Valiapalli (big church) situated in Kottayam town was constructed in 1550. The very ancient Persian cross with primitive scripts enshrined in it attracts many people. $^{2}$ The Vimalagiri Church, "constructed in Gothic style, is an example of excellence in architectural beauty. The main steeple has a height of $172 \mathrm{feet}$, which is considered as the highest church steeple in the state." ${ }^{\prime 3}$ The CSI Cathedral is a monument of the British era. The old Marthoma Seminary and Vadavathoor Seminary are manifestations of Syrian and Roman traditions of architecture. ${ }^{4}$

The Christian presence of this district is greater than in other districts of Kerala. Table 2 shows the number of Christian churches in Kottayam.

\section{Hinduism}

There are about 800 Hindu temples in the district: 274 temples are devoted to goddesses, 125 to Siva, 96 to Sri Krishna, 93 to Sastha, and 40 to Subramaniam. According to the census of 1981 , there were 807,014 Hindus in this district. The Hindus $1971,171$.

'M. M. John, “CMS Missionaries," Kottayam Municipality Golden Jubilee Souvenir,

${ }^{2}$ Krishnan, 18.

${ }^{3}$ Pyarelal, 22.

${ }^{4}$ Krishnan, 18. 
have their own schools and colleges. The Nair Service Society College is a famous

Hindu college. The annual festival of the Thirunakkara Temple in the heart of Kottayam falls in the month of March. It is a momentous occasion for all classes of people and attracts large crowds. ${ }^{1}$

TABLE 2

CHRISTIAN CHURCHES IN THE KOTTAYAM DISTRICT

Episcopal Churches

Non-Episcopal Churches

1. Catholics

486

2. C.S.I.

141

3. Orthodox

94

4. Jacobites

58

5. Marthomites

37

6. C.M.S.

35

7. Knanaya

13

8. Ecumenical 1

Total

865

Total

371

Source: Kottayam Baburaj, ed., Kottayam Jilla Directory (Malayalam)

(Kottayam: Jijo, 1997), 473.

\section{Islam}

According to the census of 1981 , there were 84,217 Muslims in the Kottayam

District. There are 116 institutions for them in this district. Erattupetta is a Muslimdominated area. The Thazhathagady Juma Masjid of Kottayam is one of the ancient Mosques of India, over 1,000 years old. It exemplifies Malabar Muslim architecture with a tiled gabled roof. ${ }^{2}$

'Ibid., 559.

${ }^{2}$ Baburaj, 411. 


\section{CHAPTER IV}

\section{DESCRIPTION OF THE THREE SDA CHURCHES IN KOTTAYAM}

In this chapter three Adventist churches in Kottayam are described. They are Kottayam, Areeparambu, and Kurichy. The Kottayam Church is in the city and the other two are in rural areas. Their growth in the last ten years is reported.

\section{$\underline{\text { Kottayam Church }}$}

History of the Church

Adventist work started at Kottayam immediately after the establishment of the Vadavathoor church in 1932. In 1934 the late L. G. Mukerii, Dr. K. C. David, and S. N. David conducted a major evangelistic program in Kottayam and fourteen people were baptized. Again in 1936, from March 15 to April 27, another series of meetings was conducted near Malayala Manorama Press by Pastor S. Nathaniel, Dr. K.C. David, and Pastor S. N. David. As a result, a few more joined the church. But there was not yet a place of worship in Kottayam, so the members attended Vadavathoor Church, which was $8 \mathrm{~km}$ from the town.

In 1956, beginning September 26, another series of evangelistic meetings was conducted by Pastors Broderson, P. S. Johnson, and M. A. James; eight people were baptized. Under the leadership of Pastor K. P. Kurian, in September 1957, another evangelistic meeting was conducted and seventy people were baptized. On November 29 
1958, W. Maywald, then Union Home Missionary Secretary, organized the church in a rented building. Later, a piece of land was purchased near the railway cutting and near the Holy Family School. In 1969 M. A. James and John P. Thomas conducted another series of meetings and over one hundred were baptized. When the membership increased, the church leaders sold that property and purchased land in the heart of the town near the District Headquarters in 1972. When O. M. George was pastoring this church, a beautiful church building was constructed under the supervision of C. K. Kurian, a lay member.

T. P. Kurian and Mrs. Annie Esau are professors in Spicer Memorial College. Sunny K. John and John P. Thoms are pastors in this mission field.

\section{Growth Patterns}

In this section the growth patters for the years 1987 through 1997 are described and analyzed. Table 3 shows the statistics for membership and attendance for those years.

Figure 1 shows the composite membership, which is calculated by adding the number of church members, the number of Sabbath School members, and church attendance and then dividing by three. The composite membership of the Kottayam Church in 1987 was 45 . The membership has increased gradually with a steady growth to 90 in 1997. 
TABLE 3

MEMBERSHIP STATISTICS, 1987 - 1997, KOTTAYAM CHURCH

\begin{tabular}{|c|c|c|c|c|c|c|c|c|c|c|c|}
\hline & 1987 & 1988 & 1989 & 1990 & 1991 & 1992 & 1993 & 1994 & 1995 & 1996 & 1997 \\
\hline 1. Membership & 50 & 50 & 54 & 52 & 56 & 60 & 66 & 70 & 75 & 80 & 85 \\
\hline 2. S S Attendance & 35 & 38 & 40 & 45 & 50 & 50 & 55 & 60 & 65 & 70 & 75 \\
\hline 3. Church Attn & 50 & 55 & 61 & 65 & 70 & 76 & 80 & 86 & 90 & 100 & 110 \\
\hline 4. Baptisms & 3 & 4 & 5 & 5 & 6 & 7 & 7 & 8 & 8 & 10 & 12 \\
\hline 5. Bapt - Non-SDAs & 3 & 2 & 5 & 4 & 6 & 5 & 5 & 6 & 5 & 8 & 10 \\
\hline 6. Bapt - SDA Childn & 0 & 2 & 0 & 1 & 0 & 2 & 2 & 2 & 3 & 2 & 2 \\
\hline 7. Transfers In & 0 & 2 & 0 & 2 & 2 & 2 & 0 & 2 & 2 & 0 & 0 \\
\hline 8. Transfers Out & 2 & 0 & 4 & 0 & 2 & 0 & 0 & 1 & 2 & 2 & 2 \\
\hline 9. Deaths & 1 & 0 & 1 & 1 & 0 & 1 & 0 & 1 & 1 & 0 & 0 \\
\hline 10. Members Dropped & 0 & 2 & 2 & 2 & 2 & 2 & 3 & 3 & 2 & 5 & 5 \\
\hline 11. Comp Membershp & 45 & 47 & 51 & 54 & 58 & 62 & 66 & 72 & 76 & 83 & 90 \\
\hline
\end{tabular}




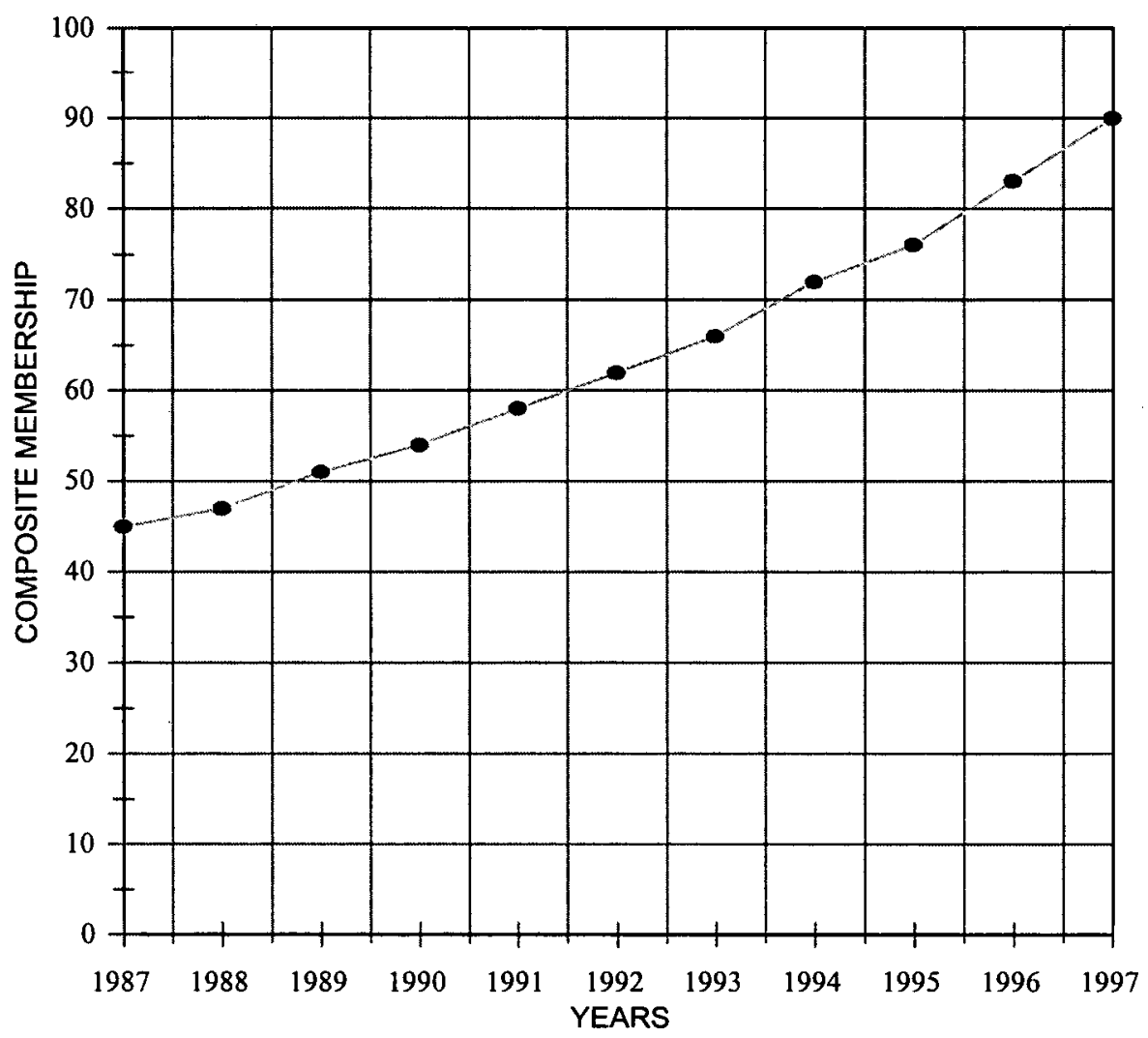

\begin{tabular}{||l|c|c|c|c|c|c|c|c|c|c|c||}
\hline Years & 1987 & 1988 & 1989 & 1990 & 1991 & 1992 & 1993 & 1994 & 1995 & 1996 & 1997 \\
\hline Members & 45 & 47 & 51 & 54 & 58 & 62 & 66 & 72 & 76 & 83 & 90 \\
\hline
\end{tabular}

Figure 1. Composite membership, 1987-1997, SDA Church, Kottayam. 
Figure 2 shows the decadal growth rate of the Kottayam Church. There has been a steady increase in the number of active members. In 1987 the membership was 50, but by 1997 the church had grown to 110 members. This represents a 120 percent growth.

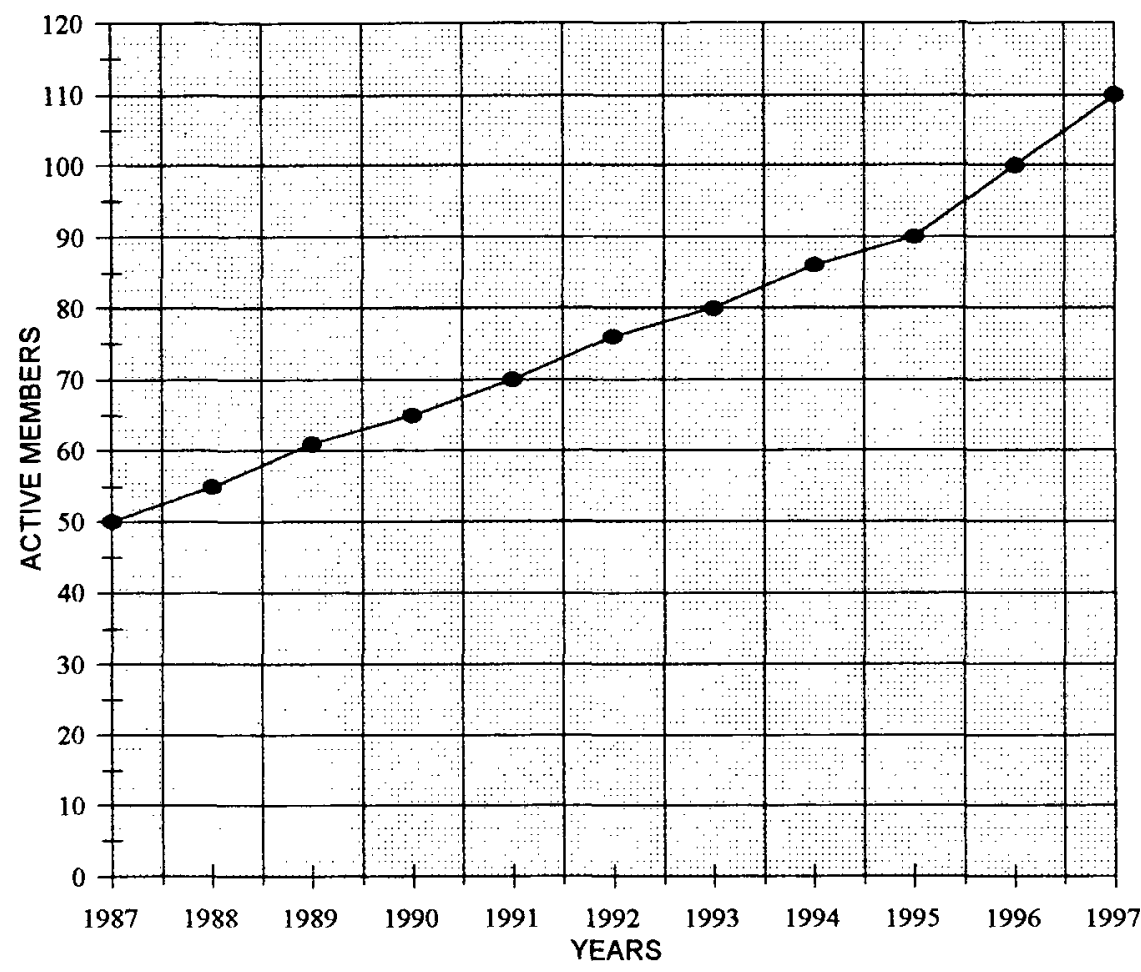

\begin{tabular}{||l|c|c|c|c|c|c|c|c|c|c|c|c|}
\hline Years & 1987 & 1988 & 1989 & 1990 & 1991 & 1992 & 1993 & 1994 & 1995 & 1996 & 1997 \\
\hline Members & 50 & 55 & 61 & 65 & 70 & 76 & 80 & 86 & 90 & 100 & 110 \\
\hline
\end{tabular}

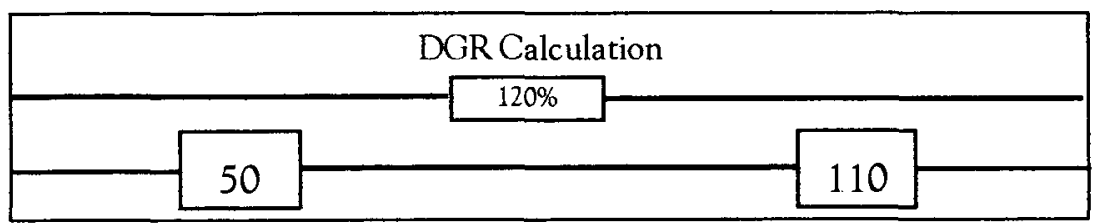

Figure 2. Decadal growth rate, Kottayam Church. 
Figure 3 shows the annual growth rate of the membership of the Kottayam Church. Compared to 1983 , the growth rate was lower from 1989 to 1994 . In 1995 and 1996 there was an increase.

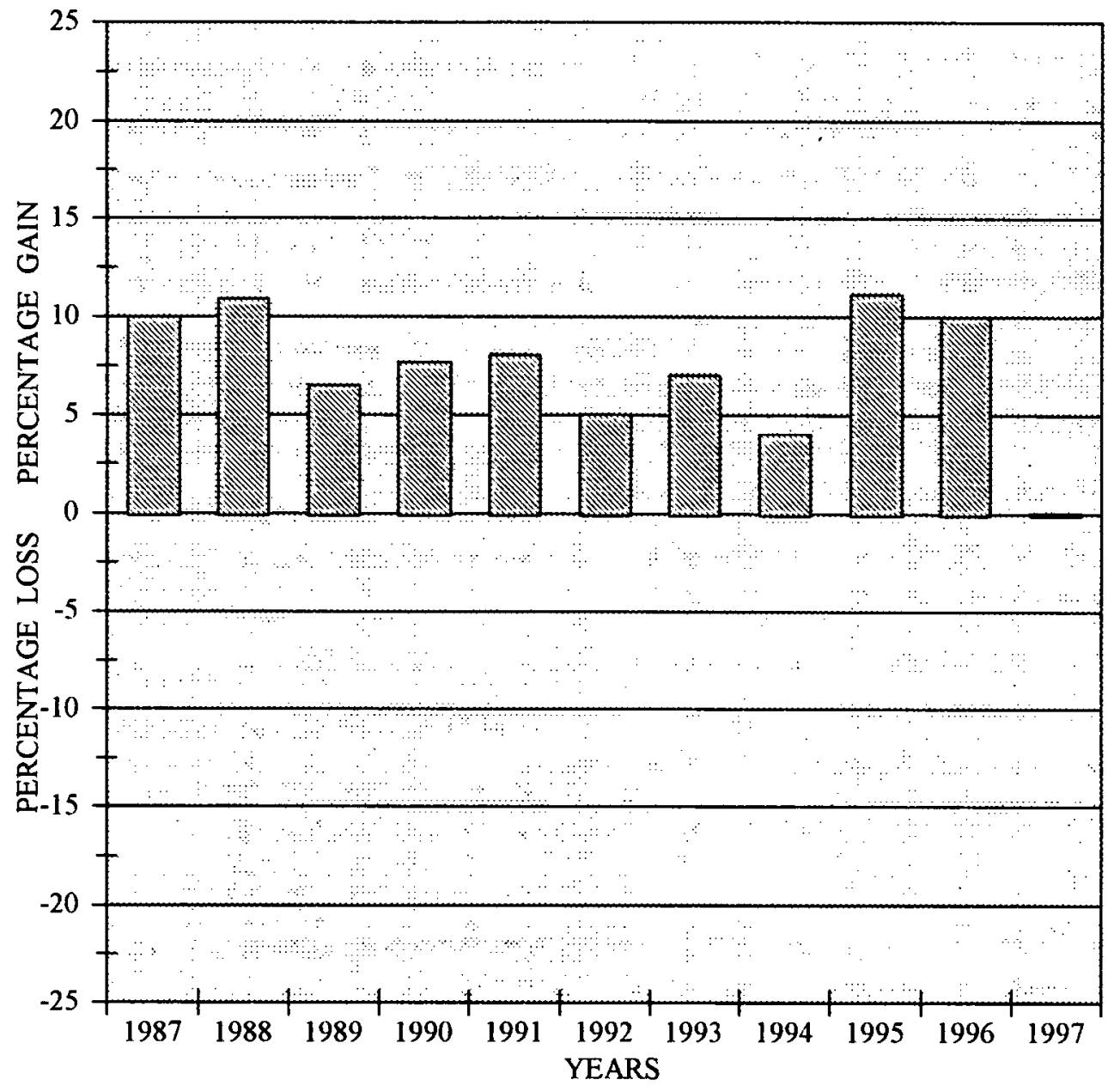

\begin{tabular}{||c|c|c|c|c|c|c|c|c|c|c|c|}
\hline Year & 1987 & 1988 & 1989 & 1990 & 1991 & 1992 & 1993 & 1994 & 1995 & 1996 & 1997 \\
\hline AGR & 10 & 10.9 & 6.56 & 7.69 & 8.6 & 5.3 & 7.5 & 4.65 & 11.1 & 10 & - \\
\hline
\end{tabular}

Figure 3. Annual growth rate of SDA Church, Kottayam. 
Figure 4 shows the faith projection for the Kottayam Church. It is estimated that by 2002 the membership should be 160 with a D.G.R. of 78 percent.

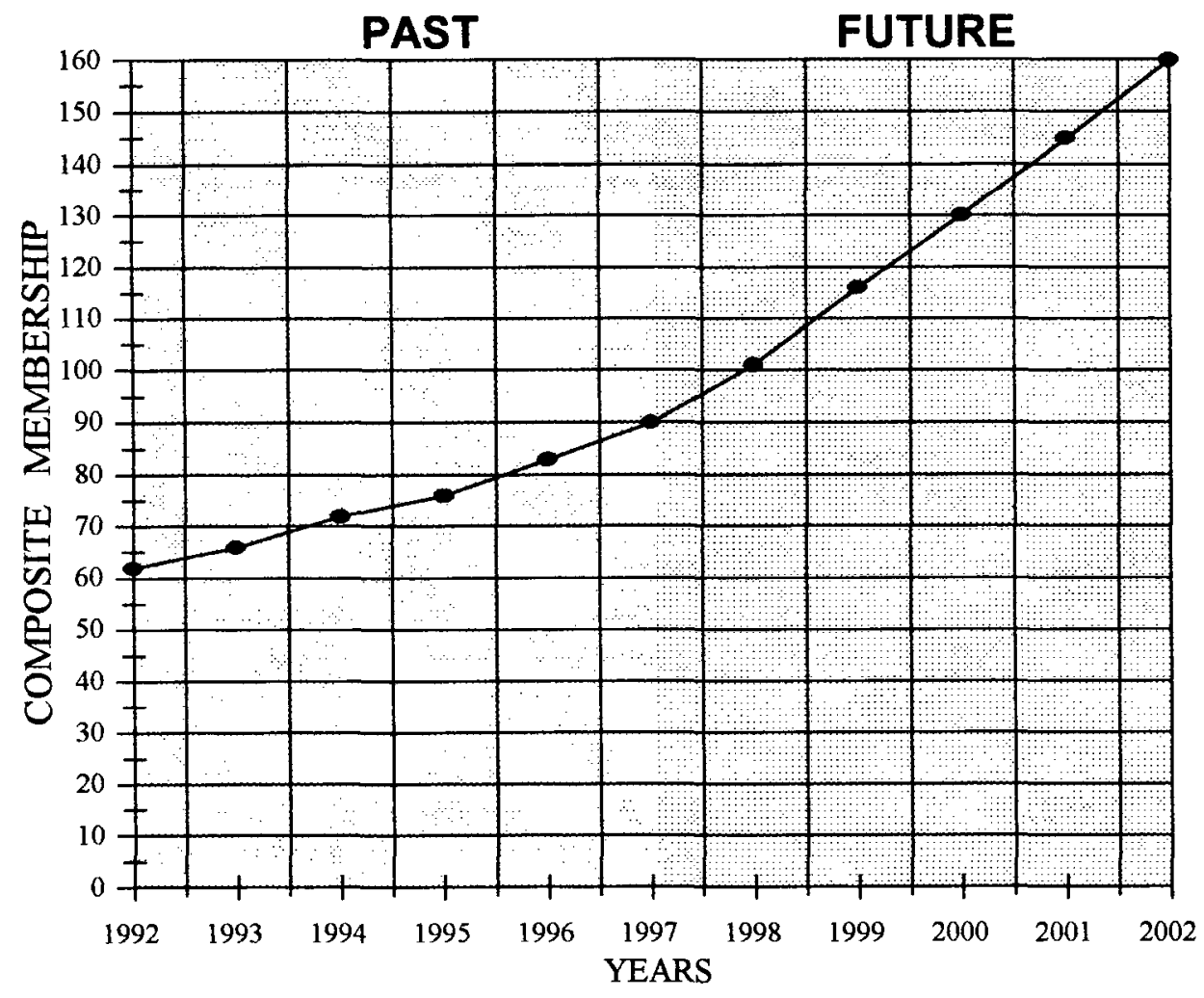

\begin{tabular}{|lrrr|}
\hline Year & 1992 & 1997 & 2002 \\
Members & 62 & 90 & 160 \\
\hline
\end{tabular}

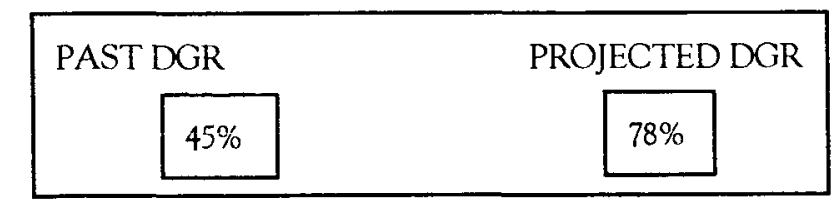

\begin{tabular}{|l|c|c|c|c|c|}
\hline YEARS & 1998 & 1999 & 2000 & 2001 & 2002 \\
\hline MEMBERSHIP & 102 & 116 & 130 & 145 & 160 \\
\hline
\end{tabular}

Figure 4. Faith projection, SDA Church, Kottayam. 
This is a growing church. From 1987 to 1996 there were 63 baptisms, of which 48 were from non-SDA families and only 15 were Adventist members' children. Transfers in and out were more or less even. When 29 dropped out by death and apostasy, 63 came in by baptism. So, compared to baptisms, apostasy is low.

\section{Factors Contributing to the Growth}

\section{$\underline{\text { Pastor Not Transferred }}$}

A vital factor in the growth of Kottayam Church was that Pastor D. Paulose was able to provide strong leadership for this church for ten years. He was able to understand the situation and adapt to it. As a result, the church grew in membership as well as finances.

\section{Inspiring Worship Services}

The worship services were interesting and the church was able to maintain a spiritual atmosphere. After attending the worship service, visitors would anxiously wait for the following Sabbath to visit again. Both the Sabbath School and the divine service are well planned and appealing to the worshipers. The song service is lively. There has been revival in the church. Every Sabbath there is fasting and prayer for the sick people, which continues until 4:00 p.m. This is a blessing to the church as well as the community. Many sick people have been healed; even non-Adventists bring their sick people and the healing ministry has helped the growth of this church.

\section{Church Unity}

The membership of this church comprises a multi-caste group. Though they live 
far from the church, on Sabbath all come together in one accord. Each member contributes to the unity of the church. They do not quarrel over minor things, for they believe in the ministry of reconciliation.

\section{Witnessing}

A lay member named Thomaskutty preaches with a megaphone every morning from 4:00 to 6:30. Every week he walks 12 to 15 kilometers to witness. He is a good singer and many are interested in his singing. If he misses one day, the people inquire about his absence. After singing a few songs, he preaches on a fundamental doctrine of the church. Through this brother's ministry five people have joined the church. He still continues the megaphone ministry.

\section{Fellowship Meetings}

The Kottayam Church conducts quarterly fellowship meetings without fail. All the members take part in this joyful occasion and make it a blessing to everyone. The fellowship meal closes the program.

\section{Vacation Bible School}

The members of one family have conducted Vacation Bible School every year since 1982. Through their ministry many have come to know about Adventist teachings.

\section{Youth Witnessing}

The Kottayam Church has some active young people. They witness about Christ to their classmates and to the professors in their college. Many of the college professors know about the Sabbath. 


\section{Areeparambu Church}

History of the Church

Areeparambu is a village located 13 kilometres from Kottayam. In the eastern part of Kottayam town the Adventist work was started by the interest of a lay member, Joseph Nadayil, who was formerly a Roman Catholic. He had a desire to preach the Adventist message in his village and mentioned it to someone who worked at the church headquarters. Beginning August 22, 1978, the late Pastor M. U. Thomas, then ministerial secretary of the mission, conducted a series of evangelistic meetings with the help of pastors K. C. Markose, P. J. Mathai, K. M. Joseph, and A. I. Samuel. The meetings continued for three months. As a result, 98 people were baptized from different denominations and religions. Pastor Chacko Devasia, one of the leading evangelists of this section, is a product of this church. The church has its own building, which was constructed in 1980 .

\section{Growth Patterns}

In this section, growth patterns for 1987 through 1997 are presented. Table 4 shows membership statistics for the Areeparambu Church from 1987 through 1997. A slow growth pattern is evident. 
TABLE 4

MEMBERSHIP STATISTICS, 1987-1997

AREEPARAMBU CHURCH

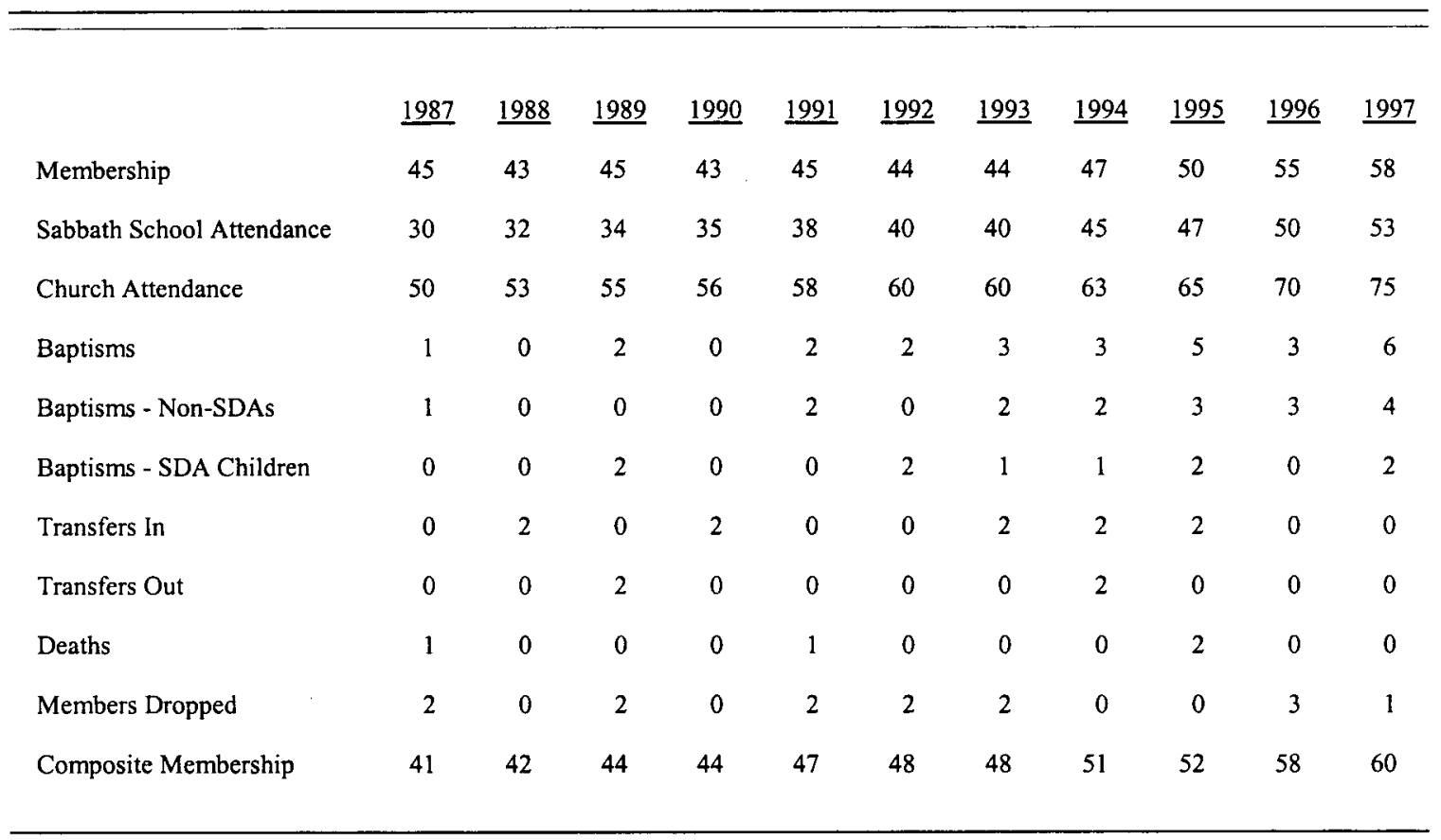


Figure 5 shows the growth of the composite membership of the Areeparambu Church. The composite membership of this church in 1987 was 36 , and there was a slight growth in 1988 and no growth in 1989. From 1990 to 1993 the growth rate was very slow; each year only one member was added. From 1995 onwards, this church began to grow as a result of lay ministry. If this church continues in the same spirit, there will be a good growth by A.D. 2000.

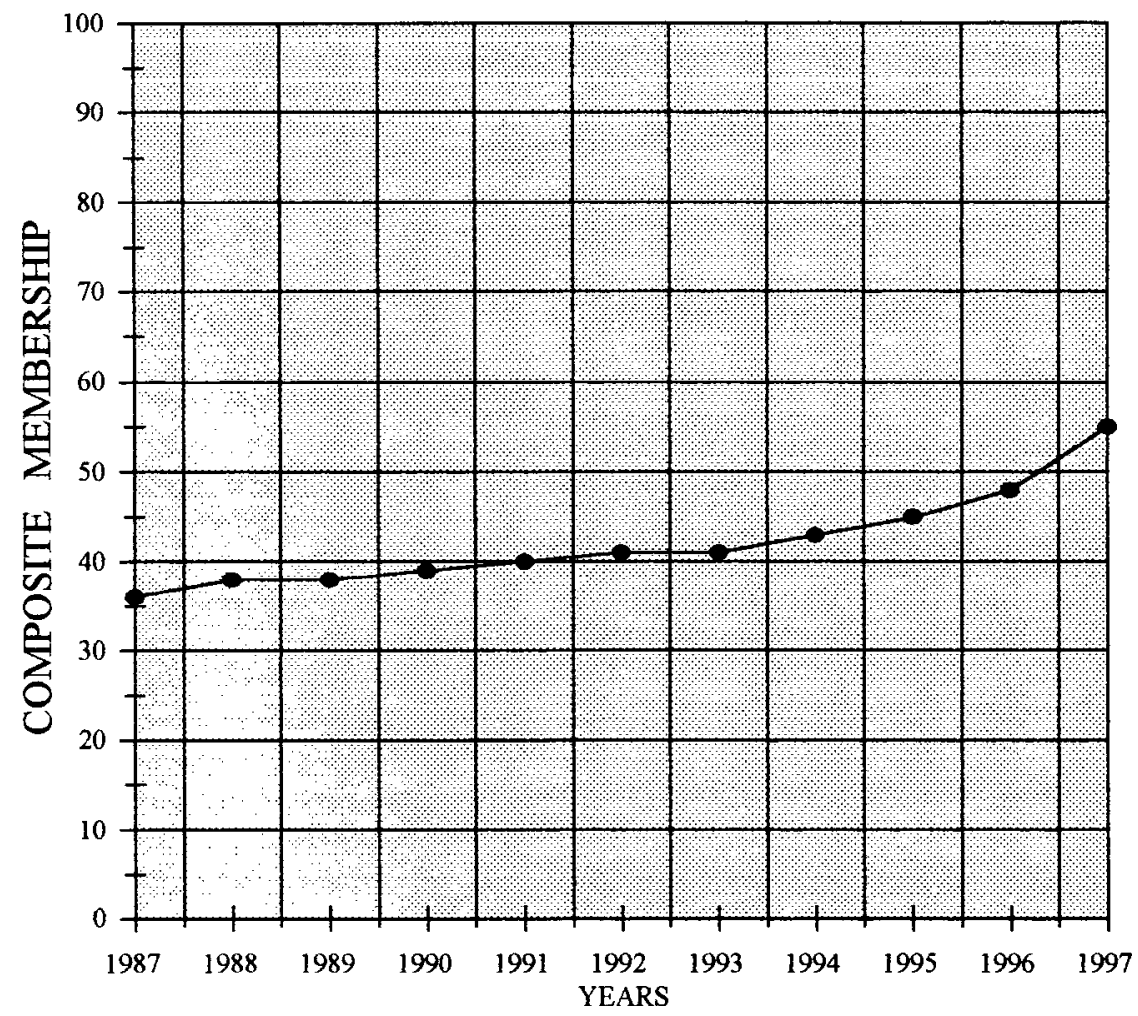

\begin{tabular}{|l|c|c|c|c|c|c|c|c|c|c|c|}
\hline Years & 1987 & 1988 & 1989 & 1990 & 1991 & 1992 & 1993 & 1994 & 1995 & 1996 & 1997 \\
\hline Members & 36 & $\mathbf{3 8}$ & 38 & 39 & 40 & 41 & 41 & 43 & 45 & 48 & 55 \\
\hline
\end{tabular}

Figure 5. Composite Membership Growth, Areeparambu Church 
Figure 6 shows a lack of growth in the number of active members of Areeparambu Church. In 1988 and 1989, only one member was added; and in 1990 and 1991 there was no increase. From 1993 onwards there has been a slight increase. In 1987 the membership was 45 , and by 1997 it was 65 , which shows 44 percent decadal growth.

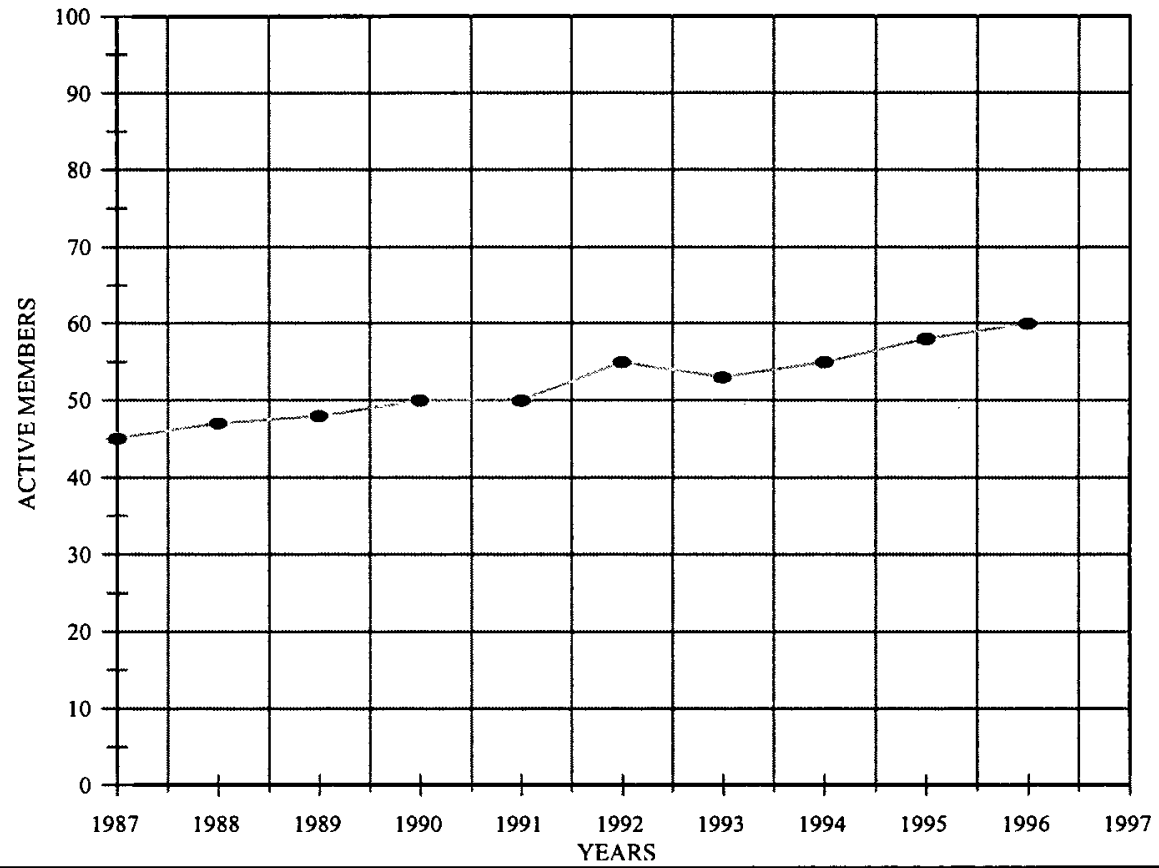

\begin{tabular}{||l|c|c|c|c|c|c|c|c|c|c|c||}
\hline Year & 1987 & 1988 & 1989 & 1990 & 1991 & 1992 & 1993 & 1994 & 1995 & 1996 & 1997 \\
\hline Members & 45 & 47 & 48 & 50 & 50 & 52 & 53 & 55 & 58 & 60 & 65 \\
\hline
\end{tabular}

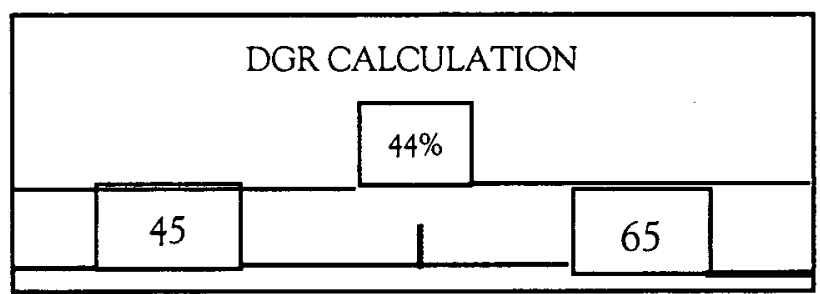

Figure 6. Decadal growth rate, SDA Church, Areeparambu. 
Figure 7 shows the annual growth rate of the membership of the Areeparambu Church. The growth in 1988 was less than in 1987, but in 1989 there was a slight increase. In 1990 there was no increase at all because of the change of pastor and the lack of lay involvement in evangelism. In 1991, there was slight growth, but in 1992 the growth dropped. From 1993 to 1995 the growth rate was low.

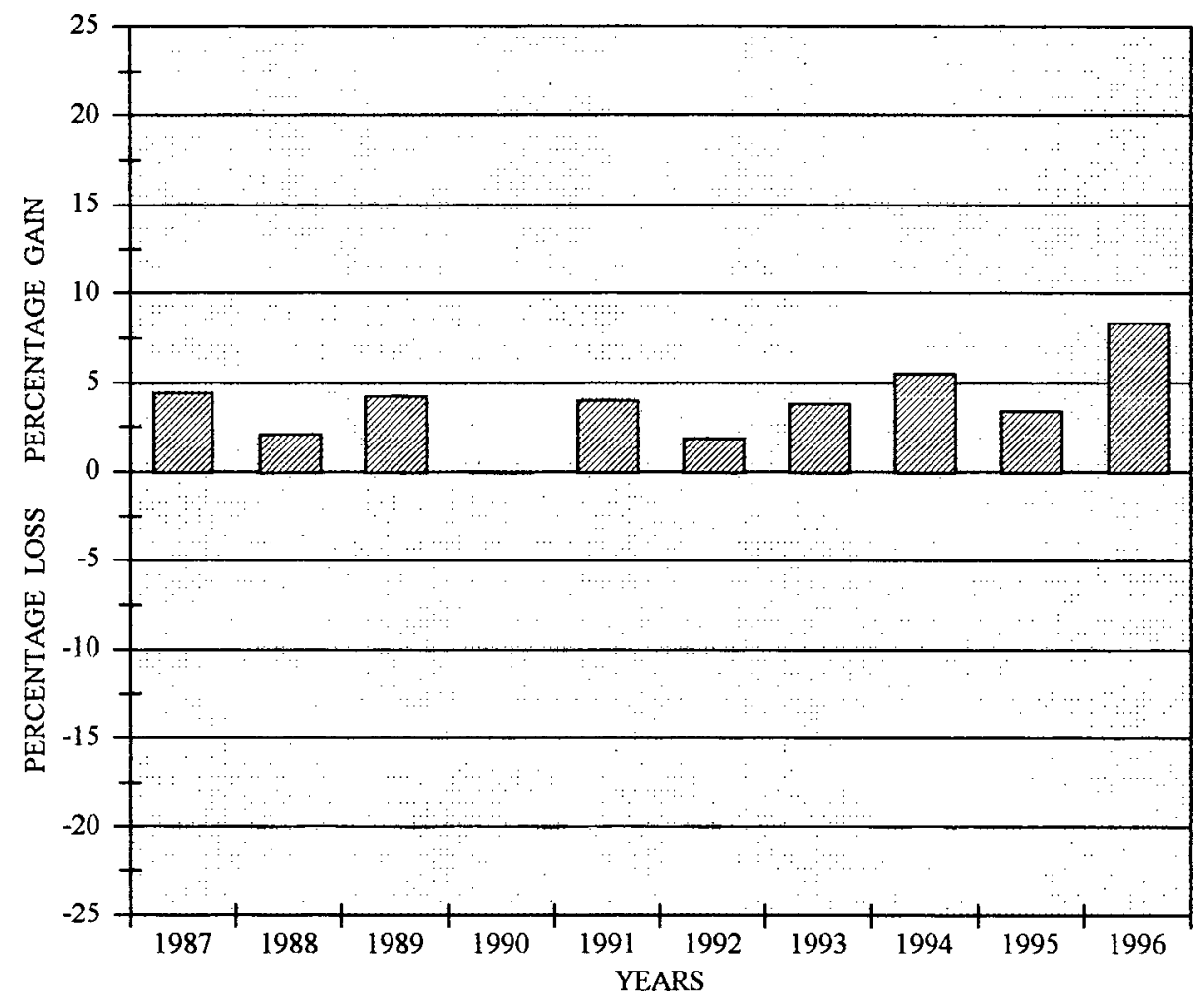

\begin{tabular}{|l|c|c|c|c|c|c|c|c|c|c|}
\hline Year & 1987 & 1988 & 1989 & 1990 & 1991 & 1992 & 1993 & 1994 & 1995 & 1996 \\
\hline AGR & 4.4 & 2.1 & 4.2 & 0 & 4 & 1.9 & 3.8 & 5.5 & 3.4 & 8.3 \\
\hline
\end{tabular}

Figure 7. Annual growth rates, SDA Church, Areeparambu. 
If the remedies suggested below (see pages 80-81) are implemented, the Areeparambu Church can grow. Figure 8 shows a faith projection suggesting that the church could reach 100 members by 2002 .

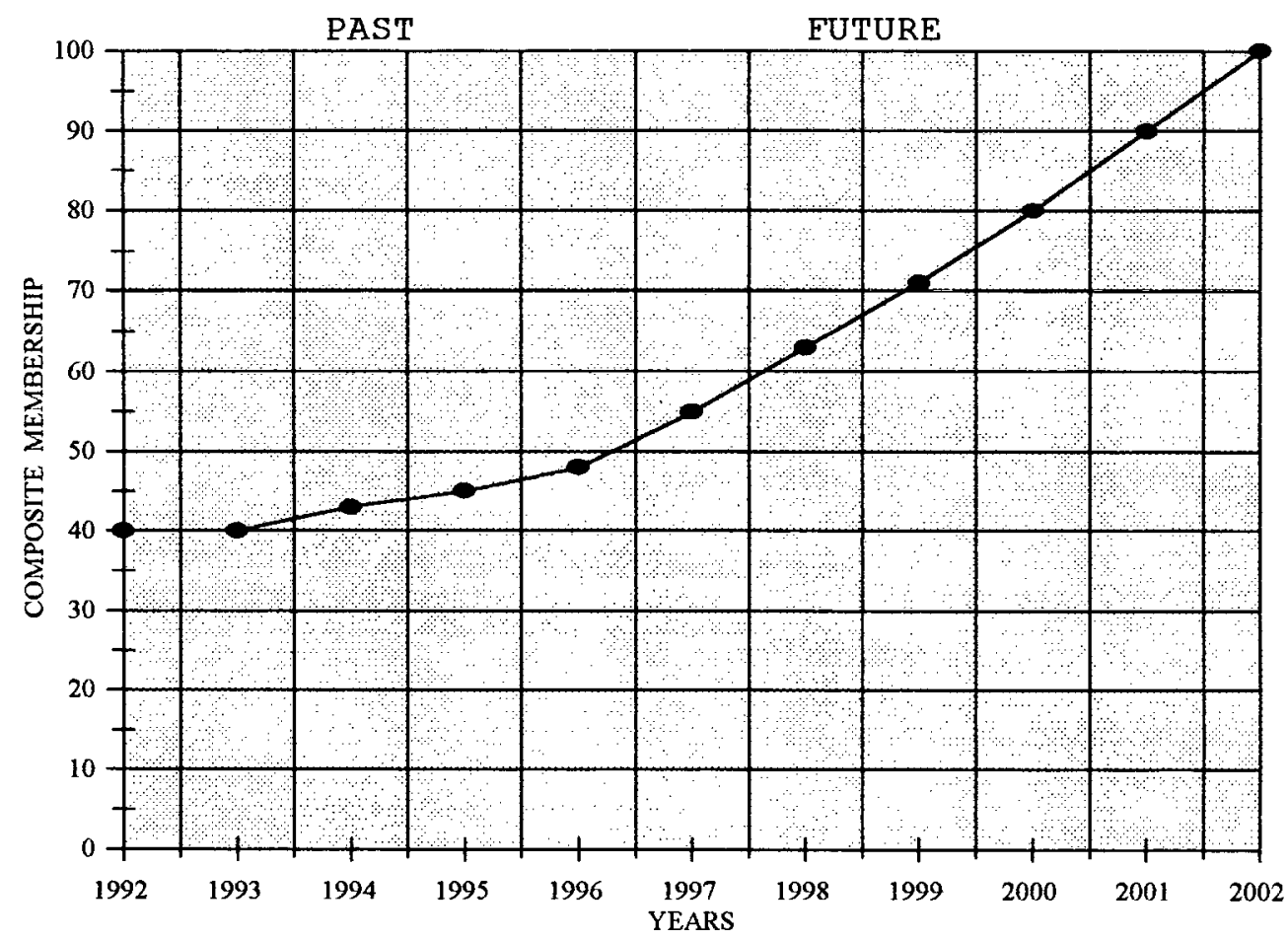

\begin{tabular}{|l|c|}
\hline YEARS & 1992 \\
\hline MEMBERS & 41 \\
\hline
\end{tabular}

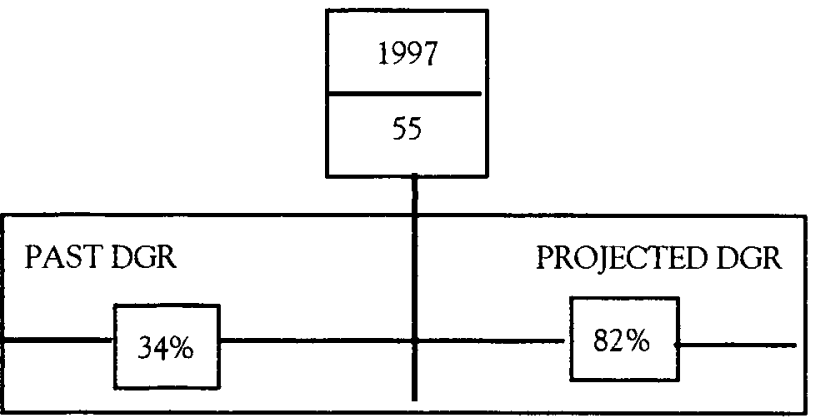

\begin{tabular}{||l|c|c|c|c|c|}
\hline Years & 1998 & 1999 & 2000 & 2001 & 2002 \\
\hline Membership & 63 & 71 & 80 & 90 & 100 \\
\hline
\end{tabular}

Figure 8. Faith projection, SDA Church, Areeparambu. 
This church is not a growing church. The members are not actively taking part in outreach programs. Another factor which has affected the growth of the church has been the constant change of the pastors. From 1987 to 1996 four pastors led this church. From 1987 to 1989 there was no growth; not even members' children were baptized during this time. Some of the active members left the church because of some misunderstandings with other members. The church failed in the timely ministry of reconciliation.

From 1994 to 1996 there was a slight growth because the pastor was able to encourage the members to do outreach work. In 1994, during my visit to this church, I was able to motivate them to lay evangelism and a 1,000-home visiting program was organized by the elders of the church. It was my privilege to inaugurate the program and the members were able to reach 1,000 homes with the gospel message. But there was a failure in follow-up work, for those members were inexperienced in witnessing and had no training. In 1995 there was a series of revival meetings which helped the members to regain vitality in their spiritual journey. At that time the church decided to conduct a Vacation Bible School every year.

In ten years there were only 18 baptisms; among these were children of members. At the same time, 15 members were dropped. Thus, the church did not grow.

The following were the hindrances for the growth of the church:

1. The majority of the members were not interested in outreach programs.

2. Most of the members are ladies, who in this area generally do not go out to witness.

3. There was a lack of vision in the pastors.

4. There was insufficient lay training. 
5. The church lacked unity.

\section{Proposed Growth Strategies}

Something should be done to revive the Areeparambu Church from today's condition. I would suggest the following strategies:

\section{Motivation of the Members}

The members should be instructed regarding their calling and responsibility as light bearers and motivated to become involved in evangelism and church growth activities.

\section{Lay Training}

One-week lay training programs should be conducted in this church.

\section{Visiting Inactive Members}

The members feel that home visitation is the duty of the pastor. This concept should be changed. Both the members and the pastors should jointly take part in visiting homes. A special emphasis should be given to reclaiming inactive members.

\section{$\underline{\text { Revival Meetings }}$}

Revival meetings should be conducted every year to strengthen the members. These revival meetings help the inactive members to become active and the backsliders to come back to the fold.

\section{Church Unity}

The members need to be educated regarding church unity so that the concept of 
oneness will be in them. This will help to avoid quarrels among the believers.

\section{Kurichy Church}

History of the Church

In 1946 A. P. John, a Church of South India member at Kurichy, received a pamphlet entitled "Which Day Do You Keep and Why?" published by Pastor S. N. David. As a result of studying it, he understood the importance of Sabbath keeping and kept the Sabbath alone at home for one year. At this time he faced opposition from his parents and brothers. In 1948 he found out that there were Sabbath keepers at Mooledom and went there to observe the Sabbath. In the same year he was baptized by Pastor Joshua at Chengalam.

John wanted to share this truth with his people. Thus in 1950 A. F. Jesson, then section president, conducted a series of evangelistic meetings at Kurichy. As a result of these meetings John's parents and relatives joined the church. In 1951, S. S. Lawrence was appointed as church pastor. After him K. J. Isaac became pastor in 1960. In 1968, while M. U. Thomas was pastoring this church, the church building was constructed. In 1970 John conducted lay efforts and brought other family members to the church.

\section{Growth Patterns}

Table 5 shows the membership statistics for the Kurichy Church from 1987 through 1997. The rate of increase has been slow. In the ten years, there were 21 baptisms, but 8 were members' children. 
TABLE 5

MEMBERSHIP STATISTICS, 1987 - 1997

KURICHY CHURCH

\begin{tabular}{|c|c|c|c|c|c|c|c|c|c|c|c|}
\hline & $\underline{1987}$ & $\underline{1988}$ & 1989 & $\underline{1990}$ & $\underline{1991}$ & $\underline{1992}$ & $\underline{1993}$ & $\underline{1994}$ & $\underline{1995}$ & $\underline{1996}$ & $\underline{1997}$ \\
\hline Membership & 40 & 39 & 37 & 37 & 39 & 36 & 34 & 38 & 41 & 45 & 50 \\
\hline Sabbath Sch Attn & 25 & 28 & 30 & 32 & 32 & 35 & 36 & 38 & 38 & 40 & 45 \\
\hline Church Attendance & 45 & 47 & 48 & 50 & 50 & 52 & 53 & 55 & 58 & 60 & 65 \\
\hline Baptisms & 1 & 0 & 2 & 1 & 1 & 0 & 2 & 4 & 4 & 3 & 5 \\
\hline Baptism-Non-SDA & 1 & 0 & 2 & 0 & 1 & 0 & 0 & 2 & 2 & 2 & $3^{\prime}$ \\
\hline Bapt-SDA Childrn & 0 & 0 & 0 & 1 & 0 & 0 & 2 & 2 & 2 & 1 & 2 \\
\hline Transfers In & 0 & 0 & 0 & 2 & 0 & 0 & 2 & 2 & 0 & 0 & 0 \\
\hline Transfers Out & 2 & 0 & 0 & 0 & 2 & 0 & 0 & 0 & 0 & 0 & 0 \\
\hline Deaths & 0 & 0 & 0 & 1 & 0 & 0 & 0 & 1 & 0 & 1 & 1 \\
\hline Members Dropped & 0 & 2 & 2 & 0 & 2 & 2 & 0 & 2 & 0 & 2 & 2 \\
\hline Compos Members & 36 & 38 & 38 & 39 & 40 & 41 & 41 & 43 & 45 & 48 & 55 \\
\hline
\end{tabular}


Figure 9 shows the rate of growth of the composite membership. The composite membership of the Kurichy Church in 1987 was 40. By 1990 it was only 44. In 1993 there was no increase at all. In 1995 only one member was added, but in 1996 and 1997 there was growth as a result of the combined ministry of the pastor and a few members.

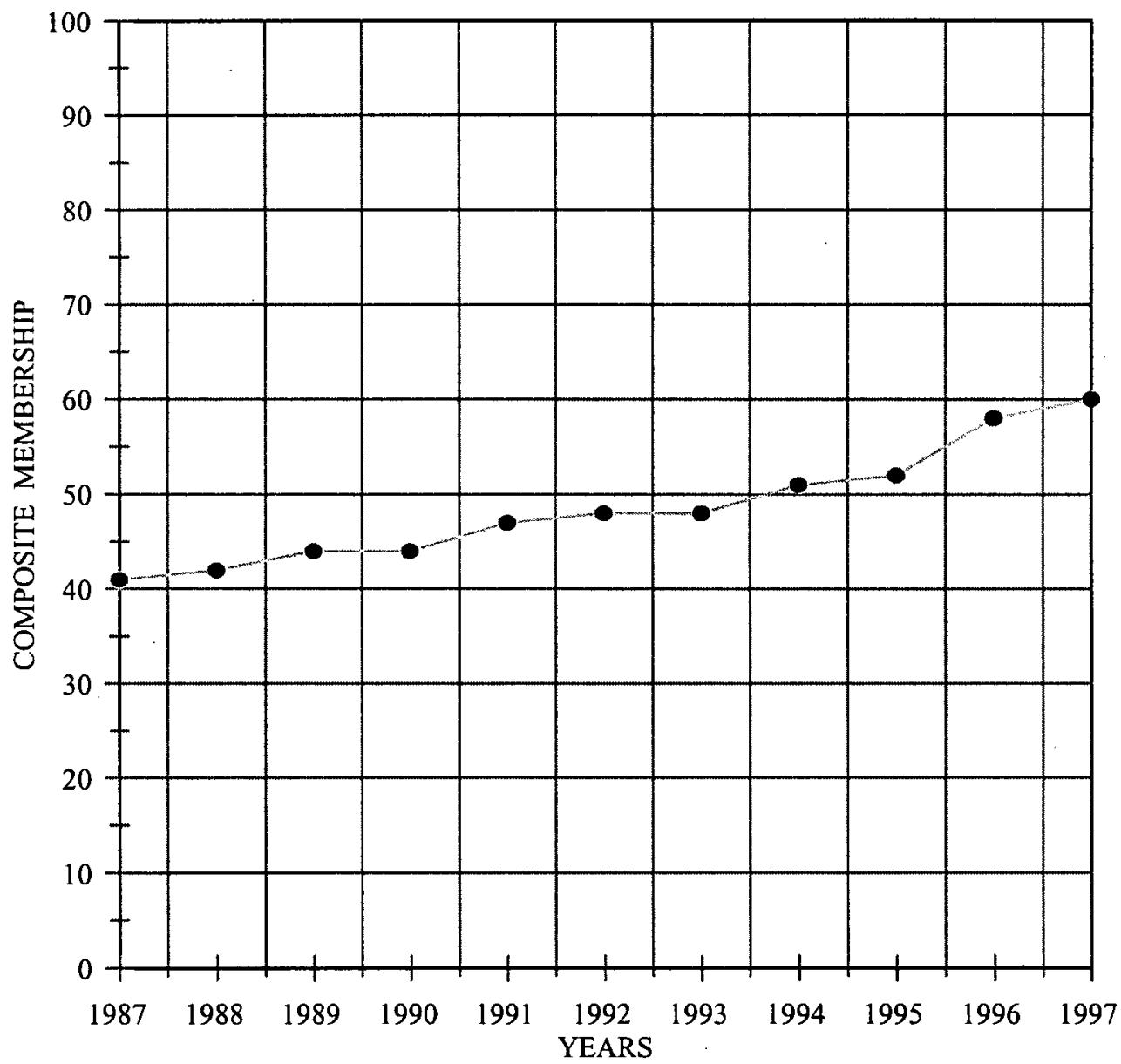

\begin{tabular}{|l|c|c|c|c|c|c|c|c|c|c|c|}
\hline Years & 1987 & 1988 & 1989 & 1990 & 1991 & 1992 & 1993 & 1994 & 1995 & 1996 & 1997 \\
\hline Members & 41 & 42 & 44 & 44 & 47 & 48 & 48 & 51 & 52 & 58 & 60 \\
\hline
\end{tabular}

Figure 9. Membership growth rate of the Kurichy Church. 
Figure 10 shows the active members of Kurichy Church. There is a slight increase from 1987 to 1997, but in 1993 there was no increase at all. From 1994 onwards membership increase is seen. In 1987 the active membership was 50; it grew to 75 in 1997. This shows a DGR of 50 percent.

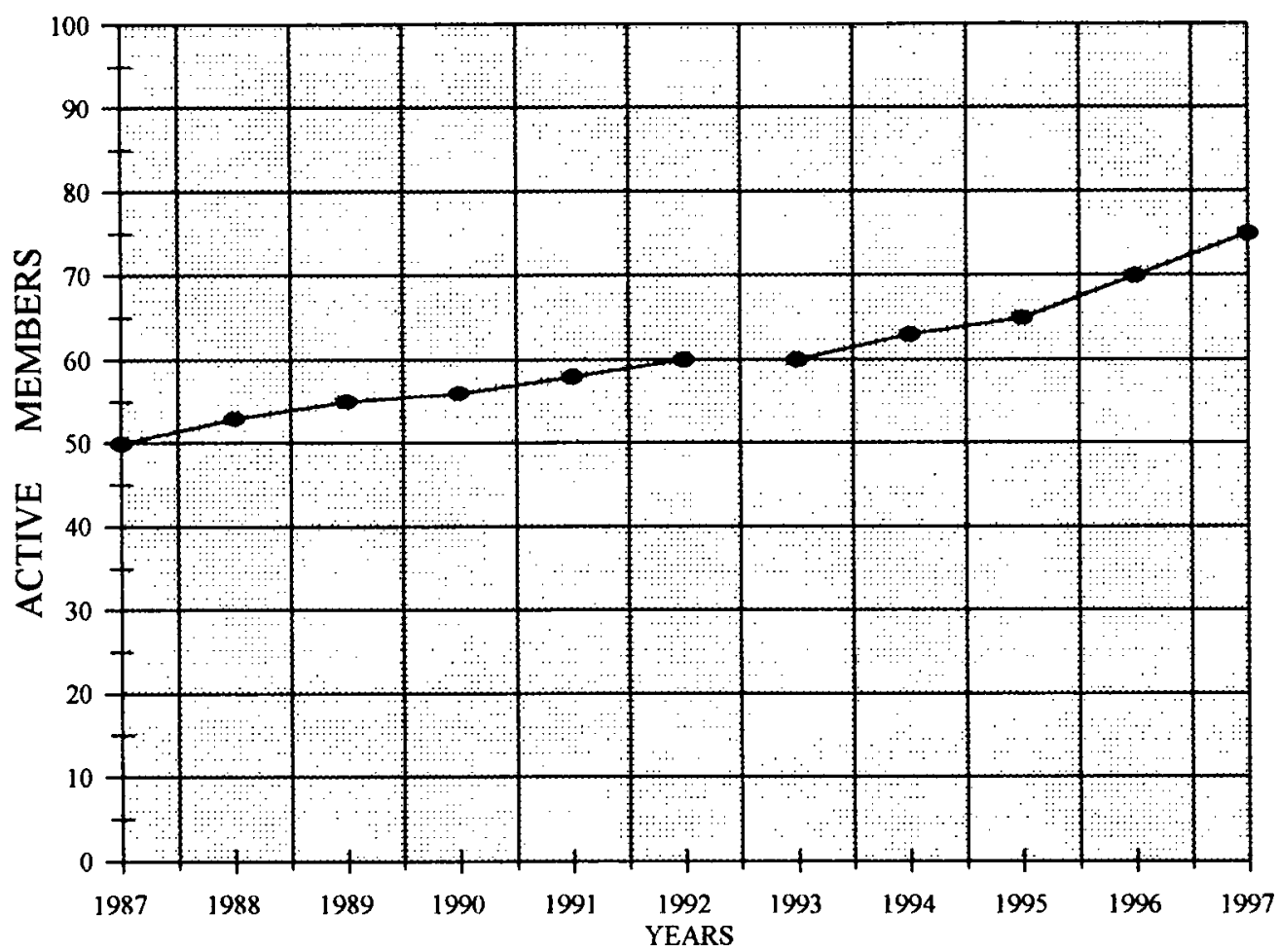

\begin{tabular}{|l|c|c|c|c|c|c|c|c|c|c|c|}
\hline Year & 1987 & 1988 & 1989 & 1990 & 1991 & 1992 & 1993 & 1994 & 1995 & 1996 & 1997 \\
\hline Members & 50 & 53 & 55 & 56 & 58 & 60 & 60 & 63 & 65 & 70 & 75 \\
\hline
\end{tabular}

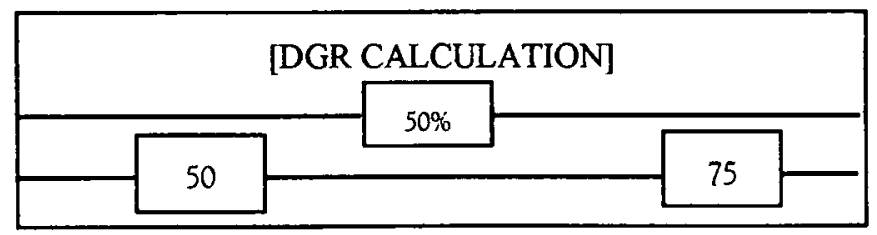

Figure 10. Decadal growth rate at Kurichy Church, $1987-1997$. 
Figure 11 shows the annual growth rate of the Kurichy Church. The lowest AGR was 0 in 1992, while the highest was 7.7 in 1995.

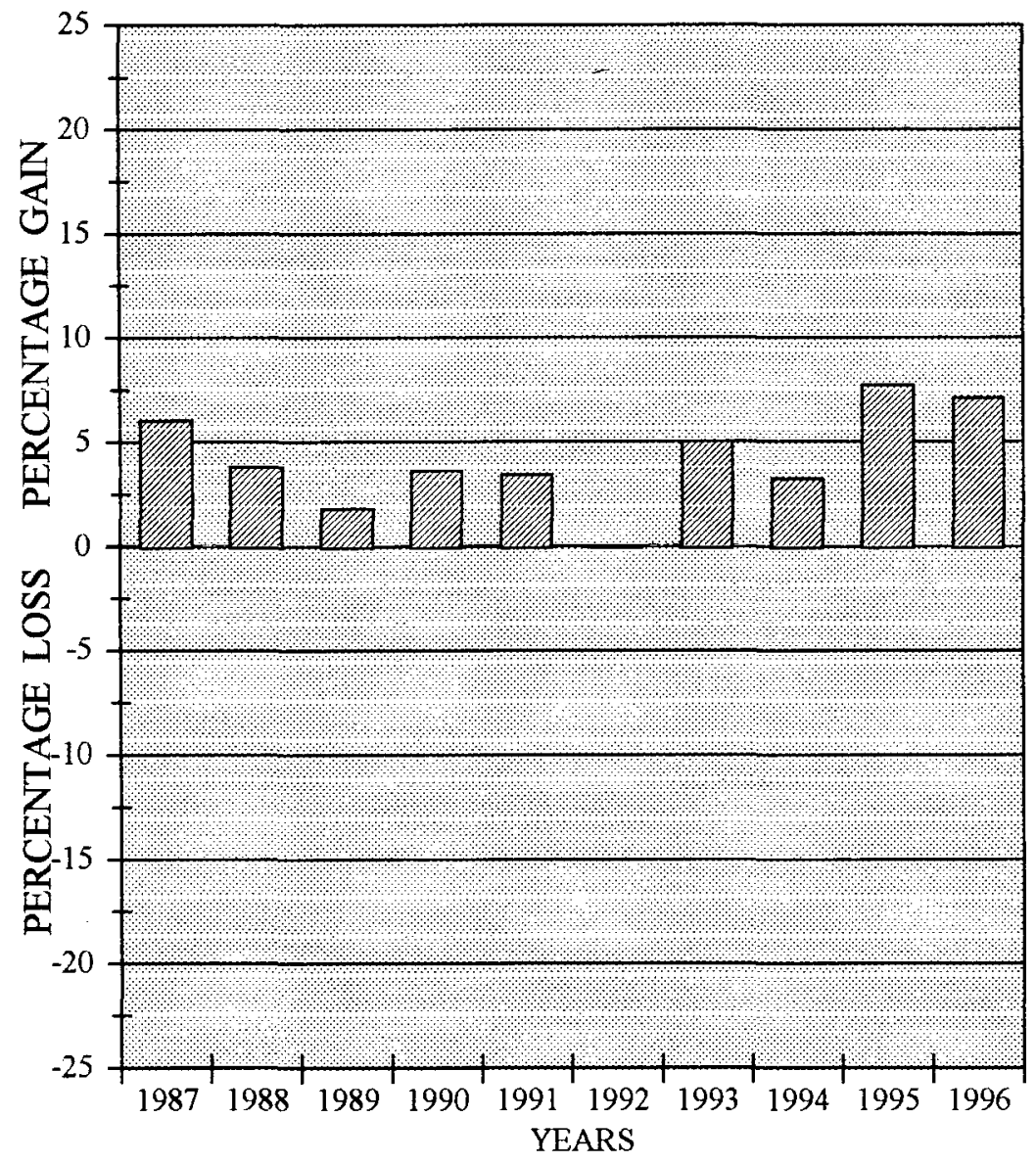

\begin{tabular}{|l|c|c|c|c|c|c|c|c|c|c|}
\hline Years & 1987 & 1988 & 1989 & 1990 & 1991 & 1992 & 1993 & 1994 & 1995 & 1996 \\
\hline AGR & 6 & 3.8 & 1.8 & 3.6 & 3.4 & 0 & 5 & 3.2 & 7.7 & 7.1 \\
\hline
\end{tabular}

Figure 11. Annual growth rate of the Kurichy Church, $1987-1997$. 
Figure 12 shows the faith projection for the Kurichy Church. If the suggested strategies are implemented, the membership could reach 100 by 2002 .

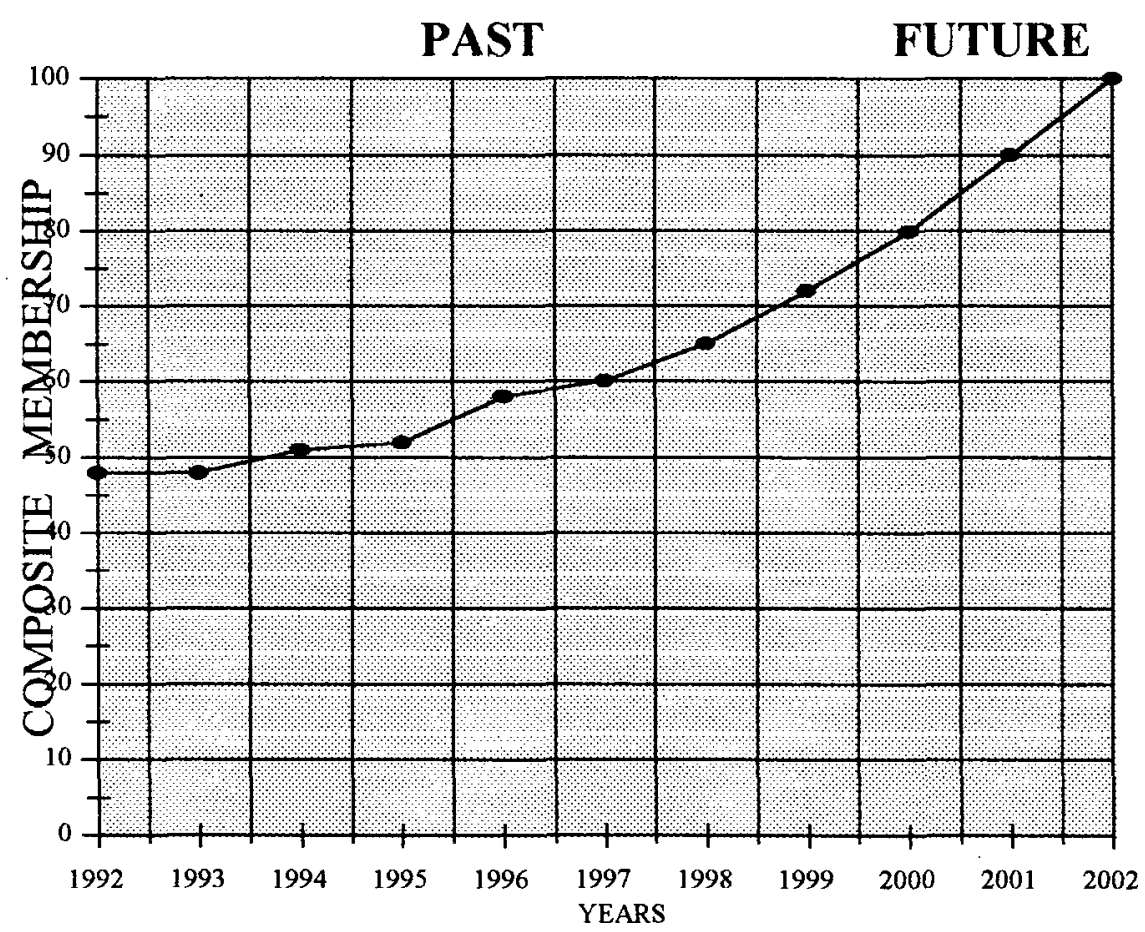

Year 1992

Members 48

1997

60

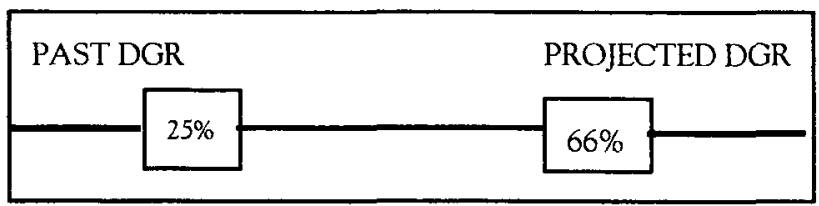

\begin{tabular}{||l|c|c|c|c|c|}
\hline \hline Years & 1998 & 1999 & 2000 & 2001 & 2002 \\
\hline Membership & 65 & 72 & 80 & 90 & 100 \\
\hline
\end{tabular}

Figure 12. Faith projections, Kurichy Church. 
During these years, 14 members were dropped and 4 died. The statistics show that Kurichy is not a growing church. There are many reasons why this church is not growing. Changing pastors often has contributed. In ten years pastors were changed four times. Another factor which affected the growth of this church is that the members were not involved in outreach programs. They feel that evangelism was the pastor's work and they need not bother about it. Many of them appear not to have a concern or burden for the lost.

A majority of the members are poor and work for daily wages. They do not witness for Christ in their working places. They feel that they are from the lower class and what they say will not be accepted by the high-class people. They also feel that church worship is monotonous and there is a lack of spirituality in the church. There is lack of visitation, as well as a lack of love and fellowship in the church. Members feel that the programs of the church do not meet their needs.

\section{Strategies for Growth}

\section{$\underline{\text { Inspiring Worship Services }}$}

A new worship format should be introduced to meet the needs of the local people. People should feel that they are an integral part of the worship service.

\section{$\underline{\text { Revival Meetings }}$}

When Pentecostal church members visit the Adventist Church, they say there is no revival in the Adventist Church. Already plans have been made to conduct revival meetings every year to refresh the spiritual atmosphere in the church. 


\section{Outreach Programs}

The members should be encouraged to witness. The church as a whole should take part in the outreach program. Every member can do something for Jesus. There is no one without any talents. If one cannot preach or give Bible studies, at least he or she can carry a tract and hand it to someone as a kind of witnessing. Plans have been laid to motivate and train the members for active participation in outreach programs.

\section{Small-Group Prayer Ministry}

As the members of this church do not live near the church, it would be easy to start several cell groups. Many are interested in this small-group prayer ministry and it has already started in a few homes. This will help the church grow. 


\section{CHAPTER V}

\section{STRATEGIES}

This chapter deals with workable strategies for the churches in the Kottayam district. A ten-day lay training program will help to prepare the members to carry out the church responsibilities as well as do outreach more effectively. The necessity of having a new worship format appropriate to the local situation is emphasized. Introducing the six stages of prayer will result in church growth. Cell-group ministry will be used as a strategy. Conducting a two-day church growth seminar will help to set goals for church growth. Health seminars will be an effective strategy to get openings for the gospel among the Hindus. These strategies will be implemented in the local churches in the first stage, at the district level at the second stage, and at last section wide.

\section{Lay Training}

For the benefit of the Seventh-day Adventist churches in the Kottayam District, I would like to conduct a lay training program. The objective is to train the laity to take care of the activities of the church and also of the outreach programs. Pastors cannot do all the work, but when unpaid common men and women teach the Bible, lead in prayer, tell what God has done for them, and exhort the members, the church will grow. The following sections describe different aspects of the proposed training session. 


\section{Curriculum}

The first thing in the lay training program is to set a curriculum. It shows what courses will be taught. This curriculum includes:

1. Training for elders, deacons, and deaconesses-how to conduct mid-week prayer meetings, vespers, divine services, and fasting and prayer sessions.

2. Biblical studies to enhance the lay members' understanding of the Bible and the fundamental doctrines of the church. Answers to objections: The issues regarding doctrinal questions Adventist church members are asked by persons of other denominations.

3. Evangelistic methods, with special emphasis on personal evangelism, cottage meetings, group Bible studies, and lifestyle and friendship evangelism.

4. Classes on health principles and first-aid.

5. Soul-winning strategies: prayer ministry, cell-group ministry, and public evangelism.

6. Prayer and meditation.

Classes will be divided as follows:

1. Bible Doctrines (BD) - 25 hours

Creation and evolution, archeology and the Bible, the Trinity, the problem of sin, the plan of salvation, the rapture, the state of the dead, spiritualism, the Sabbath and the development of Sunday worship, stewardship, the unchangeable law of God, the Christian home, baptism, the Lord's Supper, the three angels' message, the sanctuary, the 2,300-day prophecy, the church and its mission, the judgment, heaven and hell, the millennium, everlasting fire, last-day events, spiritual gifts, and the baptism of the Holy 
Spirit.

2. Health and First-Aid (H\&F) - 4 hours

Natural remedies, hydrotherapy, temperance, first aid.

3. Evangelistic Methods (Ev) - 4 hours

Personal evangelism, friendship evangelism, open air meetings, cottage meetings.

4. Strategies (St) - 3 hours

Cell groups, prayer ministry, Bible study methods.

5. Prayer and meditation

- 4 hours

TOTAL

40 hours (See Table 6.)

General Program

The duration of the training will be ten days, including two Sabbaths. There will be classes for eight days, with a total of 40 hours ( 5 hours per day). Another 40 hours will be for practicum. The training will start on a Thursday and close on the following Sabbath. During the first Sabbath, a fasting and prayer session will be conducted from 9:00 a.m. to 5:00 p.m. In the evening, from 7:00 to 9:30, a series of revival meetings will begin. The program will be closed with a consecration service on the following Sabbath. Certificates will be awarded at the end of this training program.

The instructors will be Union and Conference personnel. The Conference leaders as well as the department directors will supervise it. Most of the lay members are interested in attending, for it will be like a camp experience to them. This could be one way of organizing the lay training. If it is successful, another program can be organized the following year for few weekends or during holidays. 


\section{Daily Program}

The classes will be from 7:30 a.m. to 1:00 p.m. From 3:00 to 6:00 p.m. there will be a witnessing or outreach program for eight days, which will give 24 hours of practical work. In the first two days, from 7:00 to 9:30 p.m. special prayer sessions will be conducted. There will be a series of revival meetings daily from Saturday to Friday from 7:00 to 9:30 p.m. These will count for another 20 hours of practical work.

\section{Selection of Trainees}

This training program will be conducted on different levels. At first, it will be conducted for the three churches of Kottayam. The delegates from these three churches will gather at the Vadavathoor school campus. It is a convenient place where the members of three churches can come and stay, since free accommodations are available. Moreover, this is the place where all types of seminars are conducted by the conference as well as the churches of the Kottayam district. The local churches will select the trainees. This will be a church-oriented program and there will be no funds given by the Section office. All the expenses will be met by the local churches. This training program will be for 50 people; Kottayam church will have 20 delegates, Kurichy and Areeparambu, 15 each.

The second level of training will be conducted in the major churches of the conference. It will be conducted in the local churches and the trainees will be chosen according to the membership of the church. In the major churches the number of trainees will be between 25 and 50 . 
TABLE 6

\section{A PROPOSED PROGRAM SCHEDULE}

\begin{tabular}{|c|c|c|c|c|c|c|c|}
\hline Day & $\begin{array}{l}7: 30 \\
8: 30\end{array}$ & $\begin{array}{l}8: 30 \\
9: 30\end{array}$ & $\begin{array}{l}9: 45 \\
10: 45\end{array}$ & $\begin{array}{l}10: 45 \\
11: 45\end{array}$ & $\begin{array}{l}12: 00 \\
1: 00\end{array}$ & $3: 00-6: 00$ & $\begin{array}{l}\text { 7:00-9:30 } \\
\text { p.m. }\end{array}$ \\
\hline Thu & $\mathrm{BD}$ & $\mathrm{BD}$ & $\mathrm{EV}$ & $H \& F$ & $\mathrm{BD}$ & Witnessing & $\begin{array}{l}\text { Prayer } \\
\text { Session }\end{array}$ \\
\hline Fri & $\mathrm{BD}$ & $\mathrm{BD}$ & EV & $H \& F$ & $\mathrm{BD}$ & Witnessing & $\begin{array}{l}\text { Prayer } \\
\text { Session }\end{array}$ \\
\hline Sabbath & & Sabbath & chool \& I & vine Serv & & $\begin{array}{l}\text { Fasting \& } \\
\text { Prayer }\end{array}$ & $\begin{array}{l}\text { Revival } \\
\text { Meetings }\end{array}$ \\
\hline Sun & $\mathrm{BD}$ & $\mathrm{BD}$ & EV & $H \& F$ & $\mathrm{BD}$ & Witnessing & $\begin{array}{l}\text { Revival } \\
\text { Meetings }\end{array}$ \\
\hline Mon & $\mathrm{BD}$ & $\mathrm{BD}$ & St & $H \& F$ & $\mathrm{BD}$ & Witnessing & $\begin{array}{l}\text { Revival } \\
\text { Meetings }\end{array}$ \\
\hline Tue & $\mathrm{BD}$ & $\mathrm{BD}$ & St & $\mathrm{BD}$ & $\mathrm{BD}$ & Witnessing & $\begin{array}{l}\text { Revival } \\
\text { Meetings }\end{array}$ \\
\hline Wed & $\mathrm{BD}$ & $\mathrm{BD}$ & St & EV & $\mathrm{BD}$ & Witnessing & $\begin{array}{l}\text { Revival } \\
\text { Meetings }\end{array}$ \\
\hline Thu & $\mathrm{BD}$ & $\mathrm{BD}$ & $P \& M$ & P\&M & $\mathrm{BD}$ & Witnessing & $\begin{array}{l}\text { Revival } \\
\text { Meetings }\end{array}$ \\
\hline Fri & $\mathrm{BD}$ & $\mathrm{BD}$ & $P \& M$ & $P \& M$ & $\mathrm{BD}$ & Witnessing & $\begin{array}{l}\text { Revival } \\
\text { Meetings }\end{array}$ \\
\hline Sabbath & \multicolumn{5}{|c|}{ Sabbath School \& Divine Service } & Testimonies & $\begin{array}{l}\text { Consecration } \\
\text { Service }\end{array}$ \\
\hline
\end{tabular}


The third level of training will take place where three to four nearby churches can come together. At this level the local churches will select the trainees and meet the expenses.

The next level of training will cover all the churches in a pastoral district. The churches will select the trainees and all expenses will be met by them.

The last level is a conference-wide training. The selection of the trainees and the budget provision will be made by the conference.

\section{Resources}

All the trainees should have the desire to study the Scriptures. Also, they should be interested in the soul-winning ministry. The instructors' soul-winning experiences and illustrations will encourage others to do a tremendous work for the growth of the church.

Printed notes will be provided to help the trainees in their further studies and the evaluation of their performances. The place should be calm and quiet so that they can spend enough time in prayer and meditation and a spiritual atmosphere can be maintained.

\section{Evaluation}

After the training, the trainees will be given opportunity to conduct programs in the church under the supervision of the pastor. They will then be sent out for outreach programs along with assigned leaders. There should be an evaluation team including pastors and lay members. They should evaluate the performance based on the principles taught in the training. Also, they must give a report with suggestions and recommendations which will help the trainees in their further work. 


\section{Worship Renewal}

Many of the members of the Adventist Church in Kerala feel that the worship services are quite boring. Many do not attend worship services due to this reason. I would like to make the worship culturally relevant and attendance a way of life. Growing churches have worship services that inspire people. The members of the church should be taught the meaning of worship. Worship must be focused on God, praising God or adoring God. Worship is a key factor in church growth. The worship services should be Christ centered and should give glory to God. They should edify the worshippers and transform them. They should appeal to visitors also. True worship is celebration, fellowship, and thanksgiving for all the mercies of God.

\section{A New Worship Format}

The worship format used now is not appropriate to the local situation. The younger generation needs a new style. The order of service should be simplified. A sermon is not compulsory every week; instead, personal testimonies can be given. More time should be given to adoration songs. After that, a fifteen-minute period of witnessing to personal experience of the mercies of God would be appreciated. Then the worshipers will feel that they are an integral part of the worship. I would like to evaluate the effectiveness of response-oriented worship that meets the needs of the worshipers.

\section{Worship Leader}

There should be worship leaders in every church to co-ordinate the services of the church. A good worship leader prepares the congregation for worship. I would like to train worship leaders in all the churches because worship services are not well planned 
due to the absence of worship leaders. The worship leader should have a prayerful preparation in arranging worship services. He prays before the service begins. He should allow sufficient time for worship events. There should not be a hurried service. $\mathrm{He}$ should encourage participation of the congregation rather than their being spectators.

\section{Music}

Music is a major vehicle for celebration and communication. The young people listen to music more than to their parents. Music can carry Christian messages. There are many songs from the Psalms written in Malayalam, the local language. They are very powerful because they are the music from the heart. Some people do not like to sit in church for a long time, but they are attracted to music. The Scripture says, "Sing unto the Lord a new song; sing unto the Lord, all the earth" (Ps 96:1). Many churches use old songs that many do not like today. I would like to encourage the members to compose new songs. Except for a few songs translated from the English church hymnal, all other songs should be Indian. With the possible exception of a few churches, all churches should use Indian instruments only.

\section{Sermons}

The pastor should find out the needs of the people. The sermons should meet the needs and heal the hurts of the people. Preaching should be clear, relevant, and applicable, so that it can change the lives. The truth should be presented in a simple way by stories that can hold the attention of the audience. The pastor should adapt his style to the congregation and preach from the Word of God. He should provide sermon outlines with texts. It helps the people to take notes, to remember the message, and to review it. 
It also saves time.

\section{Announcements}

In television programming everything is fast paced and there are no gaps.

Likewise, wasting time between different aspects of the worship service should be avoided. Where there is a hymn board, hymns should not be announced again. Where announcement sheets are not available, blackboards can be used; repetition and delay must be avoided.

\section{Prayer Ministry}

The key for church growth is prayer. A praying church always grows. Members should pray for the leaders of the nation and the church. They should pray daily, because Satan is happy with nominal Christians. The power of God is unlimited; if we ask little we receive little. As part of an effective prayer life consider prayer chains. If there is a monthly prayer calendar maintained, it helps the church to identify a different family to pray for each day. A proper prayer journal provides records of God's answered prayers, and stimulates and encourages people. Deeper intimacy with God is possible through a prayer ministry. Each church must develop a strong prayer ministry. It is the spiritual thermometer of the church.

Fasting and prayer should be introduced in each church at least once a month. Prayer requests should be collected and time should be spent in prayer. At prayer time, the pastor, the elders, and the deacons should lay hands on people and pray, because according to the Indian culture, the touch of the pastor during prayer is important. Regular fasting and prayer will result in power to help the church grow. 
There should be a prayer focus. Prayer seminars should be conducted in each church. There must be prayer teams in each congregation. Intercessory prayer groups should be recruited in all churches. Schedule all-night prayer meetings every month.

\section{Cell Groups}

A most important factor in growing churches is to have continuous multiplication of cell groups. As the basic building blocks of the church, the basic needs of the members of the church are met by the cell groups. ${ }^{1}$

A cell group will include a cell leader, an intern who will be with the leader always, and the members. In about six months the cells may multiply. Five to seven people form the cell group. Cell groups form a congregation because "a congregation is an extension of cell groups." ${ }^{, 2}$ In about six to nine months the membership of the cell group will grow from seven to fifteen, then it can be divided into two cells. By this time the intern will become the cell leader. ${ }^{3}$

In all cell groups communication goes on at many levels, spiritual growth is achieved, and leadership is developed. The use of triad will help to have maximum sharing in minimum time. The use of role playing and the use of feedback helps the cellgroup interaction. ${ }^{4}$ There should be submission to the Word of God, unconditional acceptance of each other, absolute forgiveness for each other, genuine support, and total

\footnotetext{
'Neighbour, 13.

2Ibid., 17 .

${ }^{3}$ Ibid., 45.

${ }^{4}$ Ibid., 152-153.
} 
confidentiality. "Bear one another's burdens and thus fulfill the law of Christ" (Gal 6:2).

The following is a suggested format of cell-group meeting.

Begin with refreshments.

Sit in a circle.

Introduction.

Use an "ice breaker."

Share and praise time.

Present the discussion topic.

Facilitate the discussion.

Share the Vision.

Close in group prayer. ${ }^{2}$

The sharing questions and the ice breakers help the people get in touch with each other. ${ }^{3}$ There should be singing of familiar songs, prayer, and Scripture reading. A typed song sheet will help the members, and more so, the visitors. Preaching and talking should be avoided between the songs. ${ }^{4}$

The leader should choose an appropriate topic for discussion. The topic should be one that will encourage, stimulate, or challenge-it should be a topic which meets felt needs. The cell leader, as a facilitator, guides the group in discovering and applying insights of their own. He should provide an experience, get feedback from the group, summarize the group's conclusion, and probe for principles retained by group members. He can ask, "What will you carry away from this experience? What is the main point?
${ }^{1}$ Ibid., 158-160.
${ }^{2}$ Ibid., 169-170.
${ }^{3}$ Ibid., 170-171.
${ }^{4}$ Ibid., 171-172. 
What is God saying to you through this Scripture?"'

\section{How to Start Cell Groups}

1. Prayerfully select five people to form the first cell. Do not take people who are always busy. Look for people with some kind of economic independence to use their houses, resources, and time in ministry.

2. Prepare for the first meeting. The first meeting should not be in the pastor's house. It must be in one of the lay member's houses. Instruct the host as to what to do and what not to do. Tell him not to prepare meals and not to decorate the house. Simple refreshments are permitted. The meeting will be held once a week for one and a half hours, at a time convenient for all.

3. Actual meeting. The pastor should be there half an hour before the scheduled time to finish all preparations with the host. He can take an apprentice to help him. The meeting will have the following parts.

a. Sit in a circle. Do not allow people to sit back. After the refreshments, start with a welcome. From the first meeting onwards, make the rules clear. Example: (1) Keep our sharing confidential. (2) Meet regularly once a week.

(3) Do not criticize anyone or discuss politics here. (4) Close with prayer. (5) Be available to each other in time of need. Remind people of the rules in each meeting. Emphasize again and again that sharing must be confidential.

b. Ice-breaker. Ask questions for each person to answer such as, Where did

${ }^{1}$ Ibid., 172-175. 
you live between the ages of seven and twelve and how many brothers and sisters do you have? Who was the person you felt closest to? When did God become real to you?

c. Praise time: 15 minutes. Use praise songs known to everyone.

d. Presentation by the leader. Emphasize that accountability and responsibility are important to grow spiritually.

e. Prayer time: Divide the groups into triads to pray. Have brief prayer for special needs.

f. Close the session with prayer.

The groups spend time in prayer, Bible study, and sharing their burdens with each other. On the tenth night, the meeting can be a half-night or all-night prayer meeting. It can begin with a fellowship meal.

\section{How to Continue Cell Groups}

Run the group for seven to twelve weeks, involving each of the members as an apprentice. The apprentice should be given a part in the meeting and told about this participation one week ahead of time. In each meeting some variation on the prayer focus should be included.

The pastor leads out only the first cycle. But he will prepare apprentices or interns as cell leaders. Every cell leader should have an intern from the day a cell group is launched. The cells should divide into two cells as soon as the members increase to more than twelve. When a cell is divided, the leader continues leading one cell while the apprentice becomes the leader of the other cell. Apprentices are immediately selected for 
the two new cells. As this process continues, the church grows.

\section{$\underline{\text { Health Seminars }}$}

There are some areas in Kerala where the non-Christians are prejudiced against Christians. There is a general feeling that the Christians are beef-eaters, pork-eaters, and drunkards. In such areas, the health message can be an opening to the gospel. When the people realize that the Adventists are health-caring people, and they are not like other Christians, that they do not smoke, drink, or eat pork, the church will be able to establish credibility in the society. Today, due to the increase of heart diseases, vegetarianism has a tremendous influence in society, especially among Hindus. Men and women are concerned about their health, and they will be more eager to hear about health than about the gospel. So a health seminar will be conducted in an unreached area. This will be a pilot program with the help of the personnel of the Ottapalam SDA hospital.

The duration of this seminar will be fifteen days. Each evening there will be a one-hour health lecture and an hour of discussion. The first day, there will be a temperance rally conducted by the students of the nearest SDA school, with slogans on placards on health principles and posters that demonstrate health principles. Visual aids will be used with the lectures.

The following is a suggested list of topics for lectures.

1. Natural remedies

2. Vegetarian cooking

3. Weight control

4. Stress management 
5. Exercise

6. Nutrition

7. Diabetes control

8. Prevention of heart diseases

9. Prevention of cancer

10. Hydrotherapy

11. Old-age problems

12. Temperance

13. Family health

14. Health in the Bible

15. God and healing.

Before the close of the seminar, all attendants should be invited to enroll in a health correspondence course. Interested persons should be located and visited. This program will give an opening to present the truth without prejudice.

A systematic follow-up should be done to visit homes and give Bible studies. This should continue for six months, and at the end of six months there will be a few ready for baptism. Baptize them, and with their help, conduct evangelistic meetings for a month. In these meetings, every evening have a half-hour lecture on health and then a one-hour lecture from the Bible. A five-day plan to stop smoking can be conducted.

The same type of health seminars can be conducted in different areas with the help of the Rotary Club, Lions Club, YMCA, YWCA, and other social organizations. Five-day plans can also be conducted along with the health seminars. This will help to enter new areas and reach receptive people, so that the gospel can be preached more 
effectively, and ultimately the church will grow.

\section{Church Growth Seminar}

The pastors and the elders of the church have not been trained in church growth and other related skills. In both urban and rural areas, the church lacks leaders. Lay leaders are the key element for the growth of the church in their own cultural settings. There is slow growth and lack of models in the church. So I would like to conduct a twoday church growth seminar in the three churches of Kottayam in A.D. 2000. This will be a church-oriented program, open to all members. It will be a church-supported program without any financial involvement from the section. Later, the same program can be conducted for larger groups.

\section{Focus}

The main focus is to motivate and empower the church through strategic church growth training. This seminar will help the church in vision building, leadership development, ministry skill enhancement, and long-term mentoring. It also will help the church in developing strategic thinking, mobilization, and in enhancing the effectiveness of the ministry. Moreover, it will help to set goals for church growth.

\section{Content}

The seminar will include teachings on the following topics:

1. Church growth principles

2. Bible study methods

3. Team building 
4. Community development

5. Prayer ministry

6. Cell-group ministry

7. Programs of the church.

There will be a gap of six months between the lay training and the church growth seminar so that evaluation will be possible and needed rectification can be done. So far this type of program has not been introduced in the Adventist church in Kerala and I hope this will help the church to grow. 


\section{CHAPTER VI}

\section{SUMMARY, CONCLUSION, AND RECOMMENDATIONS}

\section{$\underline{\text { Summary }}$}

\section{The Problem}

During the twenty-six years of my ministry, I have seen that the North Kerala Section has not been growing. In many churches, over 50 percent of the members on the church records do not attend church. They say the worship services are monotonous, quite boring, and do not meet the needs of the people. They also say that there is no revival in the church. The Pentecostals started their work after the Adventists, but the Pentecostals are the fastest growing churches in Kerala. While those churches are selfsupporting, the Adventist churches are not self-supporting, and also are stagnant. Insufficient training, lack of church unity, lack of motivation, lack of vision, lack of visitation, lack of lay mobilization, lack of prayer, and casteism in the church have hindered the growth of the church.

\section{Present Situation}

As part of my D.Min. studies, I learned about church growth principles, and I read about growing churches in the world and the factors that helped those churches grow.

When I went back to the field after my first year, I visited the Kottayam, Areeparambu, 
and Kurichy churches and saw the condition of those churches. When I shared my insights on growth strategies, the members were impressed. I emphasized prayer ministry, healing ministry, and cell-group ministry. The Kottayam Church conducts a prayer and healing ministry every Sabbath afternoon. They collect prayer requests from others and pray over them. I would like to introduce prayer chains in other churches very shortly.

I talked with the section leaders about conducting a church growth seminar, and I received a positive response. I also talked to them about the lay training program, and they said that they would make the necessary arrangements for a training program.

\section{Solutions}

From my church growth study, I found that the Bible presents God as a finding God as well as a searching God. He has a concern for the lost. Jesus was not interested in mere preaching, He was serious about a response. The very existence of the church is evangelism or fulfilling the gospel commission.

The Book of Acts records in detail the growth of the church. The early church had continual evangelistic activity. The persecution that started because of the preaching of Stephen resulted in Philip's evangelistic labor and Saul's conversion. The refugees from Jerusalem came to Antioch and preached Jesus to the Jews who lived there. Some of them even preached to the Gentiles who accepted the gospel in great numbers. After establishing new churches the apostle Paul returned to visit and strengthened them.

A pastor with vision will meet the needs of his people. He should visit all the members, especially the sick and the inactive members. He should organize visiting 
teams to assist him in visitation. To make the church a praying church, he should recruit intercessory prayer teams in the church. He should train the lay members for evangelism because when every member is trained and has taken part in evangelism, the church grows. He should mobilize the laity for outreach activities.

I found the following strategies appropriate to the situation. A ten-day lay training will help the laity to take care of the activities of the church as well as the outreach programs. Worship leaders should be appointed in every church for wellplanned worship services. Each church should develop a strong prayer ministry because it is the spiritual thermometer of the church.

One of the most important things in growing churches is to have continuous multiplication of small groups. Health seminars can be conducted in unreached areas; these will be an opening to the gospel; moreover prejudice can be avoided. A two-day church growth seminar can be conducted to motivate and empower the church through strategic church growth training. It will help to set goals for church growth.

\section{Conclusion}

In the light of this study, it is found that the implementation of appropriate strategies would help the churches grow. A pastor cannot do everything himself, but through efficient sharing of his responsibilities with others, he equips the laity for the ministry. The implementation of a lay training program will help each congregation to become involved in an active outreach program. The cell groups also will empower the church for witnessing. Another important principle of church growth is prayer. There should be intercessory prayer teams and prayer chains in each church. Worship services 
should be made more relevant. These strategies will be implemented in the three churches of Kottayam and, if successful, will be implemented in other churches also. Such strategies will eventually make the churches grow.

\section{$\underline{\text { Recommendations }}$}

To the North Kerala Section

At present in the North Kerala Section, each pastor takes care of two to three churches. He should delegate his responsibilities to the elders after training them. A training program should be conducted at the local church level, district level, and section level. The trainees should be evaluated later. Worship services should not be boring. The worship format used now is not appropriate to the local situation, so it should be simplified. Evaluate the worship services to find out whether they meet the needs of the worshipers. Moreover, conduct a two-day church growth seminar in all the churches by which the potential of the churches may be developed.

\section{To the Local Churches}

The churches should spend more time in prayer. Organize prayer bands, intercessory prayer teams, and prayer chains. Fix prayer request boxes in front of each church so that the public can drop in their prayer requests, and every Sabbath a prayer team can empty it and pray for the requests. Conduct revival meetings every year so that the inactive members can be brought back to the fellowship. Start cell-group ministries in all churches. The multiplication of cell groups will result in church growth. 
To the Southern Asia Division

Today due to the increase of diseases, vegetarianism has a tremendous influence in the society, so health seminars can be conducted in new areas with the help of the Rotary Clubs, Lions Clubs, YMCA, YWCA, and other social institutions. The Five-Day Plan also can be conducted along with the health seminars. This will help to find new areas and receptive people without any prejudice.

\section{To Spicer Memorial College}

Church growth studies should be a part of the curriculum of the theology students. Also, students should be trained to conduct church growth seminars, lay training programs, and health seminars. Practical knowledge of personal and public evangelism would help them be ready to meet the challenges in the field. 


\section{BIBLIOGRAPHY}

Ábbiss, G. G. "Training at Hebron." India Church Growth 2 (1989): 11-12.

Anderson, William K. The Minister and Human Relations. Nashville: General Conference Commission of the Methodist Church, 1943.

Arn, Win, and Donald McGavran. How to Grow a Church. Glendale: Regal,1973.

Arnold, Jeffrey. The Big Book on Small Groups. Wheaton, Illinois: InterVarsity, 1992.

Baburaj, Kottayam Jilla Directory. Kottayam: Jijo, 1997.

Bahadur, Raja. "Prayer Evangelism." India Church Growth 2 (1989): 1-2.

Barclay, William. The Daily Study Bible. Bangalore: Theological Publications in India, 1987.

Billy Graham Evangelistic Association. "Discipleship and Follow-up." India Church Growth 2 (1989): 7-9.

Chaney, Charles, and Ron Lewis. Design for Church Growth. Nashville: Broadman, 1997.

Couchman, Bob, and Win Couchman. Small Groups: Timber to Build Up God's House. Wheaton, Illinois: Harold Shaw, 1982.

Burrill, Russell. Revolution in the Church. Fallbrook, California: Hart Research Center, 1993.

Coleman, Lyman. Small Group Training Manual. Littleton, Colorado: Serendipity, 1991.

Dass, Kumar. "Extension Education for Church Multiplication." India Church Growth 1 (1984): 176.

Dudley, Roger L., and Des Cummings, Jr. Adventures in Church Growth. Hagerstown, Maryland: Review and Herald, 1983. 
George, O. J. "Kottayam Thriving as Publishing Capital of Kerala." The Indian Express, July $20,1996,7$.

George, T. C. "Pentecostal Church Growth in South India." India Church Growth 1 (1984): 135-139.

Gerber, Vergil. God's Way to Keep a Church Going and Growing. South Pasadena: William Carey, 1973.

Green, Michael. Evangelism Through the Local Church. London: Hodder and Stoughton, 1991.

Hagner, Donald A. Matthew. Word Biblical Commentary, vol. 33A. Dallas: Word, 1995.

Harnack, Adolf. The Expansion of Christianity in the First Three Centuries. Vol. 1. New York: Putnam's Sons, 1904.

Hedlund, Roger E. “Biblical Basis for Church Growth,” India Church Growth 1 (1984): 18.

- Building the Church. Madras: Evangelical Literature Service, 1982.

“Contextualized Protestant Missionary Training." India Church

Growth 1 (1984): 164-168.

. God and the Nations: Biblical Theology of Mission in the Asian

Context. Delhi: Indian Society for Promoting Christian Knowledge, 1997.

. "People Movements." India Church Growth 1 (1984): 65-67.

Henry, Matthew. Matthew Henry's Commentary. Edinburgh: Marshall Morgan and Scott, 1960.

Hohensee, Donald. Church Growth in Burundi. Pasadena: William Carey, 1939.

Jenson, Ron, and Jim Stevens. Dynamics of Church Growth. Grand Rapids: Baker Book, 1981.

John, M. M. “CMS Missionaries.” Kottayam Municipality Golden Jubilee Souvenir, 1971.

"Jottings from J. I. Packer's Sermon on Revival." India Church Growth 2 (1989): 218. 
Kelly, Balmer H., ed. The Book of Acts. Layman's Bible Commentary. Richmond, Virginia: John Knox, 1960.

“Korea: The First International Prayer Assembly." India Church Growth 2 (1989): 57, 59,64 .

Krishnan, G, ed.. A Peep into the History of Kottayam. Kottayam: Rohini Communications, 1997.

La Roe, Wilber. The Church We Love. New York: Abingdon, 1958.

Larom, Peter. Pastor: A Practical Guide for Church Leaders. Achimota, Ghana: Africa Christian, 1989.

Logan, Robert E. Beyond Church Growth. Grand Rapids: Fleming H. Revell, 1989.

Longkumer, Nuklu. The Growth of Baptist Churches Among the Aos of Nagaland. Changtongya: Changtongya Baptist Church, 1998.

Marshall, Howard I. The Book of Acts. The Tyndale New Testament Commentaries, vol. 5. Grand Rapids: Eerdmans, 1989.

Mathew, K. M., ed. Manorama Yearbook, 1994. Kottayam: Malayala Manorama, 1994.

McDormand, Thomas Bruce. The Art of Building Worship Services. Nashville: Broadman, 1958.

McGavran, Donald. Understanding Church Growth. Madras: Evangelical Literature Service, 1970.

Menon, A. Sreedhara. Kerala Districts Gazettes: Kottayam. Trivandrum: Kerala Gazettes, 1975.

Mizuki, John. The Growth of Japanese Churches in Brazil. Pasadena: William Carey, 1978.

Mott, John R. Liberating the Lay Forces of Christianity. New York: Macmillan, 1932.

Neighbour, Ralph W., Jr. The Shepherd's Guidebook. Houston: Touch, 1996.

Neill, Stephen. A History of Christian Missions. New York: Penguin, 1979.

Nelson, Marlin L. Principles of Church Growth. Bangalore: Acts Trust, 1995.

"News From Abroad." India Church Growth 1 (1984): 237. 
Patterson, George, and Richard Scoggins. Church Multiplication Guide. Pasadena: William Carey, 1993.

Peters, George W. A Theology of Church Growth. Grand Rapids: Zondervan, 1982.

Philip, Abraham. "House Churches." India Church Growth 1 (1984): 193-195.

Ponraj, S. D. The Grass Root Church Planter's Training Handbook. Madhupur: Mission Educational Books, 1996.

Pyarelal, V. B. District Handbooks of Kerala: Kottayam. Trivandrum: Department of Public Relations, 1995.

Reid, Clyde. Groups Alive--Church Alive: The Effective Use of Small Groups in the Local Church. New York: Harper and Row, 1969.

Robb, John D. Focus! The Power of People Group Thinking. Madhupur: Mission Educational Books, 1994.

Robertson, James D. Minister's Worship Handbook. Grand Rapids: Baker, 1974.

"The Role of Israel in Old Testament Prophecy." Seventh-day Adventist Bible Commentary. Edited by Francis D. Nichol. Rev. ed. Washington, D.C.: Review and Herald, 1980.

Sasi Bhooshan, M. G. "Kottayam Past, Present." The Indian Express, September 26, $1997,7$.

Schwarz, Christian A. Natural Church Development. Carol Stream: Church Smart Resources, 1996.

Selvaraj, M. D. “A CSI Church in Madras Is Growing.” India Church Growth 1 (1984): 204-205.

Sumitra, Sunand, and F. Hrang Hkuma, eds. Doing Mission in Context. Bangalore: Theological Book Trust, 1995.

Swanson, Allen J., ed. I Will Build My Church: Ten Case Studies of Church Growth in Taiwan. Taichung: Taiwan Church Growth Society, 1977.

Takatemjen, A. O. "Revival and the Nagaland Missionary Movement." India Church Growth 2 (1989): 215-217.

Taylor, Harold. Tend My Sheep. Southampton: SPCK, 1983. 
Tippett, A. R., ed. God, Man and Church Growth. Grand Rapids: Eerdmans, 1973.

Towns, Elmer L. An Inside Look at Ten of Today's Most Innovative Churches. Ventura: Regal, 1973.

Van Rheenen, Gailyn. Church Planting in Uganda: A Comparative Study. Pasadena: William Carey, 1976.

Wagner, C. Peter. Leading Your Church to Growth. Ventura: Regal, 1984.

Warren, Rick. The Purpose Driven Church. Grand Rapids: Zondervan, 1995.

Waymire, Bob. "Small Group Studies and Church Planting." India Church Growth 3 (1996): 5-7.

White, E. G. The Acts of the Apostles. Mountain View, California: Pacific Press, 1911. . Evangelism. Washington, D.C. : Review and Herald, 1946.

Yonggi Cho, Paul. "The Secret Behind the World's Biggest Church." India Church Growth 2 (1989): 130.

Zachariah, C. "The Present Growth of the Assemblies of God: Congregations in Tamil Nadu." India Church Growth 1 (1984): 277-279. . "Seven Growth Principles for India." India Church Growth 1 (1984): 97-99. 
Personal Family Background

Name

Place of Birth

Date of Birth

Home Address

Educational Background

College

Master of Arts in Religion

Doctor of Ministry

Work Experience

Pastor

Bible Teacher

Ministerial Director

Stewardship Director

Section Evangelist
Robinson Stephenson

Trivandrum, Kerala, India

November 11, 1954

SDA office, Moospet Road, Trichur, 680 005, Kerala

Spicer Memorial College, Ganeshkhind P.O., Aundh Road, Pune 411007 1980-1983

Andrews University, Spicer College 1991-1993

Andrews University, Spicer college 1996-2000

North Kerala Mission field 1974-1988

Lowry Memorial Junior College, Bangalore 1988-1993

North Kerala Section of SDA, Trichur 1993-1995

North Kerala Section of SDA, Trichur 1996-1998

North Kerala Section of SDA, Trichur 1998- 